\title{
ఇUSGS
}

\section{Public Acceptance of Management Actions and Judgments of Responsibility for the Wolves of the Southern Greater Yellowstone Area: Report to Grand Teton National Park}

By Jonathan G. Taylor, S. Shea Johnson, and Lori B. Shelby

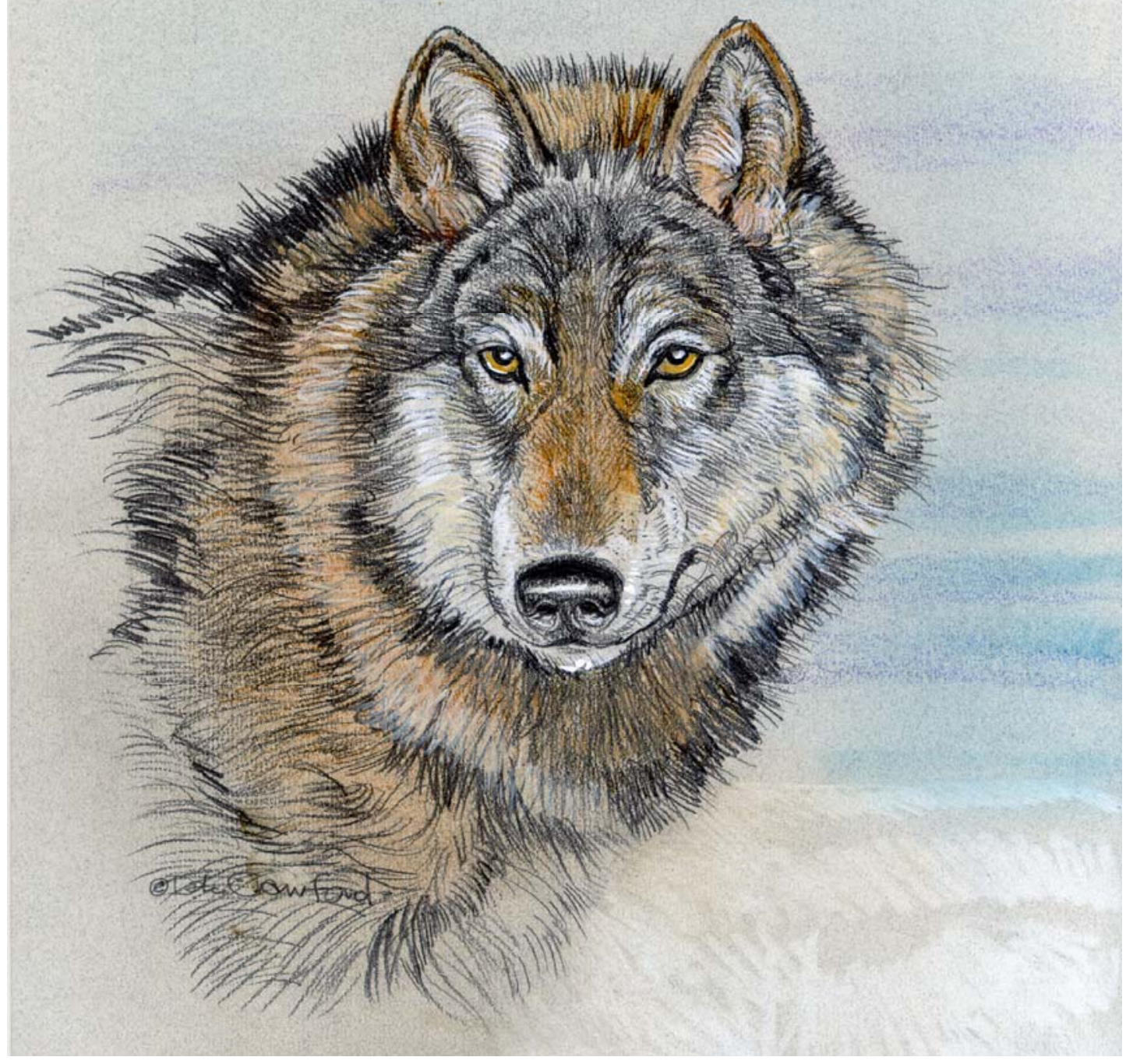

Open-File Report 2005-1408

U.S. Department of the Interior

U.S. Geological Survey 


\section{U.S. Department of the Interior \\ Gale A. Norton, Secretary}

\section{U.S. Geological Survey \\ P. Patrick Leahy, Acting Director}

\section{U.S. Geological Survey, Reston, Virginia 2005}

For product and ordering information:

World Wide Web: http://www.usgs.gov/pubprod

Telephone: 1-888-ASK-USGS

For more information on the USGS - the Federal source for science about the Earth, its natural and living resources, natural hazards, and the environment:

World Wide Web: http://www.usgs.gov

Telephone: 1-888-ASK-USGS

Suggested citation:

Taylor, J.G., Johnson, S.S., and Shelby, L.B., 2005, Public acceptance of management actions and judgments of responsibility for the wolves of the Southern Greater Yellowstone area: Report to Grand Teton National Park, U.S. Geological Survey, Biological Resources Discipline, Open-File Report 2005-1408, 79 p.

Any use of trade, product, or firm names is for descriptive purposes only and does not imply endorsement by the U.S. Government.

Although this report is in the public domain, permission must be secured from the individual copyright owners to reproduce any copyrighted material contained within this report.

Cover art courtesy of Dale Crawford. 


\section{Contents}

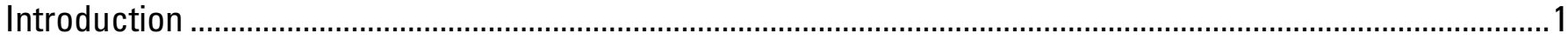

Wolves of Grand Teton National Park and the Greater Yellowstone Area ................................................. 1

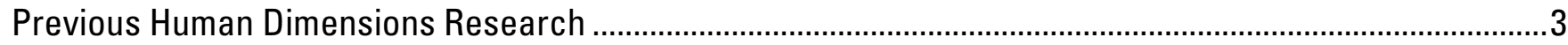

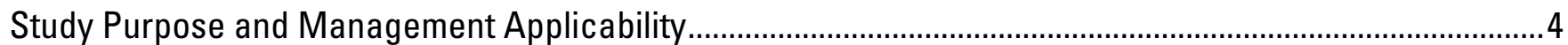

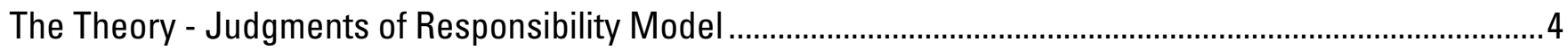

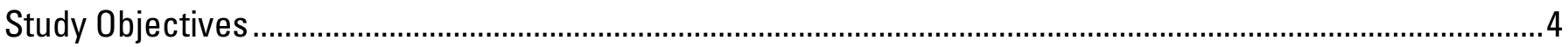

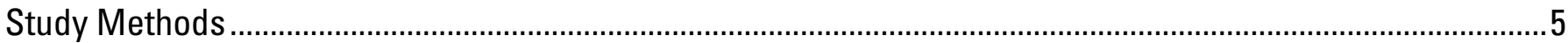

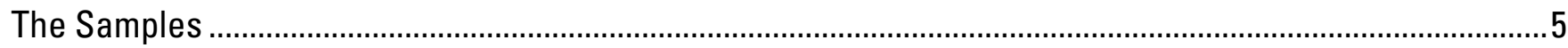

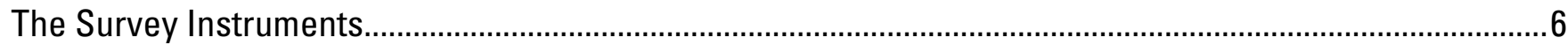

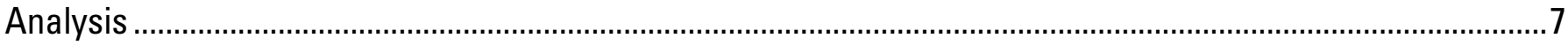

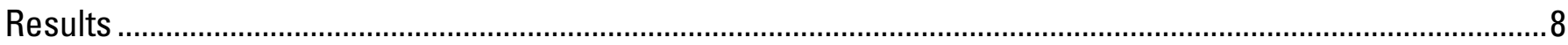

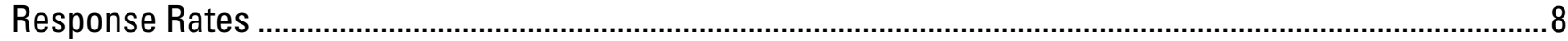

Demographics for the Two Population Samples ........................................................................................8

Judgments of Responsibility and Acceptance of Management Actions for Wolves .................................. 10

Judgments of Effectiveness of Wolf Management Actions .....................................................................19

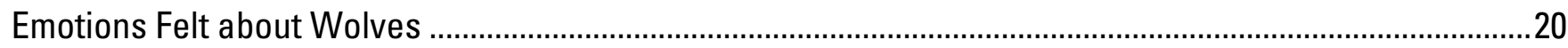

Experiences with Wolves: Personal and Potential...................................................................................23

Visitation and Experiences in Grand Teton National Park ........................................................................26

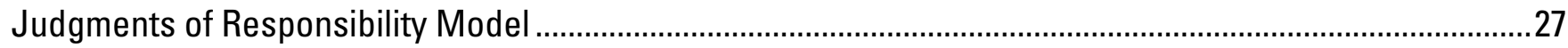

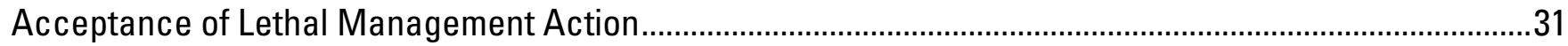

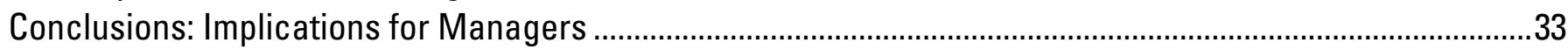

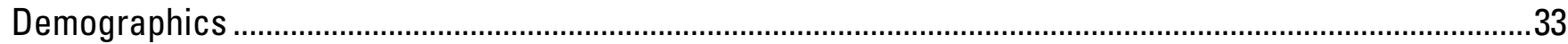

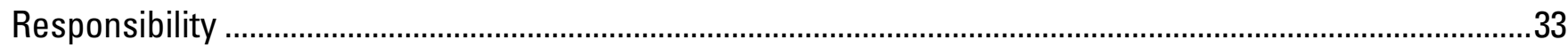

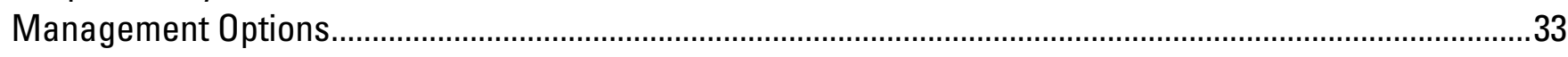

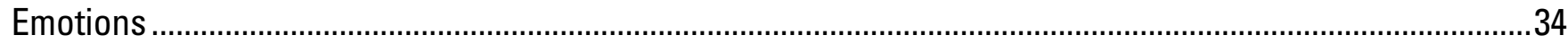

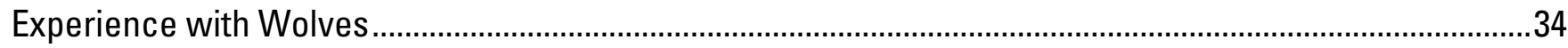

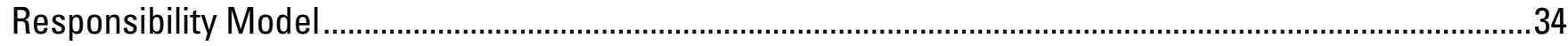

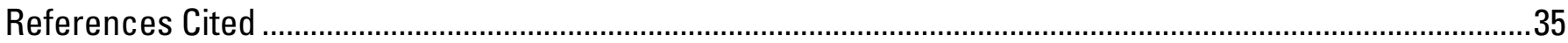

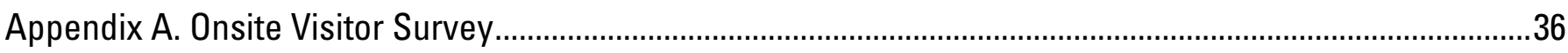

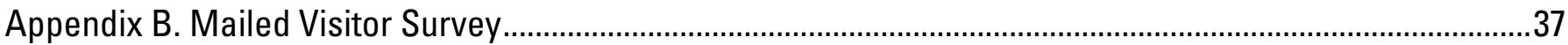

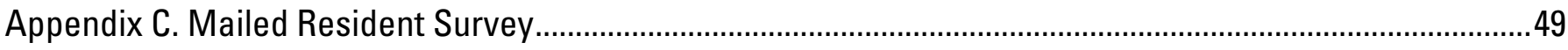

Appendix D. Reliability Results for Emotion Indices ..............................................................................61

Appendix E. Relationship between Judgments of Responsibility and Acceptance of Management Actions 63

Scenarios Involving Hiking Encounters in Grand Teton National Park ........................................................63

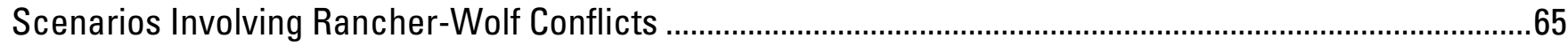

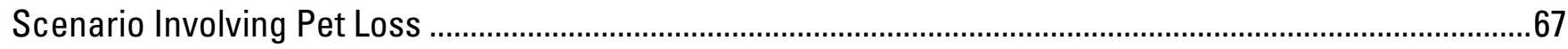

Appendix F. Relationship between Judgments of Responsibility and Emotion Indices ...................................68

Scenarios Involving Hiking Encounters in Grand Teton National Park .....................................................68

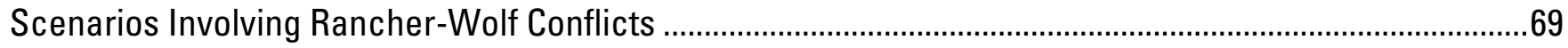

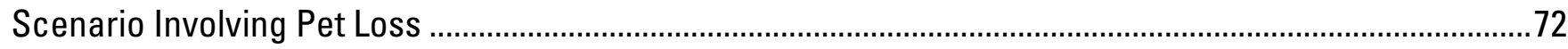

Appendix G. Relationship between Emotion Indices and Acceptance of Management Actions ....................73

Scenarios Involving Hiking Encounters in Grand Teton National Park ......................................................74 


\section{Figures}

1. Sampling area for resident survey ...........................................................................................................

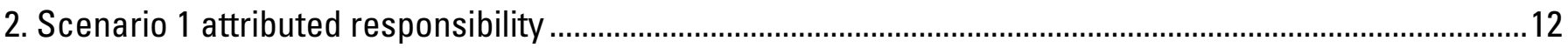

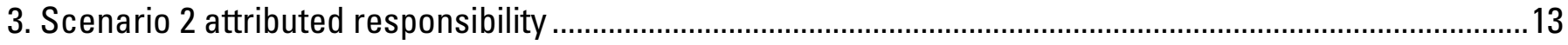

4. Scenario 3 attributed responsibility .................................................................................................... 14

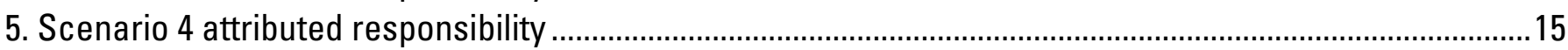

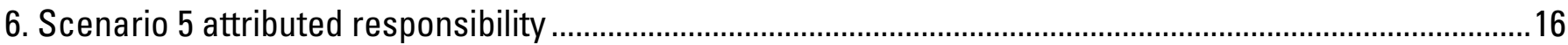

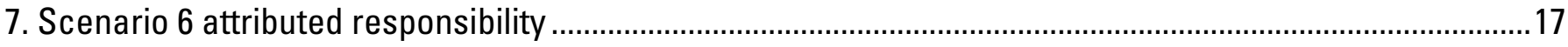

8. Average percent of responsibility assigned by residents and visitors to each of four possible agents involved in hypothetical human-wolf interaction, across six hypothetical scenarios ...............................18

9. Average quality of experience level for various hypothetical sightings of wolves in Grand Teton ..............25

10. Average quality of experience level for various hypothetical sightings of wolves on own land ................25

11. Judgments of responsibility conceptual model showing potential relationships among three variables included in the six hypothetical human-wolf interaction scenarios ........................................................28

12. Judgments of responsibility/emotions/management acceptance model for persons who hold the individual primarily responsible in human wolf encounters....................................................................3

13. Judgments of responsibility/emotions/management acceptance model for persons who hold agencies responsible in human wolf encounters

\section{Tables}

1. Wolf packs in and near Grand Teton National Park in 2003 and conflict information....................................

2. Description fo the six scenarios depicting possible human-wolf encounters...............................................

3. Demographic data: Local residents; census; park visitors.......................................................................

4. Mean acceptability ratings for five management actions following a hypothetical hiking-trail human-wolf

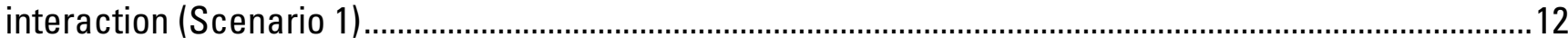

5. Mean acceptability ratings for six management actions following a hypothetical cattle-wolf interaction

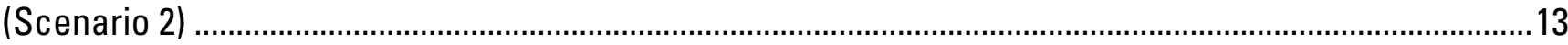

6. Mean acceptability ratings for four management actions following a hypothetical cattle-wolf interaction

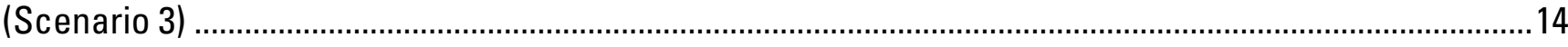

7. Mean acceptability ratings for four management actions following a hypothetical pet-wolf interaction (Scenario 4)

8. Mean acceptability ratings for five management actions following a hypothetical hiking trail-wolf interaction (Scenario 5).

9. Mean acceptability ratings for six management actions following a hypothetical cattle-wolf interaction (Scenario 6)

10. Cross-tabulation of wolf kill-norm with resident and visitor samples

11. Mean ratings of resident and visitor perceptions of management action effectiveness to alleviate human-wolf conflicts 
12. Local resident and park visitor overall responses to the aggregated emotion indices

13. Local resident and park visitor emotions toward wolves and their management in and around Grand Teton National Park .22

14. Local resident and park visitor self-reported personal and knowledge levels about wolves 23

15. Average experience ratings for tolerable numbers of encounters with wolves; local residents and park visitors 24

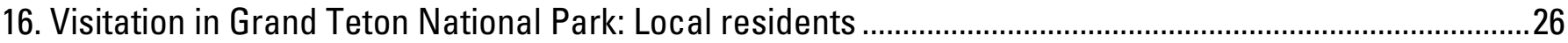

17. Visitation in Grand Teton National Park: Park visitors..................................................................................26

18. Local resident and park visitor's activities while in Grand Teton National Park..........................................27

19. Wolf-kill norm compared with aggregate emotion classes ......................................................................32

20. Demographic variables compared with wolf-kill norm ...........................................................................32

D-1. Reliability analysis of emotion indices pertaining to human-wolf interactions ........................................61

E-1. Correlations of proportional judgments of responsibility with acceptance of management actions for Scenario one

E-2. Correlations of proportional judgments of responsibility with acceptance of management actions for Scenario five 64

E-3. Correlations of proportional judgments of responsibility with acceptance of management actions for Scenario two

E-4. Correlations of proportional judgments of responsibility with acceptance of management actions for Scenario three

E-5. Correlations of proportional judgments of responsibility with acceptance for management actions for Scenario six. 66

E-6. Correlations of proportional judgments of responsibility with acceptance of management actions for Scenario four.

F-1. Correlations of three emotion indices with proportional judgments of responsibility for Scenario one..69

F-2. Correlations of three emotion indices with proportional judgments of responsibility for Scenario five..69

F-3. Correlations of four emotion indices with proportional judgments of responsibility for Scenario two ....70

F-4. Correlations of four emotion indices with proportional judgments of responsibility for Scenario three .71

F-5. Correlations of four emotion indices with proportional judgments of responsibility for Scenario six.......71

F-6. Correlations of three emotion indices with proportional judgments of responsibility for Scenario four 72

G-1. Correlations of three emotion indices with acceptance of management actions for Scenario one .......74

G-2. Correlations of three emotion indices with acceptance of management actions for Scenario five........75

G-3. Correlations of four emotion indices with acceptance of management actions for Scenario two..........76

G-4. Correlations of four emotion indices with acceptance of management actions for Scenario three .......77

G-5. Correlations of four emotion indices with acceptance of management actions for Scenario six ...........78

G-6. Correlations of three emotion indices with acceptance of management actions for Scenario four .......79 



\title{
Public Acceptance of Management Actions and Judgments of Responsibility for the Wolves of the Southern Greater Yellowstone Area: Report to Grand Teton National Park
}

\author{
By Jonathan G. Taylor, S. Shea Johnson, and Lori B. Shelby
}

\section{Introduction}

\section{Wolves of Grand Teton National Park and the Greater Yellowstone Area}

Gray wolves (Canis lupus) appeared in Grand Teton National Park (GRTE) in October of 1998, two years after being reintroduced to Yellowstone National Park (YNP). Since that time, five packs have been within the GRTE borders - Gros Ventre Pack, Nez Perce Pack, Yellowstone Delta Pack, Teton Pack, and Green River Pack (Table 1). Wolves in the Greater Yellowstone Area are increasing and spreading out geographically (USFWS and others, 2004). This dispersion was demonstrated recently by the death of a 2-year-old female wolf from the Swan Lake pack on I-70 in Colorado (June 7, 2004; http://mountain-prairie.USFWS.gov/pressrel 104-43.htm).

The organization of wolf packs in the GYA is dynamic and highly structured. In 2003, for example, a wolf from the Teton Pack joined with the Green River Pack, and several young wolves left the Teton Pack and moved south (USFWS and others, 2004). Pack size (averaging five to ten members) is dependent on hunting efficiency, which depends on prey size, type, and density. Each pack defends home ranges of several hundred square miles. The social structure of the pack is based on a breeding pair (an alpha male and female). Other wolves in the pack can be categorized as betas (males and/or females second in rank to the alphas), subordinates, pups, and occasional omegas (outcasts). Because generally only the alpha pair breeds, subordinate wolves of reproductive age must disperse from their packs and form new associations in order to breed. (http://www.nps.gov/grte/wolf/biolo.htm).

The reintroduced wolves are classified by the U.S. Fish and Wildlife Service (USFWS) as "nonessential experimental" under section 10(j) of the Endangered Species Act. The recovery criteria for the GYA wolves were met in 2002 for removing the wolves from the Endangered Species List (30 or more breeding pairs). Currently, the USFWS manages wolf populations in the GYA until delisting occurs. After delisting, state Fish and Wildlife Services in Montana, Idaho, and Wyoming will be responsible for managing wolves. Each state must submit a wolf management plan to the USFWS which then must be approved before management shifts occur. As of this writing, the process of delisting the wolves in the state of Wyoming is ongoing. However, the reclassification of wolves nationwide was completed on April 1, 2003. Wolves outside of YNP changed in status from endangered to threatened. The wolves classified in the experimental nonessential population did not change in status (USFWS and others, 2004). 
This classification of experimental nonessential population allows for flexibility in management decisions concerning the wolves (Smith and others, 2004). For example, control actions in the GYA included trapping and radio-collaring four wolves; intensive monitoring; increasing riders on grazing allotments; harassing wolves with rubber bullets, cracker shells, and lights; moving livestock to different pastures; and issuing four shoot on-sight permits. When non-lethal control methods were not effective, wolves were killed in an attempt to prevent further livestock depredations (USFWS and others, 2004; Table 1).

At the same time that wolf numbers are rising, human population statistics in the GRTE area are also rising. The population of Teton County, Wyoming in 1990 was just over 11,000 people; today that number has increased to approximately 19,000 (U.S. Census Bureau, 2005). park visitation for GRTE has been substantial over the last several years with an average visitation of 2.5 million visitors (NPS, 2004a). Furthermore, land ownership surrounding GRTE and the establishment of grazing rights within park boundaries are problem areas for wolf-human interactions due to livestock depredation. With increasing numbers of visitors, residents, and livestock it is reasonable to assume that conflicts are going to increase also.

Table 1. Wolf packs in and near Grand Teton National Park in 2003 and conflict information. ${ }^{a}$

\begin{tabular}{|c|c|c|c|c|}
\hline Pack name & Location & Pack size (2003) & Depredation & $\begin{array}{l}\text { Management } \\
\text { actions }\end{array}$ \\
\hline Nez Perce $^{b}$ & $\begin{array}{l}\text { YNP - Travels } \\
\text { extensively }\end{array}$ & & $\begin{array}{l}1 \text { cow confirmed - } \\
2003\end{array}$ & \\
\hline Yellowstone Delta & $\begin{array}{l}\text { YNP and Bridger- } \\
\text { Teton Wilderness }\end{array}$ & & & \\
\hline Teton & $\begin{array}{l}\text { GRTE and Gros } \\
\text { Ventre River drainage }\end{array}$ & $12-14$ & 1 cow confirmed & 0 wolves killed \\
\hline Green River & Green River Basin & 3 & $\begin{array}{l}9 \text { cattle confirmed } \\
1 \text { sheep confirmed } \\
\text { Several other probable } \\
\text { kills - } 2003\end{array}$ & 3 wolves killed \\
\hline Non-packs ${ }^{\mathrm{c}}$ & $\begin{array}{l}\text { Upper Green River } \\
\text { drainage } \\
\text { South of GRTE } \\
\text { Near Cora } \\
\text { Big Piney }\end{array}$ & $\begin{array}{l}2 \\
3-4 \\
3 \\
2-3\end{array}$ & unknown & 5 wolves killed \\
\hline $\begin{array}{l}\text { Greater Yellowstone } \\
\text { Area totals }\end{array}$ & & 301 wolves & $\begin{array}{l}64 \text { cattle }^{\mathrm{d}} \\
211 \text { sheep }^{\mathrm{d}} \\
6 \text { dogs }^{\mathrm{d}} \\
10 \text { goats }^{\mathrm{d}}\end{array}$ & $\begin{array}{l}59 \text { wolves killed. } \\
\text { No wolves } \\
\text { translocated. }\end{array}$ \\
\hline Wyoming totals & & 234 wolves & $\begin{array}{l}30 \text { cattle }^{\mathrm{e}} \\
36 \text { sheep }^{\mathrm{e}} \\
10 \text { goats }^{\mathrm{e}} \\
2 \text { horses }- \text { injured }^{\mathrm{e}}\end{array}$ & 18 wolves killed \\
\hline
\end{tabular}

anformation from Smith and others, (2004); USFWS, NPT, NPS, and USDA, 2004 representing 2003 data.

${ }^{\mathrm{b}} \mathrm{A}$ Yellowstone National Park pack that travels extensively.

${ }^{\mathrm{c}}$ These wolves are in small groups that have not produced pups. The social structure of a pack is based on a breeding pair.

${ }^{\mathrm{d}}$ Livestock numbers reflect confirmed depredations since wolves were reintroduced.

${ }^{e}$ Livestock numbers reflect confirmed and probable depredations since wolves were reintroduced. 
In 1950, GRTE was expanded to include Jackson Hole National Monument, making the entire park 310,000 acres. Park expansion was not an easy acquisition as local ranchers feared losing valuable grazing land. Because of the intense controversy, a provision was included that protected existing grazing rights within the new park boundaries. Unlike other national parks these grazing rights are still protected today. Livestock grazing is allowed within park boundaries as well as on the surrounding Teton National Forest. In GRTE in 2004, 1,800 cows and horses were permitted to graze on 36,000 acres. Livestock grazing on public land, coupled with wolves ranging out of the park to hunt, increase the likelihood of wolf-livestock interactions. In fact, livestock and wolf conflicts are on the rise in the GYA. Livestock depredations by wolves within Wyoming but outside of YNP nearly doubled in 2003 (51 vs. 27 in 2002). Depredations within GYA resulted in the deaths of 45 cattle, 90 sheep, and 10 goats for the year 2003 (USFWS and others, 2004). In 2002, 33 cattle, 71 sheep, and 1 dog were killed by wolves in GYA (USFWS and others, 2004). The USFWS responded to these depredations by killing 23 wolves in 2002 and 38 wolves in 2003 (see Table 1 for more data) (USFWS and others, 2004). In addition, 66\% $(n=57)$ of depredations were documented on public grazing allotments and $34 \%$ on private property (USFWS and others, 2004). Although wolves may use park areas for denning, many will travel to find food. Wolves disperse and roam long distances to hunt, so many depredations are occurring outside of park boundaries as well as on public grazing allotments.

Closing portions of trails located near denning sites can be an important management issue during the denning season. In the GYA, wolves generally breed in February and give birth in late April after a gestation period of about 63 days. At this time wolves are especially sensitive to human disturbance in the area around their den sites. The alpha female usually remains with the pups at the den site, while the other pack members are responsible for bringing food back to the den. When the pups are approximately two months of age, they are moved to an outdoor nursery. By October, the pups are usually traveling and hunting with the rest of their pack (http://www.nps.gov/grte/wolf/biolo.htm).

In the length of time that wolves have reinhabited GRTE, there has not been enough time for managers to predict the types of conflicts that may occur as the result of their introduction. There were six suspected illegal killings in 2003 that are under investigation (USFWS and others, 2004). Some issues were not predicted as problems, but monitoring has shown conflicts. For example, monitoring data from 1997 in Minnesota suggests that wolves do not use frozen ponds in the presence of snowmobiles (Schaberl, 1998). Also, elk have been displaced and gathered in large numbers on private property and elk crowding on specific feeding grounds because of wolf presence on others has become an issue (USFWS and others, 2004).

\section{Previous Human Dimensions Research}

In general, past human dimensions research on public attitudes toward wolves and their reintroduction has shed light on the multi-dimensionality of issues surrounding the wolf. Conservation and management efforts can benefit from understanding human dimensions research on public knowledge, opinions, and sentiment. Research in wolf ecology alone will not determine the fate of wolves in the United States; public attitudes and actions will ultimately decide the future of wolf conservation efforts. These studies have alluded to the polarization between specific groups of the public, misconceptions about wolves, and proximity to wolves as key factors affecting attitudes towards wolves and their conservation. Human dimensions research on wolf management has also shown that cognitive factors such as beliefs and value orientations strongly influence an individual's support for wolf reintroduction programs (Cromley, 1997; Brown-Nuñez and Taylor, 2002). 


\section{Study Purpose and Management Applicability}

Does GRTE provide unique challenges for the management of wolves? Most of the human dimensions research on wolves in the GYA has been conducted in relation to YNP. Grand Teton National Park has a different historical and legislative background than YNP, primarily distinguished by the allotment of grazing rights within the park. Livestock grazing in the Teton Park creates a different dynamic in wolf-human conflict than in other park jurisdictions, such as YNP. As a result, will the opinions of people be different in and around GRTE? In addition, much is known about the attitudes of people towards wolves and wolf reintroduction (Brown-Nuñez and Taylor, 2002). However, the question of how people attribute responsibility about wolves has gone unanswered. The purpose of this study is to examine the attribution of responsibility about wolves and compare those results with demographics, emotions about wolves, and acceptability of various management actions in and near GRTE.

The research was conducted in late summer/early fall 2003 by the Policy Analysis and Science Assistance [PASA] Science Program/Fort Collins Science Center/U.S. Geological Survey in collaboration with GRTE personnel.

\section{The Theory-Judgments of Responsibility Model}

Judgments of responsibility associated with conflict situations with wolves can be better understood by applying attribution theory from the field of social psychology. Attribution theory describes the way in which people explain the causes of their own and other people's behavior. The theory can be viewed as a framework for understanding the rules that individuals use when trying to determine cause and effect in everyday life. Attributions provide a mechanism for controlling events and predicting future occurrences (Weiner, 1995). Central to forming attributions are the emotions involved when an individual tries to determine who or what is responsible for a situation. Also key to the attribution process are the outcomes or attitudes about what actions should remedy any problem that resulted from the particular situation. These three components - judgments of responsibility, emotions felt, and actions taken to correct a situation are essential to the attribution process and interact in the human mind when we encounter life situations that have cause and effect components.

Research on the attribution process, in particular judgments of responsibility, can help answer questions stakeholders may generate following human-wildlife conflict situations: Who or what is responsible for the event that occurred and how should subsequent management action be directed? The applicability of judgments of responsibility research to human-wildlife conflicts is discussed Harlow (2001). Knowledge of how stakeholders in the area surrounding GRTE (park visitors and local residents) form judgments of responsibility following potentially negative encounters with wolves can assist managers in choosing and implementing actions to remedy such situations.

\section{Study Objectives}

This study focused on Jackson-Hole area residents' and GRTE visitors' judgments of responsibility, acceptance of management actions, and emotional factor related to GYA wolves. The study objectives were to:

1. assess both residents' and park visitors' judgments of responsibility [i.e., person involved, GRTE, USFWS, Wyoming Department of Game and Fish (WYG\&F)] pertaining to human-wolf conflict situations,

2. determine the level of acceptance of current and potential wolf management practices and attitudes towards Southern GYA wolf management practices, 
3. assess the emotions that affect both residents and visitors in their judgments about wolves and wolf management,

4. determine how judgments of responsibility, stakeholder acceptance of management actions directed at the wolves, and emotions interact, and

5. examine the socio-demographic data for residents and park visitors.

\section{Study Methods}

\section{The Samples}

Independent samples were collected to represent the local resident and park visitor populations. For the local resident survey, a randomly selected list of residents located within a 100-mile radius of Jackson, Wyoming was obtained from Survey Sampling, Inc. (Figure 1). All surveying was conducted during the summer of 2003, so both samples have a degree of seasonal bias. Summer is the time of the highest occupation of part-time residences, and is also the time of year when the majority of visitors come to the park. This sample does omit winter part-time residents (e.g. skiers) and winter visitors, for example, who come to see the concentration of elk in the nearby National Elk Refuge.

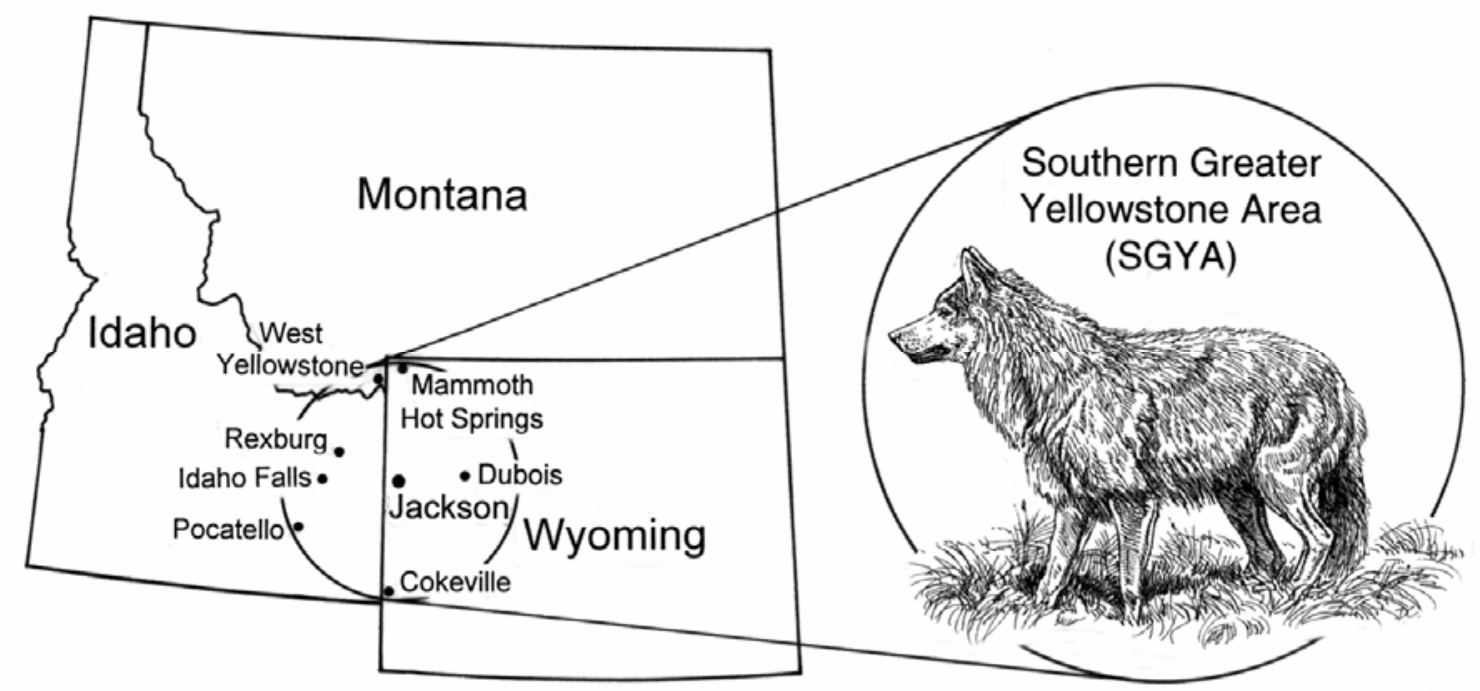

Artwork by Dale Crawford

Figure 1. Sampling area for resident survey.

Park visitors were surveyed by intercept interview (see Appendix A for specific questions), to collect basic information and addresses for a follow-up mail survey. Intercept locations were determined in collaboration with GRTE staff to sample the variety of different ways in which people use the park: drive-through visitors, campers, and trail hikers. The followup park visitor survey was mailed to those park visitors who agreed to participate, with the exception of a small number of respondents who requested a copy of the survey during the intercept interview at the park. An adapted Dillman (2000) method was used with both the local resident and park visitor surveys by sending a thank you/reminder post card and, subsequently, a follow-up letter with a second survey to those who had not yet responded. The local resident area has a census-reported population of 243,000 residents; the GRTE reports annual visitation of 2.5 million persons. To extrapolate to the larger population-at-interest would require weighing the visitor results by a factor of 10 . 


\section{The Survey Instruments}

The visitor survey instrument (Appendix B) and the local resident survey instrument (Appendix C) were divided into five distinct sections. Sections 1-3 are identical for both the local resident and the visitor surveys. A general description of each section is given below.

\section{Section 1. Public Attribution of Responsibility in Hypothetical Situations and Acceptance of Management Actions}

Six different hypothetical situations depicting possible human-wolf encounters were described to respondents in the first section of the survey (see Table 2 for details). The purpose of these scenarios was to allow the respondents to judge who they felt to be responsible for the stated conflict or potential conflict between humans and wolves described in each scenario. Factors that might affect assignments of responsibility were varied among the scenarios, including: the location of the encounter (on park property or private land); the type of encounter (e.g., hikers seeing wolves on trail, wolves harassing cattle, or pets and cattle being depredated by wolves); and the endangered species status of the wolves (listed as "endangered experimental population" or as delisted). These factors were determined through consultation with park managers.

Respondents were given the choice of five possible agents [the individual experiencing the encounter, GRTE, the WYG\&F, and the USFWS] plus one open-ended 'other' option, to whom they could assign portions of responsibility. These survey scenario items were designed to guide respondents to enter percentages of responsibility that would total to $100 \%$ within each scenario. Following the attribution of responsibility, respondents were asked to rate the acceptability of several management options listed to possibly remedy or prevent the conflict in the hypothetical situation. Acceptance of management actions were coded on a 7-point Likerttype scale ranging from 1 = 'highly unacceptable' to 7 = 'highly acceptable'.

Table 2. Description of the six scenarios depicting possible human-wolf encounters.

\begin{tabular}{llll}
\hline Scenario \# & Status of wolves & Encounter type & Location of encounter \\
\hline 1 & Endangered, experimental population & Wolves feeding near trail & In GRTE \\
2 & Endangered, experimental population & Wolves chase cattle & In GRTE \\
3 & Endangered, experimental population & Wolves kill cattle & On private land \\
4 & Delisted & Pet killed by wolves & On private land \\
5 & Delisted & Wolves denning near trail & In GRTE \\
6 & Delisted & Wolves kill cattle & In GRTE \\
\hline
\end{tabular}

\section{Section 2. Effectiveness of Management Options}

Eleven items were used to measure respondents' judgments of the effectiveness of various management options in remedying conflicts between wolves and human activities or property. Management options given for respondents to evaluate ranged from non-lethal techniques (i.e. frightening devices), preventive measures (i.e. closure of areas), and capture and relocation of wolves, to the most invasive measure of destroying problem wolves. Effectiveness of management actions were rated on a 7-point Likert scale from $1=$ 'highly unacceptable' to 7 = 'highly acceptable'; the midpoint, 4 , was labeled 'no opinion.' 


\section{Section 3. Emotions Towards Wolves}

Seventeen items assessing different emotions about wolves and potential human-wolf interactions were asked of all respondents. These items allowed for the investigation of such emotions as fear of wolves, anger felt about the presence of wolves, sympathy for wolves, and sympathy felt for those negatively affected by wolves. Survey respondents were asked to rate their level of agreement with each of the emotion items. The items were coded on a 5-point Likert-type scale ranging from 1 = 'strongly disagree' to $5=$ 'strongly agree', plus a 'don't know' response option.

\section{Section 4. Experience with Wolves}

Respondents were also asked to report their personal experiences with wolf sightings and to rate potential experiences of seeing wolves in varying numbers, frequencies, and settings. Respondents evaluated a series of hypothetical experiences involving lone wolves and/or wolf packs in the park or on private property. The type of experience was coded on a 7-point Likerttype scale ranging from 1 = 'extremely positive' to 7 = 'extremely negative', again with a 'don't know' option.

The local resident survey instrument had three additional questions in Section 4 to determine personal experiences with wolves (Appendix C). These questions were also asked of park visitors during the intercept interview at the park (Appendix A). The items included the number of times wolves were seen in the wild and in GRTE. In addition, residents were asked their perceived knowledge level about wolves. A respondent's perceived knowledge about wolves was measured on a 5-point scale ranging from, $1=$ 'not at all knowledgeable' to $5=$ 'very knowledgeable'.

\section{Section 5. Experiences in Grand Teton National Park and Demographics}

Respondents' experiences in GRTE were measured by the number of visits to GRTE, length of stay, activities participated in during their visit, and lodging type. Respondents were asked socio-demographic questions, including age, sex, ethnicity, race, education, income, and resident community type. There are minor differences between the visitor and local resident survey instruments in Section 5 (see Appendix B and C for details). For example, visitors were asked what activities they participated in during this visit; while residents were asked what activities they participated in during their last visit to the park.

\section{Analysis}

Data were analyzed using SPSS version 11.5. Data for the two samples (local residents and park visitors) were analyzed comparatively for each of four general conceptual areas:

1. judgments of responsibility in varying human-wolf encounter situations,

2. acceptance of management actions for wolves in these situations,

3. experience with wolves, both past and potential, and

4. emotions felt about wolves.

In addition to these conceptually defined components of the survey, demographic, and general descriptive information about park use were assessed. Analysis techniques were primarily limited to basic descriptive statistics including frequencies and percentage crosscomparisons. Comparative statistical tests included chi-square tests, t-tests, repeated measures ANOVA, and bi-variate correlations. 
When a series of t-tests of the means of three or more groups are conducted on related items, there is a risk of violating independence assumptions; use of a Bonferroni correction eliminates this possibility (Neter and others, 1996). When a series of t-tests were conducted for these analyses (e.g., when differentiating between average acceptability ratings for each of the possible management actions given), a Bonferroni correction was used. For a Bonferroni correction, $p<.05$ is divided by the number of tests run to determine a corrected $p$-value. Regular ANOVA also has independence assumptions. In order to compare judgments of responsibility within the six hypothetical scenarios, repeated measure ANOVA was used since the use of six scenarios with similar lists of items violates the independence assumptions of a regular ANOVA.

\section{Results}

\section{Response Rates}

For the local resident survey, 1,297 surveys were mailed to residents, but 120 were returned by the Postal Service as "undeliverable." Local residents returned 604 surveys for a response rate of 51\%. A follow-up phone survey was conducted to determine if the nonresponding residents deviated from the residents who returned the surveys, either demographically or in wolf-experience. The follow-up telephone study succeeded in collecting data from $10 \%$ of the non-respondents. Of the half that were not successfully interviewed, twothirds (64\%) were unreachable (disconnected or wrong number) and one third (36\%) again refused to answer questions about wolves in the GRTE area. Chi-square comparisons of crosstabulated variables of respondent vs. non-respondent interviewees showed no significant demographic differences for age, sex, education, income, or size of resident community. Experience with wolves, both within Grand Teton and in general, also showed no significant differences. Only in self-assessed knowledge about wolves did respondents show a significantly higher level than non-respondents, (mean responses were 3.1 and 2.4, respectively, on a 5-point Likert-type scale, $p<.05$ ).

The park visitor survey yielded a response rate of 81\%: 748 surveys were mailed, 11 were undeliverable, and 596 were filled out and returned. A total of 1,200 surveys were used in this analysis. These samples provide estimates at the $95 \%$ confidence interval for each of these two populations. The results reported were considered to be representative of park-visitors and of the resident population who consider themselves more knowledgeable about wolves. How the samples differ from local and national census is discussed in the next section.

\section{Demographics for the Two Population Samples}

The proportion of males completing the local resident survey $(72 \%)$ was greater than for the park visitor sample (55\%); but in both instances, greater than the census percentage (see Table 3). The two groups were similar to one another in age, ethnicity, and race composition, but the resident sample was low in American Indian participation, and the proportion of European Americans was higher than the national average for both samples. Park visitors reported higher overall completed education than local residents (e.g. 68\% PV reported achieving a college or an advanced degree, compared to $41 \%$ LR); and visitors certainly exceeded the national average in higher education. Local residents reported earning a somewhat lower approximate annual household income than park visitors, whose income was also quite a bit higher than the national average (LR median income $=\$ 50,000-75,000, \mathrm{PV}$ median income $=\$ 75,000-100,000)$. The regional census median income varied greatly, over $\$ 20,000$ between Teton County, Wyoming at $\$ 55,000$ and several of the more rural counties with average annual incomes in the low 30's. 
Regarding "current resident community," the majority of local residents lived in communities of 50,000 or less while the majority of park visitors lived in cities of 50,000 or more. This difference is certainly predictable since only two communities in the local radius, Idaho Falls and Pocatello, have populations over 50,000 (Census.gov).

Table 3. Demographic data: Local residents; census; park visitors.

\begin{tabular}{|c|c|c|c|c|}
\hline \multirow[b]{2}{*}{ Socio-economic items } & \multirow[b]{2}{*}{ Local resident (\%) } & \multicolumn{2}{|c|}{ Census data $\left.{ }^{\mathrm{a}} \%\right)$} & \multirow[b]{2}{*}{ Park visitor (\%) } \\
\hline & & Regional & National & \\
\hline \multicolumn{5}{|l|}{ Gender } \\
\hline Male & 72 & 50 & 50 & 55 \\
\hline Female & 28 & 50 & 50 & 45 \\
\hline \multicolumn{5}{|l|}{ Ethnicity } \\
\hline Hispanic & 6 & 6 & 13 & 3 \\
\hline \multicolumn{5}{|l|}{$\operatorname{Race}^{\mathrm{b}}$} \\
\hline American Indian or Alaska Native & 1 & 3 & 1 & 1 \\
\hline White & 98 & 91 & 75 & 97 \\
\hline \multicolumn{5}{|l|}{ Education } \\
\hline Less than high school diploma & 2 & & & 1 \\
\hline High school diploma or GED & 19 & 87 & 80 & 8 \\
\hline Technical/vocational degree & 12 & & & 5 \\
\hline Some college & 26 & & & 18 \\
\hline 4 year college degree & 21 & 26 & 24 & 31 \\
\hline Advanced degree beyond college & 20 & & & 37 \\
\hline \multicolumn{5}{|l|}{ Annual household income before taxes } \\
\hline$\$ 10,000$ to $\$ 24,999$ & 9 & & & 4 \\
\hline$\$ 25,000$ to $\$ 49,999$ & 33 & & & 19 \\
\hline$\$ 50,000$ to $\$ 74,999$ & 27 & & & 21 \\
\hline$\$ 75,000$ to $\$ 99,000$ & 13 & & & 22 \\
\hline$\$ 100,000$ to $\$ 124,999$ & 9 & & & 13 \\
\hline$\$ 125,000$ or more & 7 & & & 19 \\
\hline Median Income & $\$ 50 \mathrm{~K}$ & $\$ 43.7 \mathrm{~K}$ & $\$ 42 \mathrm{~K}$ & $\$ 75 \mathrm{~K}$ \\
\hline \multicolumn{5}{|l|}{ Current residence or community } \\
\hline City with 250,000 or more people & $\mathrm{NA}^{\mathrm{c}}$ & & & 27 \\
\hline City with 100,000 to 249,999 people & NA & & & 13 \\
\hline Small city - 50,000 to 99,999 people & 41 & & & 12 \\
\hline Town with 10,000 to 49,999 people & 18 & & & 22 \\
\hline Small town/village $<10,000$ people & 24 & & & 15 \\
\hline Farm or rural area & 17 & & & 12 \\
\hline Average age & 53 years & & & 48 years \\
\hline
\end{tabular}

${ }^{\mathrm{a}}$ From http://quickfacts.census.gov/ - for 9-county region of WY/ID and for the nation.

${ }^{b}$ For local residents, $n=567$ for white and $n=17$ for all other races. For park visitors, $n=558$ for white and $n=16$ for all other races.

${ }^{\mathrm{c}}$ Not asked. No cities greater than 100,000 in population exist within a 100 mile radius of Jackson, Wyoming. 


\title{
Judgments of Responsibility and Acceptance of Management Actions for Wolves
}

\author{
Judgments of Responsibility
}

For the six scenarios provided, average percentages of responsibility were calculated for each of the potentially responsible agents from estimates given by the two samples: local residents and GRTE visitors (Figures 2 through 7). Again these were hypothetical scenarios involving human-wolf conflicts where factors affecting judgments of responsibility were varied across scenarios. Variables included location of the encounter (in the park or outside its boundaries); type of encounter (depredation or a siting near a trail); plus endangered versus delisted species status (see Table 2).

These scenarios, and the following discussion, are complex. To assure clarity, this would be an explanation of Scenario 2 findings (Figure 3, Table 5, page 13): Wolves have been harassing cattle on a grazing allotment within the park. Local residents consider this situation to be primarily the responsibility of the U.S. Fish and Wildlife Service (35\%) followed by the rancher involved (26\%), whereas the park visitors held the rancher as most responsible (41\%), the park next $(25 \%)$, and then the FWS (22\%). In terms of management actions, residents felt monitoring, capture and release, and frightening the wolves off were the more acceptable actions. Visitors also felt monitoring or frightening the wolves were acceptable, but they were in favor of moving the cattle away from the trouble site. However, the two samples differed significantly on every management action, especially on whether the wolves should be destroyed.

Overall, park visitors [PV] assigned the highest levels of responsibility to the individual involved in the encounter (43\% overall), especially for Scenarios 1 and 5 where the encounters involved hikers on trails within the GRTE (65\% and 48\% respectively: see Figures 2 and 6). The second highest levels of responsibility assigned by visitors to the individual involved were for scenarios depicting wolves harassing or killing cattle on grazing allotments within the park (41\% and 40\%, Scenarios 2 and 6 respectively: Figures 3 and 7). The only scenario for which visitors, on average, did not rate the individual as the primary responsible party was Scenario 3 (Figure 4) which depicted wolf predation of cattle outside the park boundaries. In this case, the FWS was attributed slightly more responsibility (31\%) than the rancher (29\%).

Visitors allotted responsibility to the GRTE higher for encounters within the park, at about one fourth of the total responsibility for cattle encounters (Scenario 2, 25\%; Scenario 6, $26 \%$ ). The hiker encounters are not as homogeneous in visitors' allotment of responsibility as might be anticipated. Scenario 5 (Figure 6), which depicts wolves denning near a trail, shows the highest PV allotted responsibility to GRTE (29\%) while Scenario 1 (Figure 2), with wolves feeding on a kill, near a trail, only had $15 \%$ of overall visitor responsibility allotted to GRTE. Our interpretation of this seeming anomaly is that denning is a much more permanent presence of wolves, requiring park attention, than is feeding on a kill. Perhaps, since Scenario 1 attribution of responsibility was so high (65\% for visitors - the highest level attributed to any agent by either respondent group; Figure 2), respondents were expressing the notion that any hiker with a modicum of good sense should keep away from a pack of wolves feeding on a wildlife kill.

Visitors basically attribute very little responsibility to the WYG\&F for encounters within the park: responsibility allocation to this agency ranging from 6-8\% for hiker encounters to $11 \%$ for cattle allotment encounters. Outside of the park, the predation encounters with cattle (Scenario 3) and with a pet (Scenario 4) showed one fifth of responsibility attributed by PV to the WYG\&F.

Whereas visitors focused on individuals - hikers, ranchers, etc. - being most responsible, the Local Residents [LR] tended to place responsibility most heavily upon the FWS (33\% overall average). For all scenarios except hiker encounters, FWS was allocated the highest levels of responsibility by the LR. Within this set of depredation or near-predation scenarios, in those 10 
occurring outside the park the LR allotted the highest responsibility to the FWS: $44 \%$ for cattle predation (Scenario 3) and 38\% for pet predation (Scenario 4); and the lowest levels of responsibility for the GRTE (14\% and 12\%, respectively). For cattle encounters within the park, LR allocated about one third of total responsibility to the FWS (Scenario 2, 35\%; Scenario 6, $33 \%)$.

With the single exception of Scenario 1, where such great proportions of responsibility were allotted to the hiker, local residents attributed less responsibility to the GRTE than did the visitors: between one-fourth and one-fifth within the park boundaries and between one-seventh and one-eighth for out-of-park Scenarios 3 and 4.

Again, compared to the FWS or the individual involved, local residents held the WYG\&F less responsible: $16 \%$ responsibility overall. The GRTE was just slightly higher at $18 \%$ overall average responsibility. WYG\&F was attributed more responsibility for out-of-park scenarios than for in-park encounters - indeed, residents and visitors agreed in attributing one fifth of responsibility to WYG\&F for out-of-park depredation. In other words, both wildlife agencies (FWS and WYG\&F) were allotted their highest responsibilities by both samples (PV \& LR) for off-park kill situations and their lowest for in-park hiker situations (see also Figure 8).

Scenarios 1 through 3 depicted wolves still in endangered species, experimental population status, while Scenarios 4 through 6 depicted the wolves as delisted (removed from endangered species status). There is no significant difference in assigned responsibility for the USFWS (26\% overall average responsibility for Scenarios 1-3; 28\% for Scenarios 4-6) nor for the WYG\&F (14\%-15\%, respectively) between the endangered and delisted sets of scenarios (see Figure 8). The public does not understand the change in responsibility associated with Endangered Species Act status.

Another unanticipated result is the nearly identical assigned responsibility for the two inpark grazing allotment scenarios: Scenario 2 (Figure 3) depicts harassment but no kills of cattle while Scenario 6 (Figure 7) shows depredation. It is in the area of acceptable management actions where respondents differentiated between harassment and kills.

A repeated measures ANOVA was conducted which revealed a significant interaction effect, among scenarios, of percentages of assigned responsibility and the samples of LR and PV $(F=2.92, p<.001$, Figure 8$)$. Park visitors' average percentages of assigned responsibility for the individual involved in a potential conflict with wolves were higher than local residents' across all scenarios (Figure 8-A). Conversely, local residents' average percentages of assigned responsibility for the USFWS were significantly higher than park visitors' for this agency across all scenarios (Figure 8-D). Park visitors were slightly more likely to assign responsibility to the GRTE than local residents for most scenarios (Figure 8-B), while local residents were slightly more likely than park visitors to assign responsibility to WYG\&F (Figure 8-C). The near-parallel line patterns in Figure 8 indicate consistency between residents and visitors in how responsibility for any one agent varied from one wolf encounter situation to another.

\section{Acceptance of Management Actions}

Management action alternatives were tailored to match different types of human-wolf encounters, and therefore are not universally comparable across scenarios. For example, lethal methods of wolf control were not offered for trail encounters in the park, but trail and trailsection closures were. For in-park livestock encounters, moving or removing the cattle from the allotment were offered alternatives; these options were not offered for out-of-park encounters. Ttests were used to differentiate between average acceptability ratings for each of the possible management actions given (Tables 4 through 9). For all scenarios, park visitors rated the choice "monitor the situation" more favorably than local residents: PV mean responses were greater than 4.4 for every scenario; LR mean responses ranged from 3.3, for off-park depredation 
scenarios, to $4.5 ; t=7.46, p \leq .001$. (It should be borne in mind that the evaluations scale was seven points, with 4.0 being the neutral central point.) For those situations where wolves had not caused any loss of cattle or pets (Scenarios 1, 2, and 5; Tables 4, 5, and 8), local residents rated management options aimed at prevention of human-wolf interaction (i.e., trail closure or cattle removal from federal grazing allotments) as significantly less acceptable than did park visitors (LR mean range 2.6-3.6; PV mean range 3.1-4.5; $t=5.31, p \leq .001$ ). For those scenarios where wolves did cause loss of pets or cattle (Scenarios 3, 4, and 6; Tables 6, 7, and 9), local residents rated non-lethal management options (i.e., capture and relocate, or frighten the wolves away)

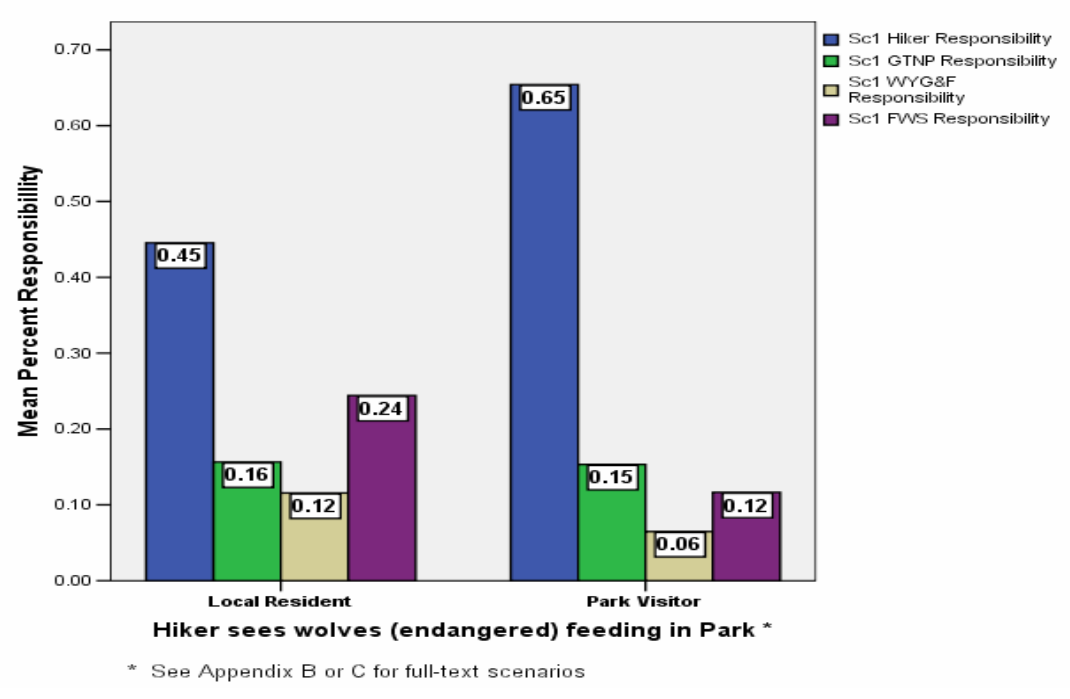

Figure 2. Scenario 1 attributed responsibility.

Wolves, endangered, feeding near trail in GRTE.

Table 4. Mean acceptability ratings for five management actions following a hypothetical hikingtrail human-wolf interaction (scenario 1).

\begin{tabular}{lccccc}
\hline & \multicolumn{2}{c}{ Mean acceptability rating $^{\mathbf{a}}$} & & \\
\cline { 2 - 3 } Management action & Resident & Visitor & t-statistic & $\boldsymbol{p}_{\text {-value }} \mathbf{v}^{\mathbf{b}}$ \\
\hline Monitor the situation & 4.5 & 5.3 & 9.25 & $<.001$ \\
Frighten the wolves away & 3.4 & 3.1 & 2.56 & .011 \\
Capture and relocate the wolves involved & 3.4 & 2.7 & 7.43 & $<.001$ \\
Close only the section of the trail that the wolves are near & 3.1 & 4.0 & 9.70 & $<.001$ \\
Close the entire trail until the wolves have left the area & 2.6 & 3.1 & 5.31 & $<.001$ \\
\hline
\end{tabular}

${ }^{\mathrm{a}}$ Respondents were asked to rate acceptability of management actions, on a Likert-type scale, from 1 = 'highly unacceptable' through $7=$ 'highly acceptable'. The 'no opinion' category was removed and the acceptability ratings were recoded to $1=$ 'highly unacceptable' through $6=$ 'highly acceptable'.

${ }^{\mathrm{b}} \mathrm{A}$ Bonferroni multiple-test comparison correction was use to adjust significance levels. All values shown are statistically significant at $p<.01$. 
significantly less acceptable than park visitors (LR mean response 3.0-4.1; PV mean response $4.0-4.5 ; \mathrm{t}=2.67, p=.008)$. In these latter three scenarios, local residents rated "destroy the wolves involved" as more acceptable to acceptable (mean response 3.8-4.1), whereas park visitors rated this management option as unacceptable to somewhat unacceptable (mean response 2.4-2.7; $t=12.32, p \leq .001$ ). The latter, lethal options, were the only management alternatives where the range of overall acceptability between PV and LR did not overlap.

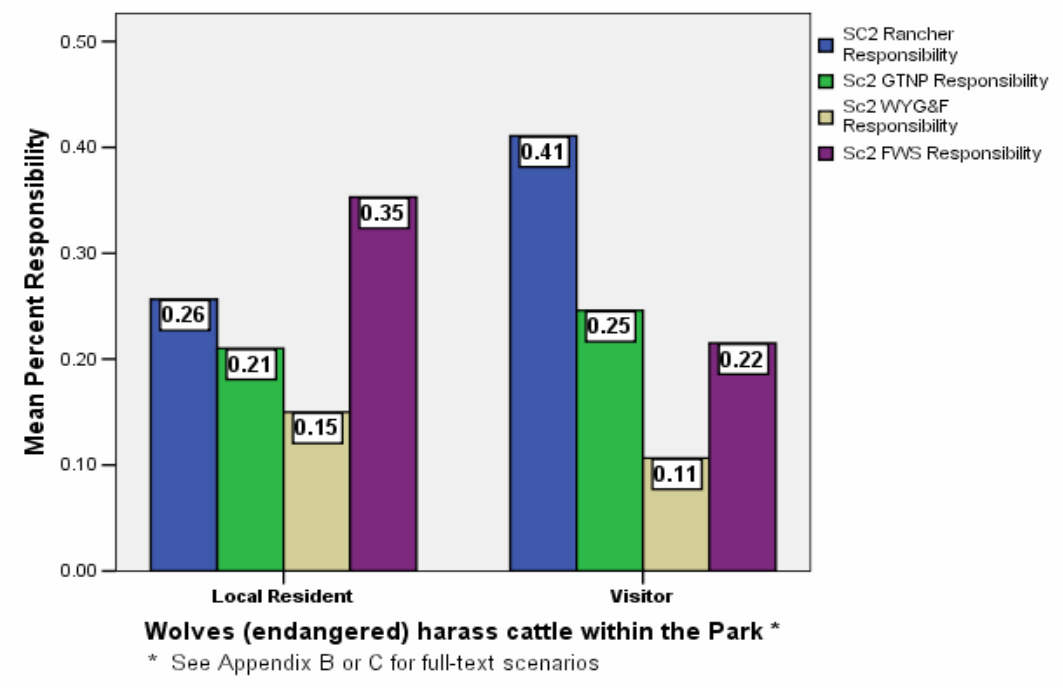

Figure 3. Scenario 2 attributed responsibility.

Wolves, endangered, chasing cattle in GRTE.

Table 5. Mean acceptability ratings for six management actions following a hypothetical cattlewolf interaction (scenario 2).

\begin{tabular}{lccccc}
\hline & \multicolumn{2}{c}{ Mean acceptability rating $^{\mathrm{a}}$} & & \\
\cline { 2 - 3 } Management action & Resident & Visitor & t-statistic & $\boldsymbol{p}_{\text {-value }}$ \\
\hline Monitor the situation & 4.1 & 5.0 & 9.67 & $<.001$ \\
Frighten the wolves away & 3.8 & 4.1 & 2.93 & .003 \\
Capture and relocate the wolves involved & 4.0 & 3.4 & 5.55 & $<.001$ \\
Move the cattle to another area of the grazing allotment & 3.4 & 4.5 & 10.38 & $<.001$ \\
Remove the cattle in question from the park & 2.7 & 3.7 & 8.63 & $<.001$ \\
Destroy the wolves involved & 3.0 & 1.7 & 13.96 & $<.001$ \\
\hline
\end{tabular}

${ }^{a}$ Respondents were asked to rate acceptability of management actions, on a Likert scale, from $1=$ 'highly unacceptable' through $7=$ 'highly acceptable'. The 'no opinion' category was removed and the acceptability ratings were recoded to $1=$ 'highly unacceptable' through $6=$ 'highly acceptable'.

${ }^{\mathrm{b}} \mathrm{A}$ Bonferroni multiple-test comparison correction was use to adjust significance levels. All values shown are statistically significant at $p<.008$. 


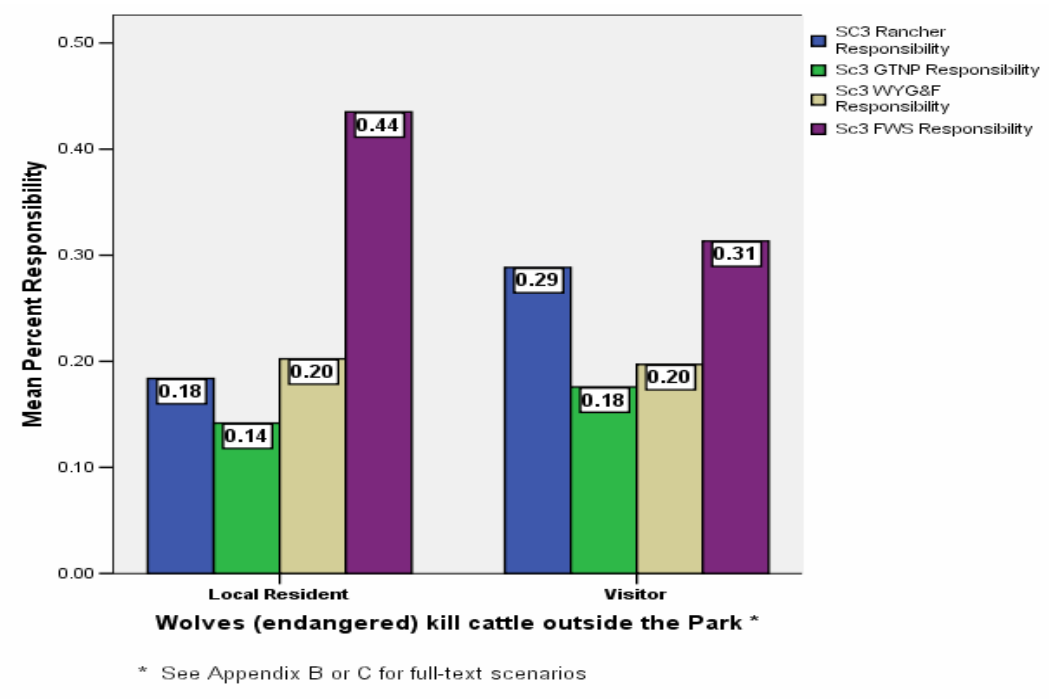

Figure 4. Scenario 3 attributed responsibility.

Wolves, endangered, killed cattle on private land.

Table 6. Mean acceptability ratings for four management actions following a hypothetical cattle wolf interaction (scenario 3).

\begin{tabular}{lccccc}
\hline & \multicolumn{2}{c}{ Mean acceptability rating } & & \\
\cline { 2 - 3 } Management action & Resident & Visitor & & t-statistic & $\boldsymbol{p}^{\text {-value }^{\mathbf{b}}}$ \\
\hline Monitor the situation & 3.3 & 4.4 & 10.55 & $<.001$ \\
Frighten the wolves away & 3.5 & 4.5 & 10.06 & $<.001$ \\
Capture and relocate the wolves involved & 4.1 & 4.5 & 4.22 & $<.001$ \\
Destroy the wolves involved & 3.8 & 2.4 & 13.19 & $<.001$ \\
\hline
\end{tabular}

${ }^{a}$ Respondents were asked to rate acceptability of management actions, on a Likert-type scale, from $1=$ 'highly unacceptable' through $7=$ 'highly acceptable'. The 'no opinion' category was removed and the acceptability ratings were recoded to $1=$ 'highly unacceptable' through $6=$ 'highly acceptable'.

${ }^{\mathrm{b}}$ A Bonferroni multiple-test comparison correction was use to adjust significance levels. All values shown are statistically significant at $p<.01$. 


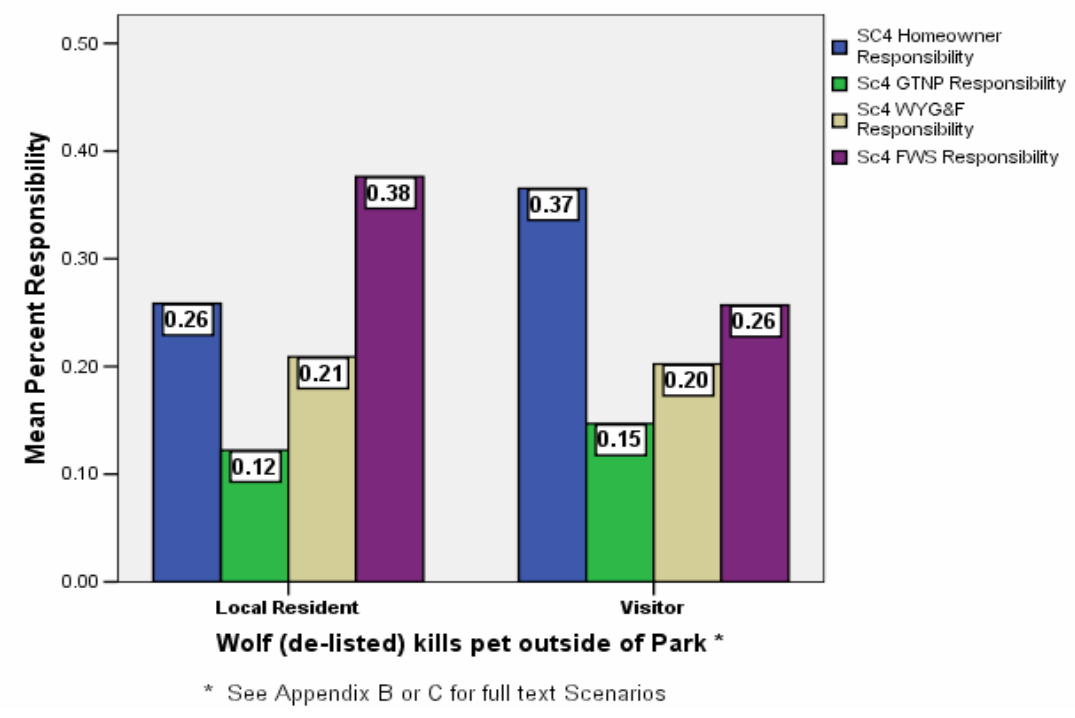

Figure 5. Scenario 4 attributed responsibility.

Wolves, delisted, killed pet on private land.

Table 7. Mean acceptability ratings for four management actions following a hypothetical petwolf interaction (scenario 4).

\begin{tabular}{|c|c|c|c|c|}
\hline \multirow[b]{2}{*}{ Management action } & \multicolumn{2}{|c|}{ Mean acceptability rating ${ }^{\mathrm{a}}$} & \multirow[b]{2}{*}{ t-statistic } & \multirow[b]{2}{*}{$p$-value } \\
\hline & Resident & Visitor & & \\
\hline Monitor the situation & 3.3 & 4.4 & 11.14 & $<.001$ \\
\hline Frighten the wolves away & 3.4 & 4.5 & 11.90 & $<.001$ \\
\hline Capture and relocate the wolves involved & 4.0 & 4.5 & 5.81 & $<.001$ \\
\hline Destroy the wolves involved & 4.1 & 2.7 & 12.32 & $<.001$ \\
\hline
\end{tabular}

${ }^{\mathrm{a}}$ Respondents were asked to rate acceptability of management actions, on a Likert-type scale, from 1 = 'highly unacceptable' through 7 = 'highly acceptable'. The 'no opinion' category was removed and the acceptability ratings were recoded to $1=$ 'highly unacceptable' through $6=$ 'highly acceptable'.

${ }^{\mathrm{b}}$ A Bonferroni multiple-test comparison correction was use to adjust significance levels. All values shown are statistically significant at $p<.01$. 


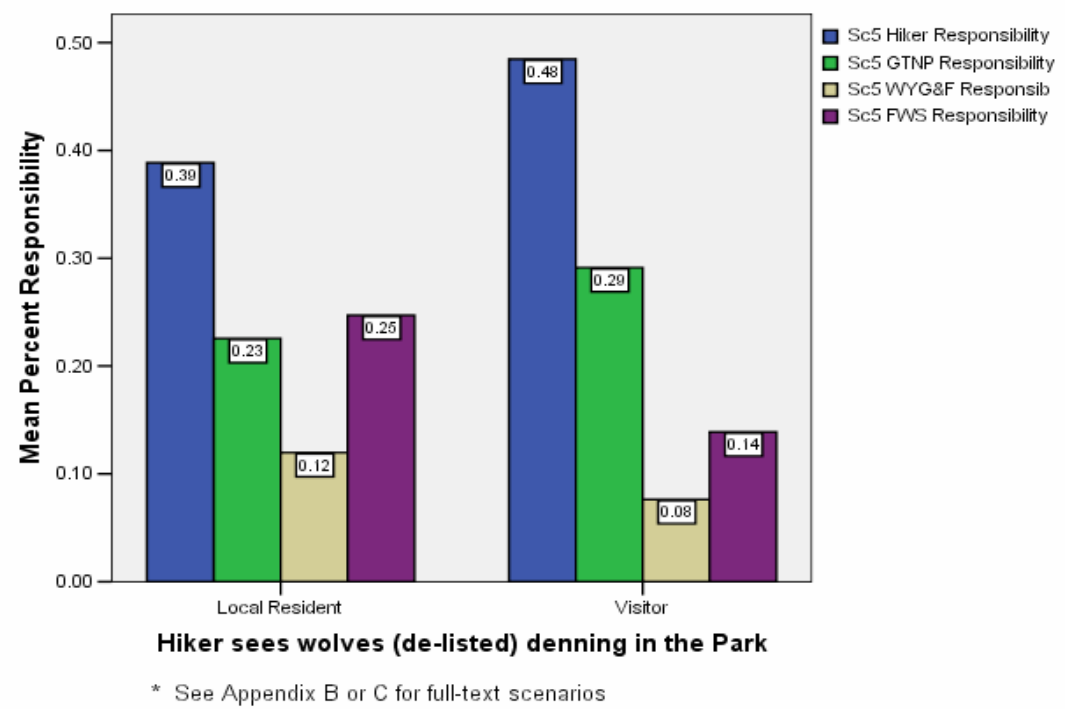

Figure 6. Scenario 5 attributed responsibility.

Wolves, delisted, denning near trail in GRTE.

Table 8. Mean acceptability ratings for five management actions following a hypothetical hiking trail-wolf interaction (scenario 5).

\begin{tabular}{lccccc}
\hline & \multicolumn{2}{c}{ Mean acceptability rating $^{\mathbf{a}}$} & & \\
\cline { 2 - 3 } Management action & Resident & Visitor & t-statistic & $\boldsymbol{p}_{\text {-value }} \mathbf{v}^{\mathbf{b}}$ \\
\hline Monitor the situation & 4.3 & 5.0 & 7.46 & $<.001$ \\
Frighten the wolves away & 2.6 & 2.6 & 0.36 & .723 \\
Capture and relocate the wolves involved & 3.1 & 2.7 & 3.73 & $<.001$ \\
Close only the section of the trail that the wolves are near & 3.6 & 4.5 & 9.44 & $<.001$ \\
Close the entire trail until the wolves have left the area & 2.8 & 3.4 & 6.18 & $<.001$ \\
\hline
\end{tabular}

${ }^{\mathrm{a}}$ Respondents were asked to rate acceptability of management actions, on a Likert-type scale, from $1=$ 'highly unacceptable' through $7=$ 'highly acceptable'. The 'no opinion' category was removed and the acceptability ratings were recoded to $1=$ 'highly unacceptable' through $6=$ 'highly acceptable'.

${ }^{\mathrm{b}}$ A Bonferroni multiple-test comparison correction was use to adjust significance levels. All values, except 'frighten the wolves away', are statistically significant at $p<.01$. 


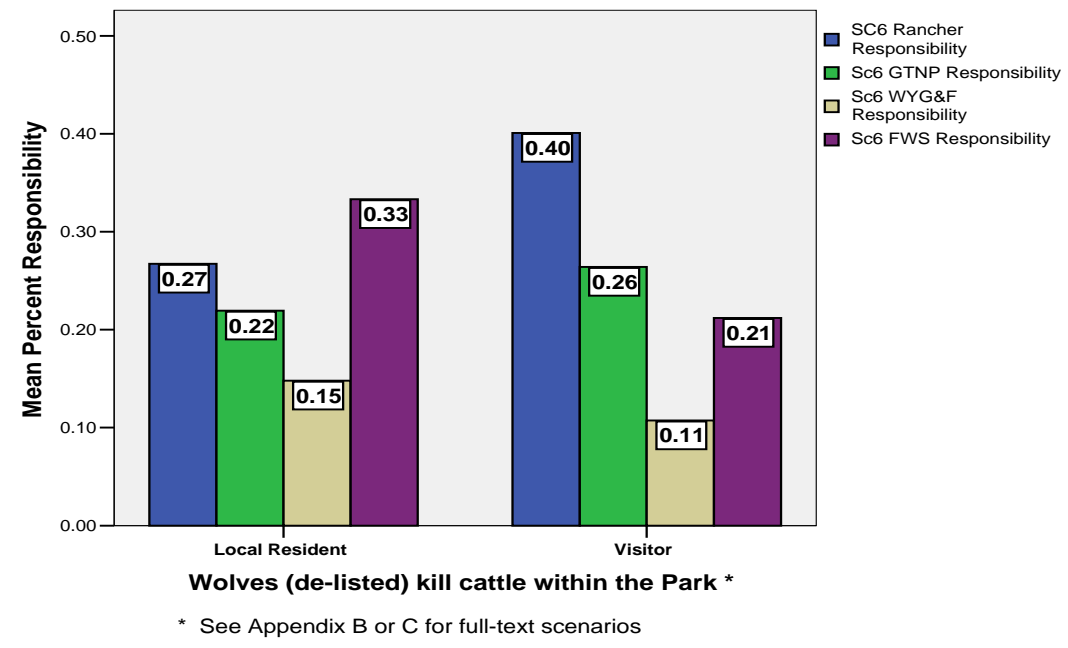

Figure 7. Scenario 6 attributed responsibility.

Wolves, delisted, killed cattle in GRTE.

Table 9. Mean acceptability ratings for six management actions following a hypothetical cattle wolf interaction (scenario 6).

\begin{tabular}{lccccc}
\hline & \multicolumn{3}{c}{ Mean acceptability rating $^{\mathrm{a}}$} & & \\
\cline { 2 - 3 } Management action & Resident & Visitor & t-statistic & $\boldsymbol{p}_{\text {-value }}$ \\
\hline Monitor the situation & 3.5 & 4.5 & 9.93 & $<.001$ \\
Frighten the wolves away & 3.4 & 4.2 & 7.86 & $<.001$ \\
Capture and relocate the wolves involved & 3.8 & 4.0 & 2.67 & .008 \\
Move the remaining cattle to another area of the grazing & 3.5 & 4.5 & 10.82 & $<.001$ \\
allotment & 3.0 & 3.9 & 8.83 & $<.001$ \\
Remove the remaining cattle in question from the park & 3.8 & 2.4 & 12.65 & $<.001$ \\
Destroy the wolves involved & &
\end{tabular}

${ }^{\mathrm{a}}$ Respondents were asked to rate acceptability of management actions, on a Likert-type scale, from 1 = 'highly unacceptable' through $7=$ 'highly acceptable'. The 'no opinion' category was removed and the acceptability ratings were recoded to $1=$ 'highly unacceptable' through $6=$ 'highly acceptable'.

${ }^{\mathrm{b}}$ A Bonferroni multiple-test comparison correction was use to adjust significance levels. All values shown are statistically significant at $p<.008$. 

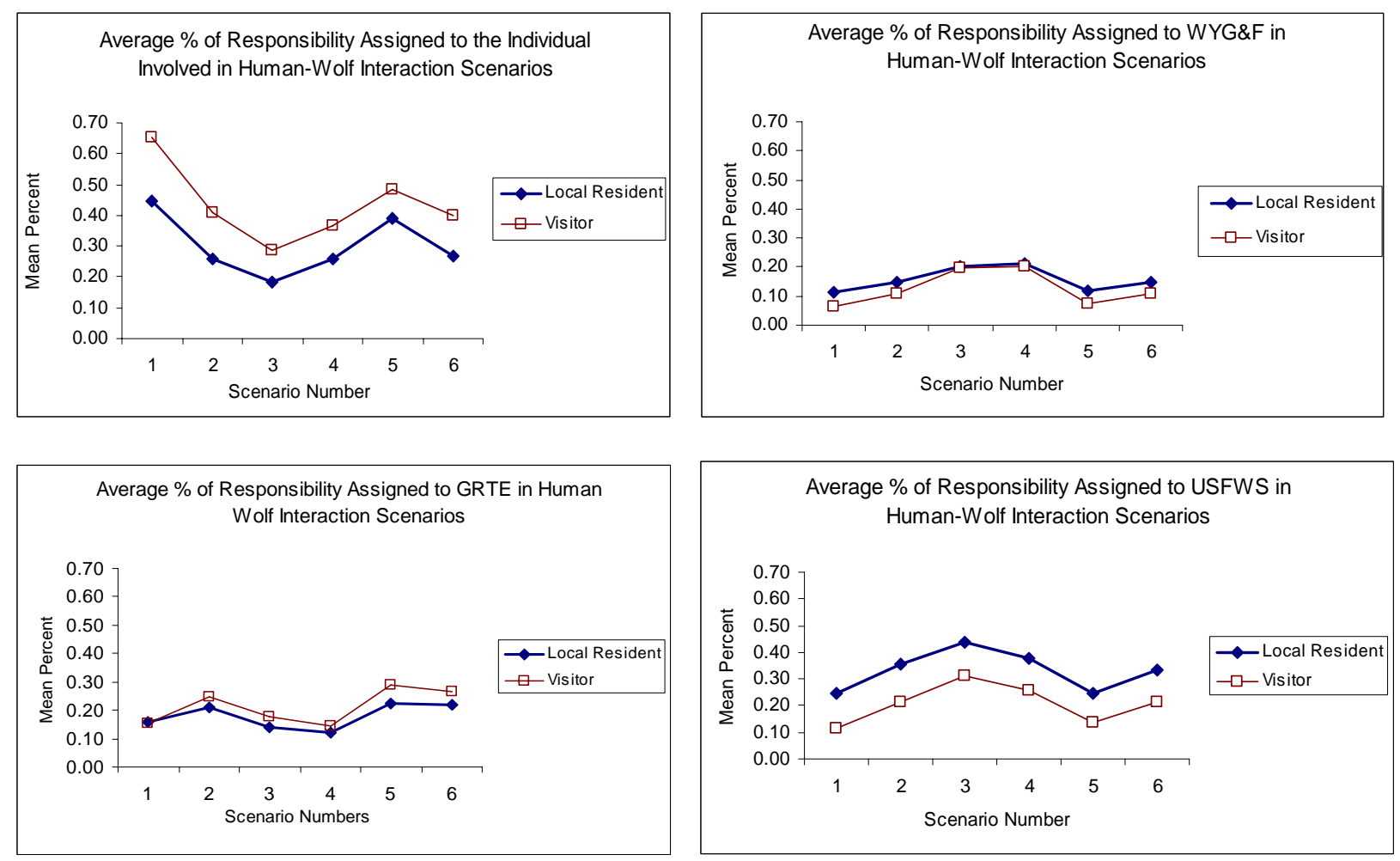

Figure 8. Average percent of responsibility assigned by residents and visitors to each of four possible agents involved in hypothetical human-wolf interactions across six hypothetical scenarios. ${ }^{\text {a.b }}$

${ }^{a}$ Scenarios 1 through 3 listed the wolves involved in hypothetical conflict as an endangered species, experimental population. Scenarios 4 through 6 listed the wolf numbers as having increased and no longer listed the wolves as an endangered species.

${ }^{\mathrm{b}}$ A repeated measures ANOVA revealed a significant interaction effect of situation * agent assigned responsibility * location of survey (resident vs. visitor), $F=2.92, p<.001$

Because the lethal management option, "kill the wolves (wolf) involved," which was offered for the four scenarios showing predation, showed the strongest differentiation between LR and PV, among the management alternatives offered, we created a normative variable to help explain some of this difference. To create this variable, we identified three different response patterns: those who always accepted the lethal option when it was offered, those who never found the lethal option acceptable, and those who sometimes found this action acceptable and sometimes did not (Table 10).

The first result of importance to note here is that nearly half of the total aggregate sample never selected the lethal management option, $64 \%$ of PV never chose kill the wolves involved. The second important result is that a plurality $(40 \%)$ of local residents always selected the lethal option when it was offered, whereas only $10 \%$ of visitors always selected kill the wolves, i.e., LR are four times more likely to always select "kill the wolves" than are PV. 
Table 10. Cross-tabulation of wolf kill-norm with resident and visitor samples. ${ }^{\text {a.b }}$

\begin{tabular}{lcccc}
\hline & $\begin{array}{c}\text { Never kill the } \\
\text { wolves }\end{array}$ & $\begin{array}{c}\text { Sometimes kill the } \\
\text { wolves }\end{array}$ & $\begin{array}{c}\text { Always kill the } \\
\text { wolves }\end{array}$ & Total \\
\hline Local resident & 176 & 154 & 223 & 553 \\
& $31.8 \%$ & $27.8 \%$ & $40.3 \%$ & $49.6 \%$ \\
Park visitor & 361 & 144 & 57 & 562 \\
& $64.2 \%$ & $25.6 \%$ & $10.1 \%$ & $50.4 \%$ \\
\hline Totals & 537 & 298 & 289 & 1115 \\
& $48.2 \%$ & $26.7 \%$ & $25.9 \%$ & $100 \%$ \\
\hline
\end{tabular}

${ }^{\mathrm{a}}$ Percentages are the proportion of each respondent sample following that norm response pattern, i.e., row percentages.

${ }^{\mathrm{b}}$ Chi-Square test of association showed significant difference between LR and PV: $\chi^{2}=162.4, p<.001$.

\section{Judgments of Effectiveness of Wolf Management Actions}

Respondents were asked to rate the effectiveness of several potential management options for preventing or remedying conflicts between wolves and human activities or properties. The judgment scale was from $1=$ 'not at all effective' to 4 = 'extremely effective'. T-tests were used to differentiate between average perceived effectiveness ratings for each management option for local residents and park visitors (Table 11).

Closure of trails or trail sections to avoid human-wolf disturbances received the highest marks for effectiveness, averaging between 'somewhat effective' and 'effective' for both sample groups, although visitors (mean $=2.8$ ) rated these preventive actions significantly more effective than did residents (means $=2.3$ and $2.4 ; p \leq .001$ ). Next, "capture and relocation of an entire pack involved" was ranked midway between "somewhat effective" and "effective" by both groups. Residents rated the effectiveness of "destroy the entire pack involved" significantly higher (mean $=2.6$ ) than did visitors to GRTE (mean $=2.0 ; t=6.25, p \leq .001$ ); and residents also judged destroying the breeding pair or an individual wolf significantly higher in effectiveness than visitors. But none of these were rated very strongly effectively; the mid-point on the 4-point scale being 2.5 . 
Table 11. Mean ratings of resident and visitor perceptions of management action effectiveness to alleviate human-wolf conflicts.

\begin{tabular}{|c|c|c|c|c|}
\hline \multirow[b]{2}{*}{ Management actions } & \multicolumn{2}{|c|}{$\begin{array}{c}\text { Mean perceived } \\
\text { effectiveness } \\
\text { rating }^{\mathrm{a}}\end{array}$} & \multirow[b]{2}{*}{ t-statistic } & \multirow[b]{2}{*}{$p$-value ${ }^{b}$} \\
\hline & Resident & Visitor & & \\
\hline \multicolumn{5}{|l|}{ To prevent wolves from entering an area on private property... } \\
\hline Frightening devices, loud sirens, or flashing lights & 1.5 & 1.7 & 2.68 & .008 \\
\hline Electric fences & 1.7 & 2.1 & 5.67 & $<.001$ \\
\hline Guard dogs & 1.5 & 1.6 & 1.13 & .258 \\
\hline Shooting at wolves with non-lethal rubber bullets & 1.9 & 1.8 & .95 & .340 \\
\hline \multicolumn{5}{|l|}{$\begin{array}{l}\text { To avoid human-wolf disturbances within Grand Teton } \\
\text { National Park... }\end{array}$} \\
\hline $\begin{array}{l}\text { Closure of sections of hiking trails that are close to wolf } \\
\text { denning areas }\end{array}$ & 2.4 & 2.8 & 6.90 & $<.001$ \\
\hline $\begin{array}{l}\text { Closure of entire hiking trails that pass near wolf denning } \\
\text { sites }\end{array}$ & 2.3 & 2.8 & 7.36 & $<.001$ \\
\hline \multicolumn{5}{|l|}{$\begin{array}{l}\text { To reduce future threat to human property following instances } \\
\text { of conflict between wolves and human activities or property... }\end{array}$} \\
\hline Capture and relocation of an entire pack involved & 2.4 & 2.5 & 1.61 & .108 \\
\hline Capture and relocation of an individual wolf involved & 1.9 & 1.9 & .40 & 690 \\
\hline Destroy an individual wolf that was in a pack involved & 2.1 & 1.7 & 6.23 & $<.001$ \\
\hline Destroy the breeding pair of wolves in a pack involved & 1.9 & 1.5 & 5.53 & $<.001$ \\
\hline Destroy the entire pack involved & 2.6 & 2.0 & 6.25 & $<.001$ \\
\hline
\end{tabular}

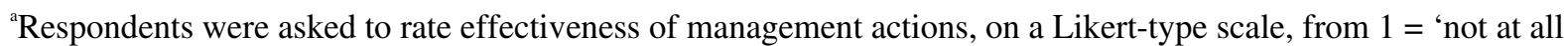
effective' through $4=$ 'extremely effective'.

${ }^{\mathrm{b}}$ A Bonferroni multiple-test comparison correction was use to adjust significance levels. $P$-values shown are only statistically significant at $p<.004$.

All other management options, for exclosure of wolves, or capturing and relocating a single wolf, were rated between 'not at all' and 'somewhat effective' by both groups. Most of these showed little difference between local residents and park visitors except on their perceptions of the effectiveness of electrical fences to prevent wolves from entering private property, although different definitions between urban and rural populations of "electric fence" may have influenced this result.

\section{Emotions Felt about Wolves}

Respondents evaluated a series of emotion statements by indicating the degree to which they agreed or disagreed with each. These emotion items were designed to measure four distinct classes of emotion that might be associated with the existence of wolves in the Jackson Hole area (see Table 13): anger about the presence of wolves (A, B, C, G, K); fear of wolves (D, E, N, O, $P, \mathrm{Q})$; sympathy toward wolves $(\mathrm{F}, \mathrm{I}, \mathrm{M})$; and sympathy toward ranchers $(\mathrm{H}, \mathrm{J}, \mathrm{L})$.

Park visitors and local residents are compared in these results, first in the aggregate emotion indices (Table 12) then in specific emotion item responses (Table 13). Reliability tests of these aggregate emotion indices are reported in Appendix D. 
Table 12. Local resident and park visitor overall responses to the aggregated emotion indices. ${ }^{a}$

\begin{tabular}{lcccc}
\hline & $\begin{array}{c}\text { Anger about } \\
\text { wolf presence }\end{array}$ & $\begin{array}{c}\text { Sympathy for } \\
\text { wolves }\end{array}$ & $\begin{array}{c}\text { Sympathy for } \\
\text { ranchers }\end{array}$ & Fear of wolves \\
\hline Local residents $^{\text {rark visitors }}$ & 3.5 & 2.4 & 4.0 & 3.6 \\
Measure of association $^{\mathrm{b}}$ & 2.7 & 3.3 & 3.4 & 3.3 \\
\hline
\end{tabular}

${ }^{\mathrm{a}}$ Emotion items used a Likert scale from $1=$ strongly disagree to $5=$ strongly agree.

${ }^{b}$ Eta squared measures of association: a value of 0.1 would indicate a minimal level of association.

Differences in emotional response were greatest in the areas of anger about wolves and sympathy toward wolves. Local residents tended to express anger about wolf presence while park visitors were more prone to feeling sympathy toward wolves. Both sample groups felt that fear of wolves was understandable, and both groups showed some sympathy with ranchers. None of these aggregate emotion classes showed strong association with the population samples.

The following text and Table 13 give item-by-item descriptions of the components of the emotion classes listed above. For this comparison, the 5-point scale results were aggregated, into 'agree,' 'neutral,' and 'disagree' for ease in displaying the proportions of the two samples who agreed and who disagreed with each emotion item.

Chi-square tests of association showed significant differences between local residents and park visitors for most of the individual emotion items (Table 13). For example, although $43 \%$ of park visitors disagreed, fully $35 \%$ agreed with statement F, "I have sympathy for wolves that rely on livestock for food"; whereas among local residents only 19\% agreed and 69\% disagreed with this sentiment $\left(\chi^{2}=79.94, p<.001\right)$. Local residents agreed $(60 \%)$ with I, "I don't have any sympathy for wolves that are destroyed for killing livestock," but $68 \%$ of park visitors disagreed with this statement $\left(\chi^{2}=184.85, p<.001\right)$. Finally, 59\% of park visitors, compared to $34 \%$ of local residents, agreed with $\mathrm{M}$, "I feel sorry for wolves when they are destroyed for any reason" $\left(\chi^{2}=89.5, p<.001\right)$.

Regarding emotions of anger felt towards wolves and/or wolf predation being present, $62 \%$ of local residents agreed with A, "I get angry when I learn that a wolf has destroyed someone's livestock," whereas only $29 \%$ of park visitors agreed with this statement $\left(\chi^{2}=143.29\right.$, $p<.001)$. Conversely, park visitors (67\%), more than local residents (37\%), agreed with, G, "It angers me to learn that wolves may be destroyed if they harass livestock but don't actually kill them" $\left(\chi^{2}=131.79, p<.001\right)$.

By far, the majority agreed (87\% LR and $85 \%$ PV) that they could understand people fearing wolves (Q); and about $80 \%$ disagreed with the converse, $\mathrm{D}$, that no one should be afraid of wolves. Approximately 60-70\% of the two groups disagreed with N, "I would never be fearful of a wolf, if I saw one on my property," and also with E, "I would never worry about my safety in an area that had wolves," both of which resulted in modestly significant differences $\chi^{2}$ $=6.00, p=0.05$ and $\chi^{2}=7.06, p=.029$, respectively) between residents and visitors.

It is important for GRTE to note that the majority of both park visitors and local residents do not feel anger $(\mathrm{K}$, disagree: $\mathrm{PV}=86 \%, \mathrm{LR}=57 \%)$ nor fear $(\mathrm{P}$, disagree: $\mathrm{PV}=85 \%, \mathrm{LR}=$ $59 \%$ ) that wolves are living in the park and may be encountered. Virtually none of the visitors (6\% and $7 \%$, respectively) agreed with those statements. 
They agreed that it both saddens $(\mathrm{H}, \mathrm{LR}=79 \%$; $\mathrm{PV}=61 \%)$ and upsets them $(\mathrm{J}, \mathrm{LR}=$ $67 \%$; PV $=39 \%$ - a plurality) "to know that ranchers lose livestock to wolves," although to significantly different degrees. In addition, both groups disagreed with C, "I don't understand ... anger when wolves destroy livestock" (77\% LR, 68\% PV). A strong majority of local residents $(82 \%)$ and park visitors $(75 \%)$ disagreed with L, "I have no sympathy for ranchers who lose livestock to wolf attacks."

Table 13. Local resident and park visitor emotions towards wolves and their management in and around Grand Teton National Park.

\begin{tabular}{|c|c|c|c|c|c|c|c|c|c|}
\hline \multirow{2}{*}{\multicolumn{2}{|c|}{ Emotion items ${ }^{\mathrm{a}}$}} & \multicolumn{3}{|c|}{ Local resident } & \multicolumn{3}{|c|}{ Park visitor } & \multirow[b]{2}{*}{$x$} & \multirow[b]{2}{*}{$\begin{array}{l}\frac{0}{\Xi} \\
\frac{0}{10} \\
\frac{1}{2}\end{array}$} \\
\hline & & 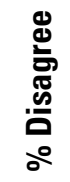 & $\frac{\Xi}{\frac{d}{0}}$ & 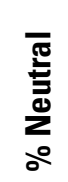 & 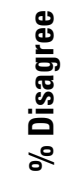 & $\begin{array}{l}\frac{8}{d} \\
\frac{0}{2} \\
0\end{array}$ & 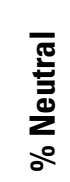 & & \\
\hline A. & $\begin{array}{l}\text { I get angry when I learn that a wolf has } \\
\text { destroyed someone's livestock }\end{array}$ & 19 & 62 & 19 & 46 & 29 & 25 & 143.29 & $<.001$ \\
\hline B. & $\begin{array}{l}\text { It does not anger me to know that pet dogs } \\
\text { may be attacked and killed by wild animals } \\
\text { such as wolves }\end{array}$ & 68 & 21 & 11 & 43 & 38 & 19 & 71.98 & $<.001$ \\
\hline C. & $\begin{array}{l}\text { I don't understand why some people become } \\
\text { angry when wolves destroy livestock }\end{array}$ & 77 & 14 & 9 & 68 & 19 & 13 & 11.72 & .003 \\
\hline D. & $\begin{array}{l}\text { I don't think anyone should be afraid of } \\
\text { wolves for any reason }\end{array}$ & 80 & 14 & 6 & 79 & 13 & 8 & 3.15 & .206 \\
\hline E. & $\begin{array}{l}\text { I would never worry about my safety in an } \\
\text { area that I knew had wolves }\end{array}$ & 69 & 22 & 9 & 62 & 28 & 10 & 7.06 & .029 \\
\hline F. & $\begin{array}{l}\text { I have sympathy for wolves that rely on } \\
\text { livestock for food }\end{array}$ & 69 & 19 & 12 & 43 & 35 & 22 & 79.94 & $<.001$ \\
\hline G. & $\begin{array}{l}\text { It angers me to learn that wolves may be } \\
\text { destroyed if they harass livestock but don't } \\
\text { actually kill them }\end{array}$ & 51 & 37 & 12 & 21 & 67 & 12 & 131.79 & $<.001$ \\
\hline H. & $\begin{array}{l}\text { It saddens me to know that ranchers may } \\
\text { suffer the loss of their livestock due to wolf } \\
\text { attacks }\end{array}$ & 10 & 79 & 11 & 20 & 61 & 19 & 45.57 & $<.001$ \\
\hline I. & $\begin{array}{l}\text { I don't have any sympathy for wolves that } \\
\text { are destroyed for killing livestock }\end{array}$ & 30 & 60 & 10 & 68 & 23 & 9 & 184.85 & $<.001$ \\
\hline $\mathrm{J}$ & $\begin{array}{l}\text { It upsets me to learn that livestock has been } \\
\text { destroyed by re-introduced wolves }\end{array}$ & 17 & 67 & 16 & 37 & 39 & 24 & 92.45 & $<.001$ \\
\hline K. & $\begin{array}{l}\text { I get angry with the NPS when I hear that } \\
\text { visitors in a national park may encounter } \\
\text { wolves }\end{array}$ & 57 & 24 & 19 & 86 & 6 & 8 & 122.18 & $<.001$ \\
\hline L. & $\begin{array}{l}\text { I have no sympathy for ranchers who lose } \\
\text { livestock to wolf attacks }\end{array}$ & 82 & 10 & 18 & 75 & 11 & 14 & 10.56 & .005 \\
\hline M. & $\begin{array}{l}\text { I feel sorry for wolves when they are } \\
\text { destroyed for any reason }\end{array}$ & 52 & 34 & 14 & 25 & 59 & 16 & 89.50 & $<.001$ \\
\hline $\mathrm{N}$. & $\begin{array}{l}\text { I would never be fearful of a wolf if I saw } \\
\text { one on my property }\end{array}$ & 69 & 21 & 10 & 61 & 26 & 13 & 6.00 & .05 \\
\hline O. & $\begin{array}{l}\text { It frightens me when I hear about wolves } \\
\text { killing a pet dog }\end{array}$ & 23 & 58 & 19 & 39 & 41 & 20 & 39.01 & $<.001$ \\
\hline $\mathrm{P}$. & $\begin{array}{l}\text { It scares me knowing that wolves are living } \\
\text { in GRTE }\end{array}$ & 59 & 25 & 16 & 85 & 7 & 8 & 101.57 & $<.001$ \\
\hline Q. & $\begin{array}{l}\text { I understand why some people are fearful of } \\
\text { wolves }\end{array}$ & 7 & 87 & 6 & 7 & 85 & 8 & 1.42 & .493 \\
\hline
\end{tabular}

${ }^{a}$ Emotion items were coded on a 5-point likert-type scale ranging from $1=$ 'strongly disagree' to $5=$ 'strongly agree'. These scales were collapsed to create three categories, disagree, agree and neutral to facilitate a chi-square test association analysis. 
Emotions perform several cognitive roles, the most important in this case being to mobilize public energy and resources. Angry individuals are more likely to write letters, attend public hearings, and protest - than are calm ones. The fact that so many respondents felt strong emotions about this issue is important. It is also important to sort out which of the issues are volatile and which enjoy more general agreement in dealing with the public around issues of wolf management.

\section{Experiences with Wolves: Personal and Potential}

\section{Personal Experience}

Respondents were asked if they had ever seen one or more wolves in the wild. Significantly more residents $(59 \%)$ than visitors $(34 \%)$ had seen one or more wolves in the wild $\left(\chi^{2}=158.35, p<.001\right.$; Table 14). A small number were unsure whether or not they had seen wolves, but 100 people did not answer this question. This might reflect a broader uncertainty; often people are unsure whether they have seen a wolf or some other large canid, depending on distance. The two respondent groups who had seen wolves differed significantly when asked how many times they had seen wolves in the wild; between two and four times, with residents having seen wolves significantly more often than visitors. Having seen wolves in GRTE, however, did not result in a significant difference between the two groups. Seeing wolves was less common for both groups in GRTE than in other wild areas. Respondents rated themselves as moderately knowledgeable about wolves, while residents reported slightly more knowledge than visitors.

Table 14. Local resident and park visitor self-reported personal experiences and knowledge levels about wolves.

\begin{tabular}{lcccc}
\hline Personal experiences with wolves & Resident & Visitor & Test statistic & p-value \\
\hline $\begin{array}{l}\text { Have you ever seen wolves or a single wolf } \\
\text { in the wild? }\end{array}$ & & & & \\
$\quad$ Yes & $59 \%$ & $34 \%$ & $\chi^{2}=158.35$ & $<.001$ \\
$\quad$ No & 33 & 66 & & \\
$\quad$ Not sure & 8 & 0 & $t=3.26$ & .001 \\
$\begin{array}{l}\text { How many times have you seen wolves in } \\
\text { the wild? }\end{array}$ & 3.5 times & 2.2 times & & \\
$\begin{array}{l}\text { How many times have you seen wolves in } \\
\text { GRTE? }\end{array}$ & 2.3 times & 1.4 times & $t=1.72$ & .087 \\
$\begin{array}{l}\text { Do you consider yourself to be } \\
\text { knowledgeable about wolves? }\end{array}$ & 3.1 & 2.8 & $t=4.73$ & .001 \\
\hline
\end{tabular}

'Only individuals who responded 'yes' to the question 'have you ever seen wolves or a single wolf in the wild' were included in these analyses.

${ }^{\text {b} M e a n ~ s e l f-r e p o r t e d ~ k n o w l e d g e ~ l e v e l ~ a b o u t ~ w o l v e s ~ m e a s u r e d ~ o n ~ a ~ s c a l e ~ o f ~} 1=$ 'not at all knowledgeable' to $5=$ 'very knowledgeable'.

\section{Potential Experiences with Wolves}

Aside from their personal experience with seeing wolves, we asked respondents to rate several hypothetical encounters with wolves as positive or negative experiences. We used a Likert-type scale from 1 = 'extremely positive' to 7 = 'extremely negative,' plus a 'don't know' option. For all hypothetical sightings and varying numbers of wolves (single wolf vs. an entire 
pack), park visitors consistently rated these experiences more positively than local residents (Table 15; Figures 9 and 10). All respondents felt that seeing either a lone wolf or a wolf pack within GRTE boundaries was a more positive experience than seeing such animals on their own property. The most negatively rated experience for both park visitors and local residents was seeing a pack of wolves traveling across their own property daily (PV mean $=5.1$; LR mean $=$ 5.8). Both groups also shared their most positively rated experience: Seeing a lone wolf in the distance on a hike in the park $(\mathrm{PV}$ mean $=2.0$; LR mean $=3.0)$.

Table 15. Average experience ratings for tolerable numbers of encounters with wolves; local residents and park visitors.

\begin{tabular}{|c|c|c|c|}
\hline \multirow[b]{2}{*}{ What type of experience would this be for you? } & \multicolumn{2}{|c|}{$\begin{array}{l}\text { Mean perceived } \\
\text { experience rating }\end{array}$} & \multirow[b]{2}{*}{ t-statistic ${ }^{b}$} \\
\hline & Resident & Visitor & \\
\hline \multicolumn{4}{|c|}{$\begin{array}{l}\text { You are camping at Grand Teton National Park and have seen a } \\
\text { wolf near the campground where you are staying... }\end{array}$} \\
\hline Once? & 3.5 & 2.5 & 9.32 \\
\hline Twice? & 4.1 & 3.1 & 8.65 \\
\hline Several times? & 4.8 & 3.9 & 7.16 \\
\hline \multicolumn{4}{|c|}{$\begin{array}{l}\text { You are hiking at Grand Teton National Park and see a lone wolf in } \\
\text { the distance... }\end{array}$} \\
\hline On one hike? & 3.0 & 2.0 & 11.02 \\
\hline On two separate hikes? & 3.4 & 2.2 & 10.67 \\
\hline On several hikes? & 3.9 & 2.8 & 8.26 \\
\hline \multicolumn{4}{|c|}{$\begin{array}{l}\text { You are hiking at Grand Teton National Park and see a pack of } \\
\text { wolves in the distance... }\end{array}$} \\
\hline On one hike? & 3.2 & 2.2 & 9.69 \\
\hline On two separate hikes? & 3.7 & 2.6 & 8.89 \\
\hline On several hikes? & 4.2 & 3.3 & 7.16 \\
\hline \multicolumn{4}{|c|}{ You see a lone wolf traveling across your own property... } \\
\hline Once a year? & 3.6 & 2.4 & 11.24 \\
\hline Once a month? & 4.3 & 2.9 & 11.54 \\
\hline Once a week? & 5.0 & 3.9 & 9.72 \\
\hline \multicolumn{4}{|c|}{ You see a pack of wolves traveling across your property... } \\
\hline Once a year? & 4.0 & 2.7 & 11.55 \\
\hline Once a month? & 4.7 & 3.5 & 10.38 \\
\hline Once a week? & 5.4 & 4.4 & 7.90 \\
\hline Daily? & 5.8 & 5.1 & 5.98 \\
\hline
\end{tabular}

${ }^{a}$ Respondents were asked to rate the experience for tolerable numbers of encounters with wolves, on a likert-type scale, from $1=$ 'extremely positive' through $7=$ 'extremely negative'.

${ }^{\mathrm{b}}$ All t-values shown are significant at $p<.001$, a Bonferroni multiple-test comparison correction was used to adjust significance levels.

The differences between park visitors' and local residents' experience ratings for tolerable numbers of wolf sightings on park and private lands are illustrated in Figures 9 and 10 (please note that the $x$ axis in both figures ranges from extremely positive at 1 to extremely negative at 7). Although group means for these experiences are statistically different for all items asked of respondents (Table 15), the two groups share a pattern of tolerance. As the numbers of wolves 
encountered increased, the quality of the experience decreased; and as the frequency of particular wolf sightings increased, the experience also became less positive. This similarity between park visitors and local residents is visually evident in the parallel lines in Figures 9 and 10. The difference between the two populations lies in the degree of positive or negative experience. For residents, 8 of the 17 items were rated, on average, above the neutral point of " 4 " (i.e., negative experience) while 6 were below (i.e., positive). For park visitors, a reverse pattern is true: 12 items were rated below " 4 " (positive), but only 3 were rated above (negative).

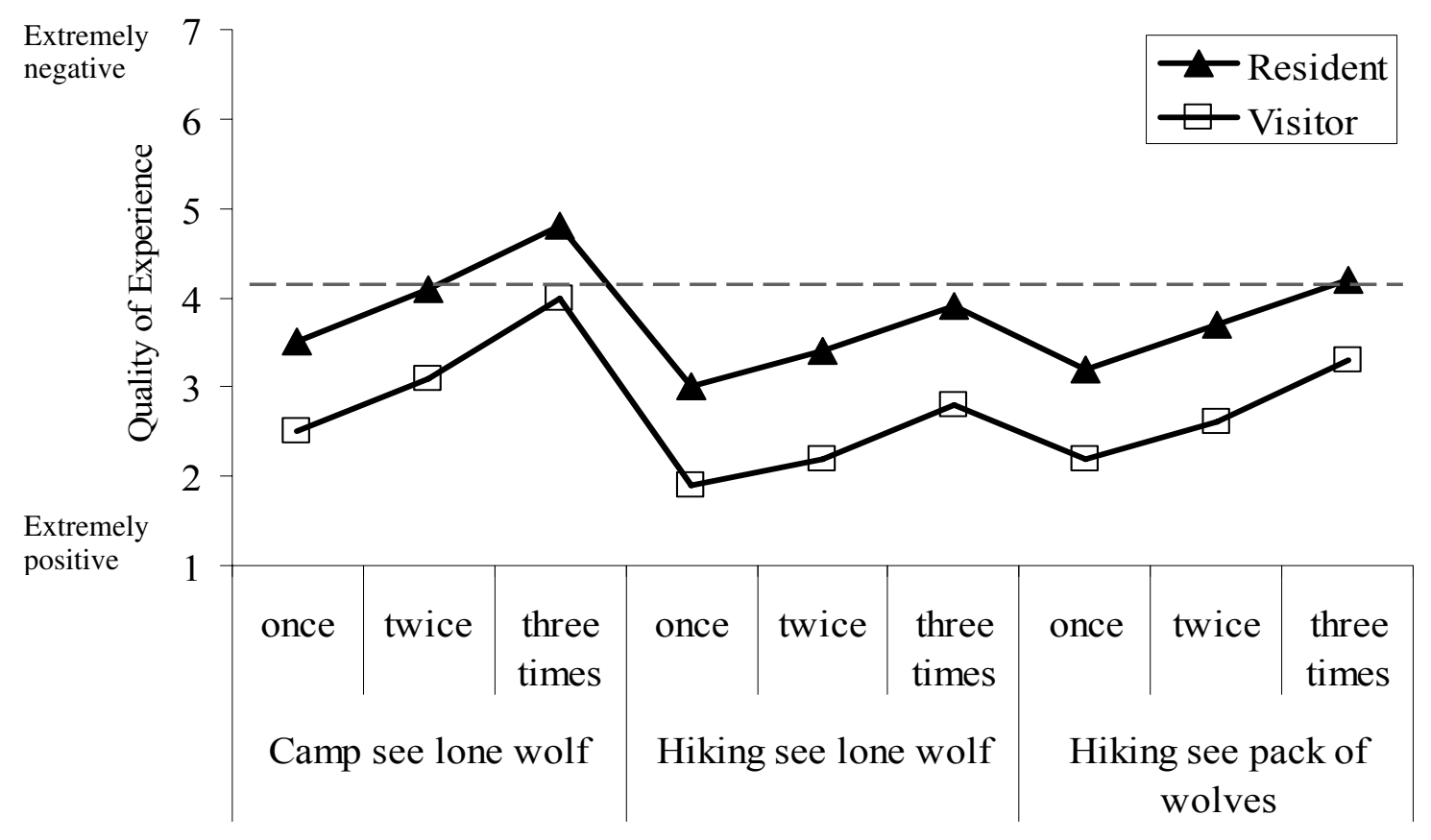

Figure 9. Average quality of experience level for various hypothetical sightings of wolves in Grand Teton National Park.

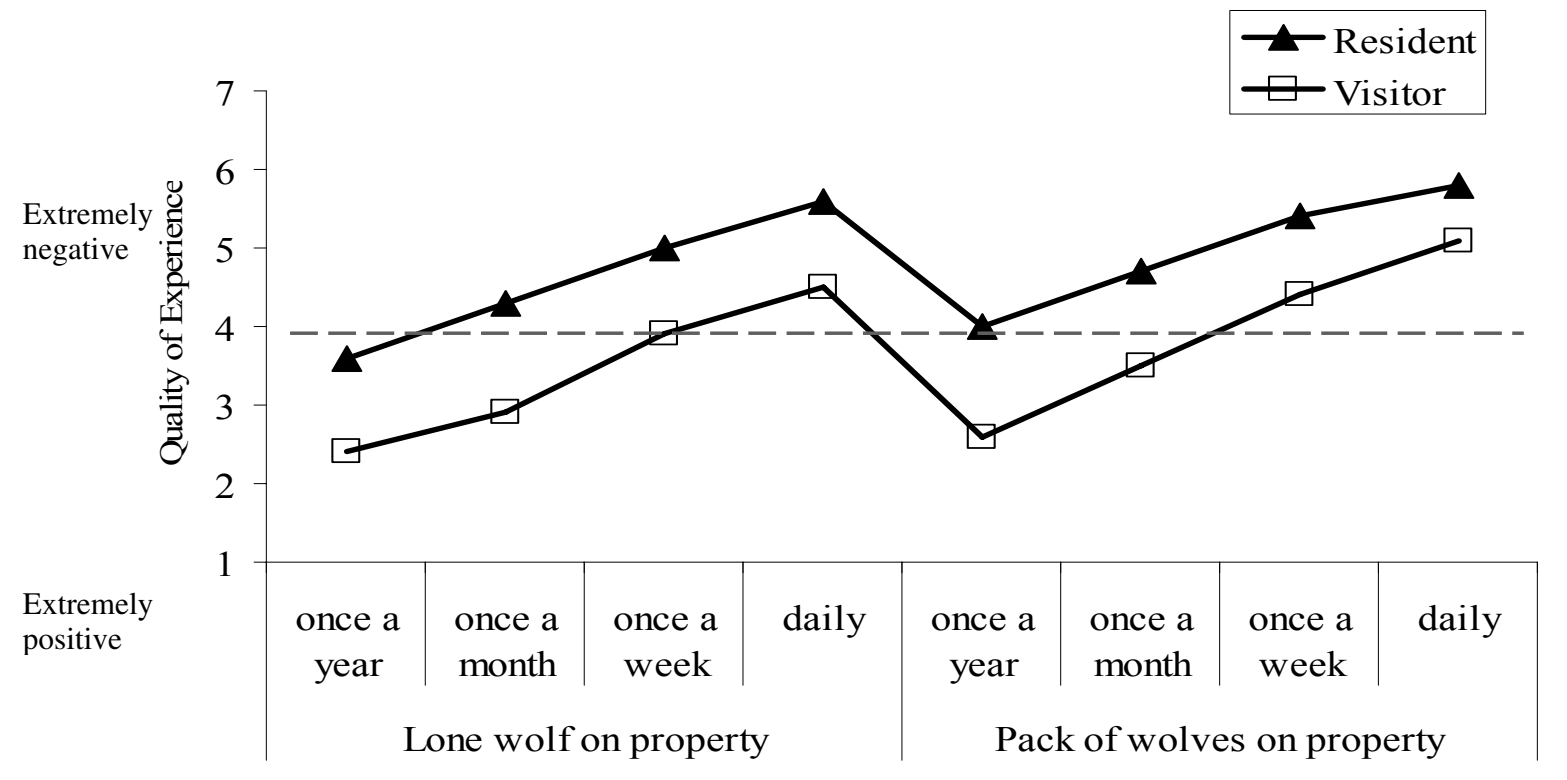

Figure 10. Average quality of experience level for various hypothetical sightings of wolves on own land. 


\section{Visitation and Experiences in Grand Teton National Park}

Nearly all local residents surveyed (94\%) had visited GRTE before and frequently (13 times on average; Table 16), but the majority of these visits, within 100 miles from their homes, were single day trips. Park visitor respondents had visited the park 5.1 times, on average (Table 17), and the majority (51\%) stayed for three days or longer. When describing their trip to GRTE, the majority of visitors reported that GRTE was one of several destinations (61\%). It was the primary or final destination for $28 \%$ of park visitors.

Table 16. Visitation in Grand Teton National Park: Local residents.

\begin{tabular}{lc}
\hline Local resident park experiences & $\%$ \\
\hline Have you ever visited Grand Teton National Park? & 94 \\
$\quad$ Yes & 6 \\
No & 63 \\
How long was your latest visit to Grand Teton National Park? & 18 \\
1 day visit only & 19 \\
2 day visit & 13.4 times on average \\
3 day visit or more
\end{tabular}

Table 17. Visitation in Grand Teton National Park: Park visitors.

\begin{tabular}{lc}
\hline Visitor park experiences & $\%$ \\
\hline For this trip Grand Teton National Park was... & 28 \\
$\quad$ Your primary and final destination & 61 \\
One of several destinations & 11 \\
A stop or a side trip on the way to another destination & \\
How long was your latest visit to Grand Teton National Park? & 27 \\
1 day visit only & 22 \\
2 day visit & 51 \\
3 day visit or more & 5.1 times on average \\
\hline How many times have you visited Grand Teton National Park?
\end{tabular}

The majority of residents listed viewing scenery (37\%) or driving for pleasure $(17 \%)$ as their primary purpose for their most recent visit to the park. Similar to local residents, park visitors listed viewing scenery (39\%) as their primary activity in the park. However, unlike residents, park visitors listed hiking (17\%), and wildlife viewing (12\%) as their next most popular park activities, rather than driving for pleasure $(3 \%$, Table 18$)$. 
Table 18. Local resident and park visitor's activities while in Grand Teton National Park.

\begin{tabular}{lcc}
\hline Activities in Grand Teton National Park & Local resident (\%) & Park visitor (\%) \\
\hline $\begin{array}{l}\text { During your last visit to the park what was the } \\
\text { primary purpose of your visit? }\end{array}$ & \\
View scenery & 37 & 39 \\
Driving for pleasure & 17 & 3 \\
Hiking & 8 & 17 \\
Wildlife viewing & 7 & 12 \\
Camping (developed campground) & 6 & 8 \\
Fishing & 4 & 2 \\
Backcountry camping & 3 & 3 \\
Canoeing or boating (lake) & 3 & 1 \\
Rock climbing & 3 & 3 \\
Canoeing or boating (river) & 2 & 2 \\
Horseback riding & 2 & $<1$ \\
Photography & 1 & 3 \\
Bicycling/mountain biking & 1 & $<1$ \\
Ranger led activities/programs & $<1$ & $<1$ \\
Other & 6 & 6 \\
\hline
\end{tabular}

\section{Judgments of Responsibility Model}

The potential interrelationships among judgments of responsibility, emotions, and acceptance of management actions for human-wolf conflict situations are illustrated in Figure 11. Detailed discussion of two-way correlations among these variables are included in Appendices $E$ (Responsibility Judgments $X$ Management Acceptability); F (Responsibility Judgments $X$ Emotions about Wolves); and G (Emotions about Wolves $X$ Management Acceptability). Each of these analyses is based on a series of hypothesized relationships among these variables.

First, we proposed that persons who placed primary responsibility, in human-wolf encounters, upon the individual involved would be more accepting of management actions that impacted that individual than of management actions that had more impact upon the wolves (Appendix E). Conversely, persons who placed primary responsibility upon one of the wildlife management agencies would be more likely to accept management impacting the wolves and less accepting of actions that impacted the individual involved. Since respondents to these surveys placed most responsibility with either the individual involved or with the US Fish and Wildlife Service, correlations with these two entities are the basis for these discussions.

The relationships between judgments of responsibility and management acceptability are shown to be as proposed (Tables E-1 through E-6). Survey respondents who put primary responsibility with the individual did accept management actions that affected those involved individuals more than actions that would affect the wolves. Positive correlations with individual management actions were "minimally" to "typically" correlated for hiker scenarios, and "substantially" correlated for rancher scenarios (see Vaske and others, 2002'). Management actions impacting the wolves were rejected by this respondent group at typical levels for hiker scenarios (Tables E-1 and E-2) and from typical to substantial levels for rancher scenarios.

\footnotetext{
${ }^{1}$ These authors recommend the following clarification of correlations found in social science research, since the range of what is statistically significant is rather great: $0.1=$ minimal correlation; 0.3 is at a level typical in social science; $0.5=$ substantial correlation.
} 
Respondents who held the FWS as primarily responsible showed the hypothesized reverse pattern: impact on the hiker rejected, impact on the wolves accepted at typical levels; for ranch scenarios (Tables E-3, 4, \& 5), rancher-impacting management alternatives were rejected (e.g. move or remove the cattle), while the lethal, "kill the wolves" alternative was accepted consistently across scenarios at levels between typical and substantial.

The second interrelationship we examined was between judgments of responsibility and emotions about wolves (Appendix F). For this interrelationship, we hypothesized that persons who held the individual responsible, in human-wolf encounters, would tend to be more sympathetic towards wolves but would feel less anger or fear towards wolves. Conversely, we predicted that persons who held the FWS more responsible would show a reverse pattern of emotions: less sympathy towards wolves and more anger and fear towards them.

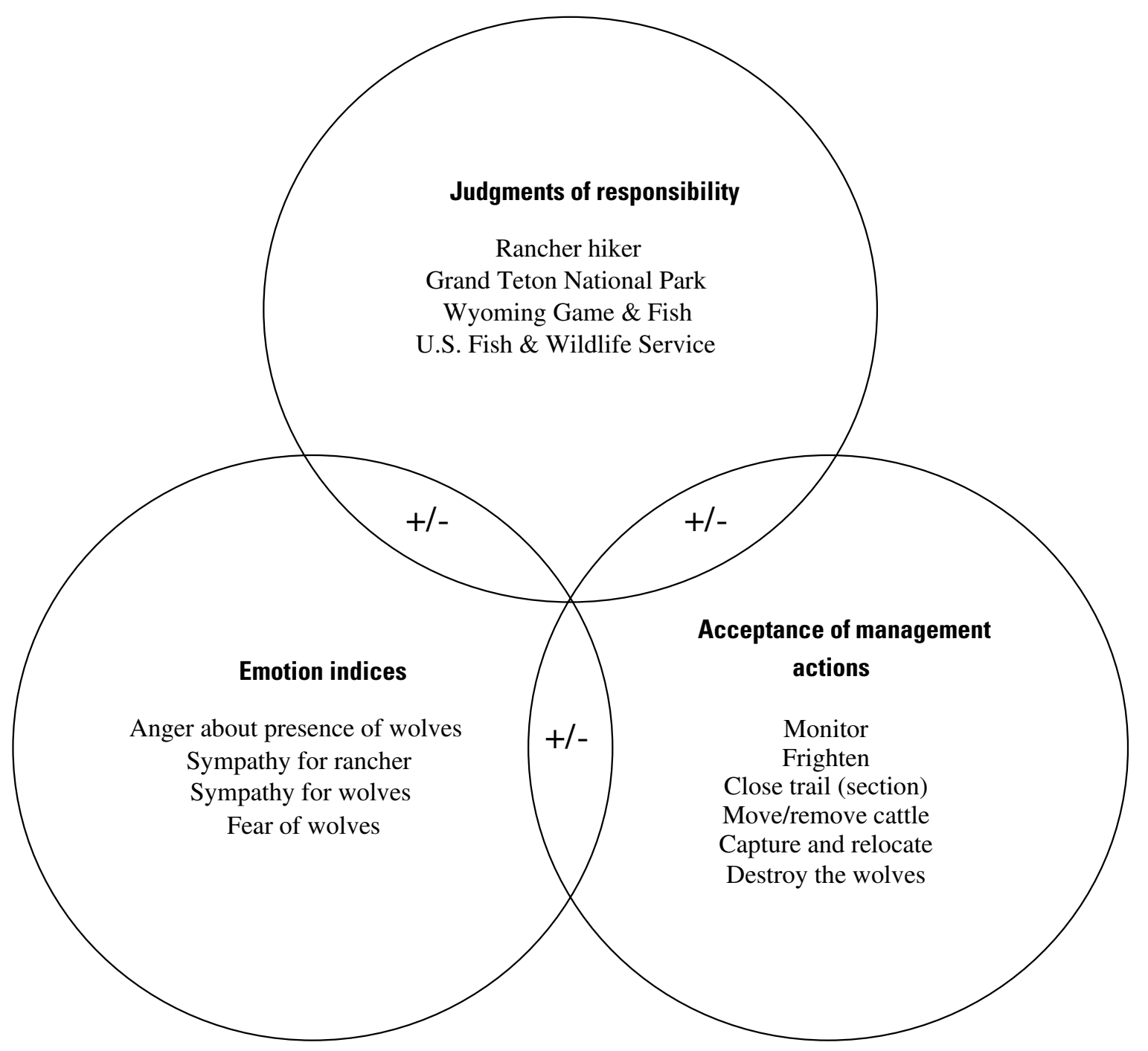

Figure 11. Judgments of responsibility conceptual model showing potential relationships among three variables included in the six hypothetical human-wolf interaction scenarios. 
For those who held hikers to be responsible, sympathy for wolves was correlated positively and fear of wolves was correlated negatively, at about typical levels (Tables F-1 and F-2). Anger about wolves was rated lower more strongly - near substantial for Scenario 1 (Table F-1). Those who held the FWS responsible in hiker encounters felt near-substantial anger about wolves, typical rejection of sympathy for wolves, but rather minimal fear of wolves.

For predation and near predation encounters with livestock and pets, Scenarios 2, 3, 4, and 6 (Tables F-3 to F-6), persons who held the individual responsible felt sympathy towards wolves at typical or higher levels (.31 to .41); rejected fear of wolves at typical levels (-.22 to -.36); and more strongly rejected anger about wolves, at or near substantial levels for 3 of the 4 scenarios (Tables F-3, 5, and 6). These respondents did not feel sympathy for the rancher involved, especially for encounters on grazing allotments within the park $(-0.49$ to -0.50 ; Tables F-3 and F-5). Respondents who held the FWS responsible in these encounters felt sympathy for the rancher, felt anger about wolves being present (both at typical levels); rejected sympathy towards wolves (typical), and expressed some fear of wolves (between minimal and typical levels). We noted earlier that "Fear of Wolves" was jointly felt by both local residents and park visitors, but this emotion shows differentiation between the "individual responsible" and "FWS responsible" sample groups.

Finally, we examined the interrelationship between emotions about wolves and the acceptance of alternative management actions (Appendix G). For this, we hypothesized that as a person feels more sympathy for wolves, the less likely they will be to accept management actions that impact the wolves. On the reverse side, as persons feel more sympathy for the individual involved (hiker, rancher, per owner), the less likely they will be to accept actions that impact the individual. Regarding fear and anger toward wolves, as these feelings increase, the likelihood of accepting managements that are invasive to the wolves would also increase.

For the hiking scenarios, the positive (sympathy) and negative (anger and fear) emotions towards wolves were tested, but not sympathy for the hiker. Sympathy and anger towards wolves had opposite patterns: anger about wolves correlated with capture and relocate the wolves (.33 to .44 , typical + ) and negatively correlated with closing trails or trail sections (-.26 to -.38, typical; Tables G-1 and G-2). Those sympathizing with the wolves were positive towards closing trails (.34 to .42 , typical +) while rejecting capture and release (-.21 to -.32). Fear of wolves correlated with the same $+/$ - pattern as anger about wolves, but at lower correlation rates.

In situations of predation or near-predation (Tables G-3 to G-6), correlations with emotions really became high, especially in relation to the lethal management alternative. Those who felt sympathy for the rancher and who felt anger about wolves being present rejected every management option except "capture and release" (and even that was not always positive), and "destroy the wolves involved" at levels consistently above substantial (.56 to .73). Conversely, those who felt sympathy towards the wolves only rejected capture and release in one in-park situation (Scenario 2, Table G-3), but rejected "kill the wolves involved" across the board, again at very high levels of correlation (-.64 to -.73; Tables G-3 to G-6). Clearly, emotions about wolves have a very strong relationship with decisions about whether or not wolves, involved in encounters with people or their property, should be killed.

\section{Summary of Judgments of Responsibility Model Results}

Overall, the hypothesized relationships among the three variables for the conceptual model of responsibility were supported. In considering the interrelationships among judgments of responsibility, acceptance of management actions, and emotions (Figure 11), two aspects bear consideration. First, the interrelationships are demonstrated among respondents attributing responsibility primarily to two entities: the individual involved or the USFWS. The low levels of attributed responsibility for the park and for WYG\&F do not support many strong statistical 
relationships. Second, the hypotheses listed predict relationships among judgments, emotions and management acceptance, but they do not define the direction of cause and effect. Emotions are more basic to human values, so the flow of relationship is more likely to be from emotion to judgment and to acceptance than in the reverse direction.

The purpose of these two relationship charts (Figures 12 and 13) is to reposition the interaction model to incorporate some of the correlations discussed here. Hopefully, these charts will allow going deeper, beyond the surface, in dealing with the public groups with interests at stake. For example, Group $X$ shows by their letters that they deplore putting wolves down for any reason - depredation or other, what does that mean? These persons are expressing sympathy for wolves, and probably hold the individuals involved in wolf encounters as more responsible than any of the management agencies. They are more likely to accept actions taken on the human side of encounters such as trail closures or moving livestock out of harms way as the appropriate means of resolving human-wolf conflict.

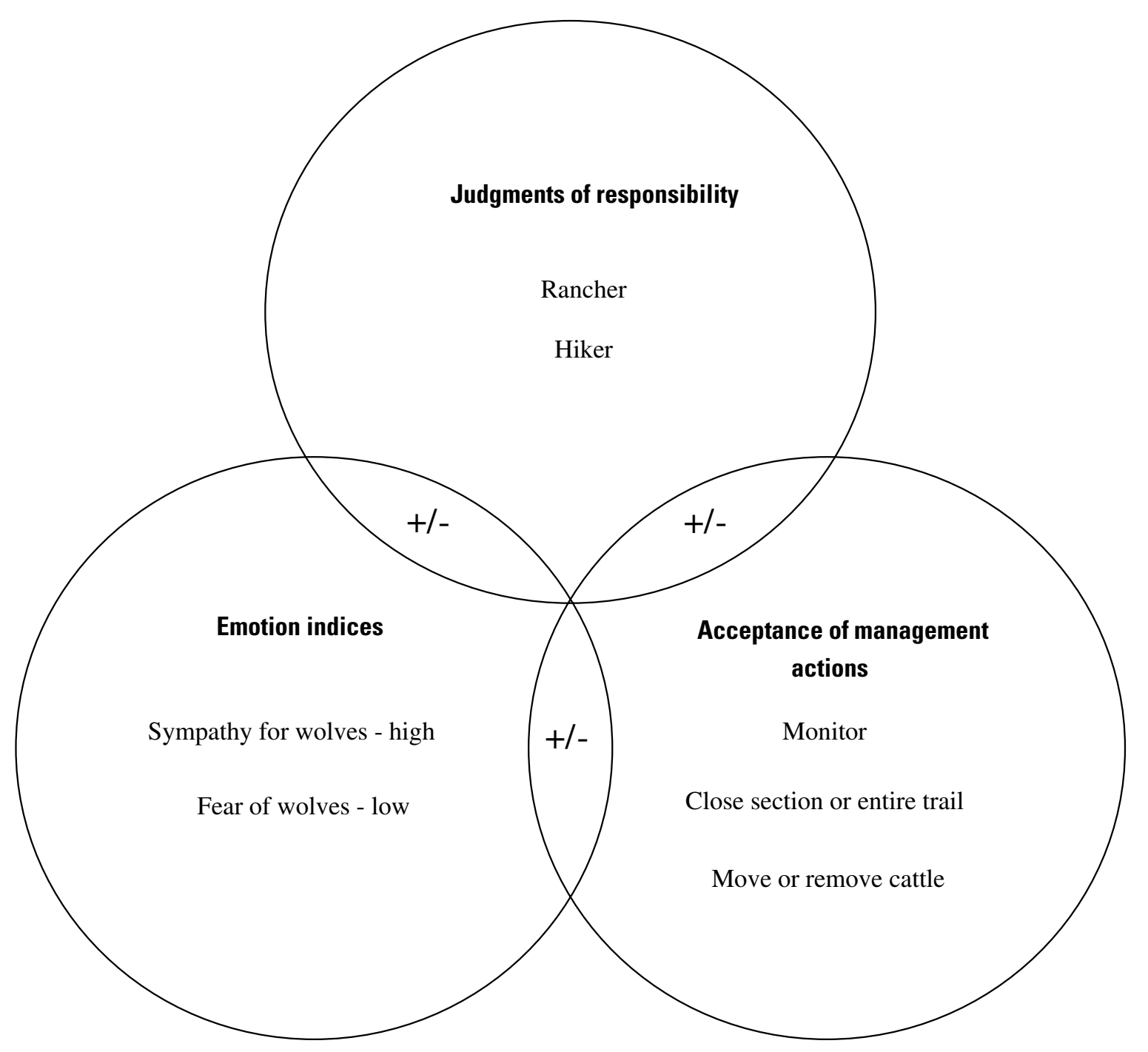

Figure 12. Judgments of responsibility/emotions/management acceptance model for persons who hold the individual primarily responsible in human wolf encounters. 
Group Y insists that the wildlife agencies (USFWS/WYG\&F) are responsible for humanwolf encounters, what does that imply? These people are more likely to sympathize with the rancher, pet owner, or hiker than with the wolves, and they are more likely to accept moving the wolves or destroying them than moving or removing the livestock or closing trail sections. In addition, they may be more prone to anger or fear about wolves or the fact that wolves have been brought into their living environment.

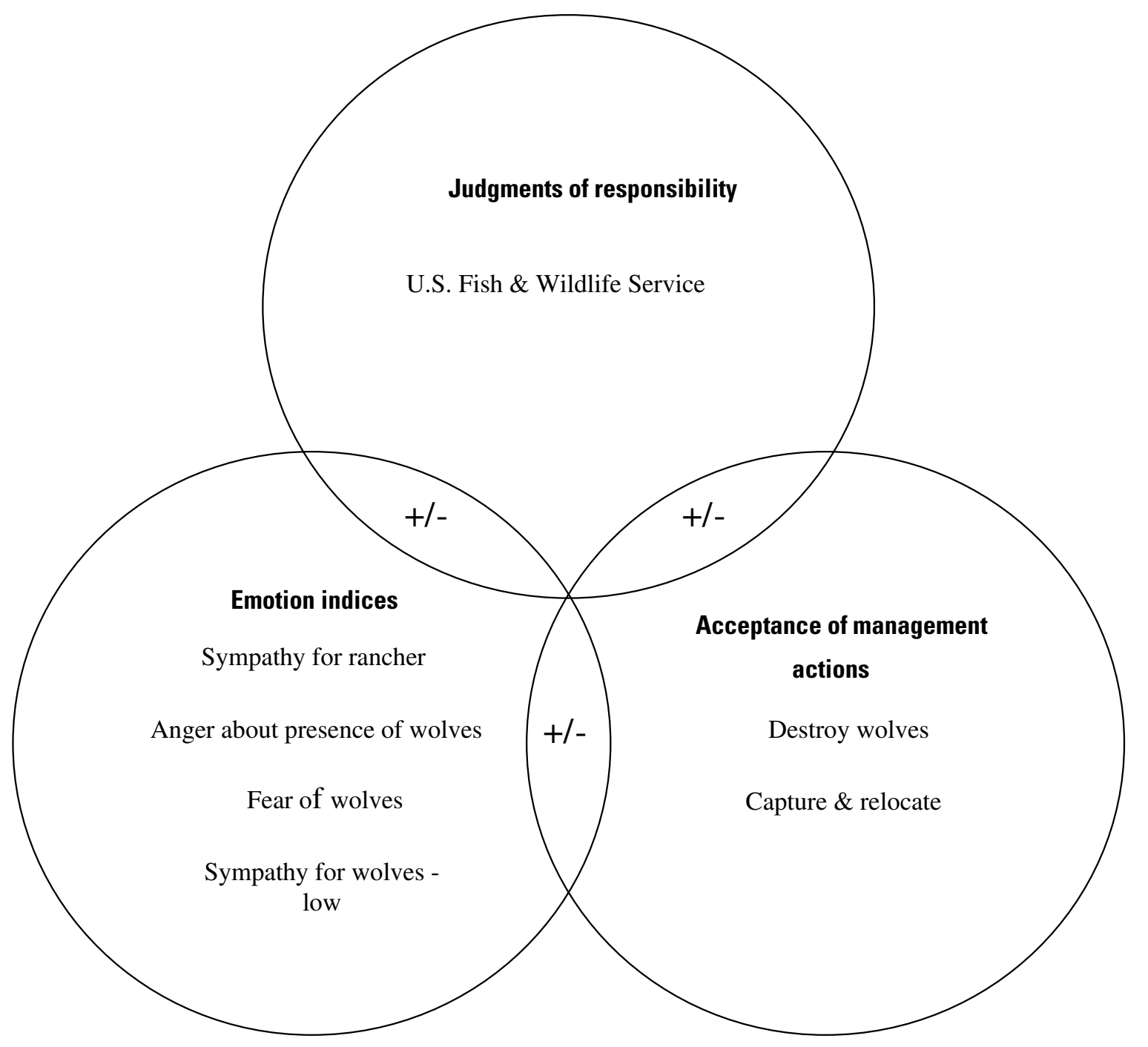

Figure 13. Judgments of responsibility/emotions/management acceptance model for persons who hold agencies responsible in human wolf encounters.

\section{Acceptance of Lethal Management Action}

As pointed out earlier (see pages 18-19, Table 10), the management option of killing the wolf or wolves involved in an encounter with livestock or pets was the strongest distinguishing action among all those presented. In the model interaction discussion, "kill the wolves" was the strongest interacting management variable with the emotion classes and in distinguishing between local resident and park visitor acceptance. Therefore, we tested the "wolf-kill norm" variable we created against emotion classes (Table 19) and against several demographic variables (Table 20). 
Persons who never selected the "kill the wolves" management option tended to be more sympathetic toward wolves, whereas those who always chose "kill the wolves" were sympathetic towards the rancher, and felt both anger and fear towards wolves. Both anger about wolves and sympathy towards wolves showed substantial measures of association, sympathy for rancher has a typical level of association. This can be interpreted as "the emotions of anger or sympathy for wolves are most likely to be related to decisions about whether it is acceptable to use lethal means to control wolf predation."

Table19. Wolf-kill norm compared with aggregate emotion classes.

\begin{tabular}{lcccc}
\hline & $\begin{array}{c}\text { Sympathy for } \\
\text { rancher }\end{array}$ & $\begin{array}{c}\text { Anger about } \\
\text { wolves }\end{array}$ & Fear of wolves & $\begin{array}{c}\text { Sympathy for } \\
\text { wolves }\end{array}$ \\
\hline Never kill wolves & $3.19^{\mathrm{a}}$ & 2.43 & 3.11 & 3.63 \\
Sometimes kill wolves & 3.87 & 3.28 & 3.51 & 2.59 \\
Always kill wolves & 4.58 & 4.16 & 4.00 & 1.66 \\
Eta measures of association $^{\mathrm{b}}$ & .348 & .511 & .174 & .484 \\
\hline
\end{tabular}

${ }^{\mathrm{a}}$ Values are mean aggregate response for emotion class by each wolf-kill norm group. Scales for emotion items, aggregated here into emotion classes, were from $1=$ strongly disagree to $5=$ strongly agree.

${ }^{b}$ Eta measures of association: .1 = minimal association, $.3=$ typical association, $.5=$ substantial association

Demographic variables listed in Table 20 all show significant associations with the management norms of never - and always kill the wolves involved. Men clearly are more prone to opting for killing the wolves than are women. Although the overall survey sample was skewed towards male respondents (63.5\% male), nevertheless, $82 \%$ of the always kill column is significant at the $p<.001$ level. People with college education or higher are much more likely to never select kill the wolves (85\%) than are people with high school levels or lower. Also, persons with lower household incomes are more likely to always select kill the wolves than people with household incomes above $\$ 75,000$. Age was a continuous value variable, rather than categorical, so this was tested with an ANOVA rather than a Chi Square test. Although statistically significant at the .05 level, age was less closely associated with this norm variable.

Table 20. Demographic variables compared with wolf-kill norm.

\begin{tabular}{llcccc}
\hline \multicolumn{2}{l}{ Demographic } & Never kill wolf (\%) & Always kill wolf (\%) & Chi square value & Significance level \\
\hline \multirow{2}{*}{ Sex } & Male & $53.5^{\text {a }}$ & 82.2 & 66.0 & $p<.001$ \\
\hline \multirow{2}{*}{ Education } & Female & 46.5 & 17.8 & \multirow{2}{*}{78.7} & $p<.001$ \\
& To high school & 15.1 & 37.9 & \multirow{2}{*}{40.4} & \multirow{2}{*}{0.001} \\
\hline \multirow{2}{*}{ Income } & $<\$ 75 \mathrm{~K}$ & 84.9 & 62.1 & 68.2 & $p<.05$ \\
\hline \multirow{2}{*}{ Age } & College \& higher & $575 \mathrm{~K}$ & 46.4 & 31.8 & 53.1 years \\
\hline
\end{tabular}

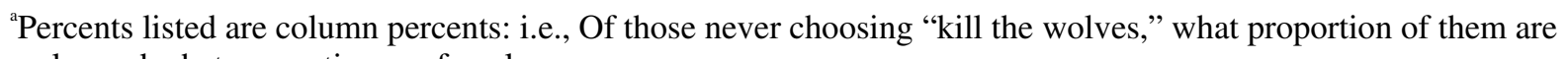
males and what proportion are females.

${ }^{\mathrm{b}}$ Age was recorded as a continuous variable and therefore is reported as what is the average age of respondents never or always selecting "kill the wolves involved." Age was not as strongly related. 


\section{Conclusions: Implications for Managers}

\section{Demographics}

In extrapolating these results to larger populations, it is important to bear in mind just what these samples represent. First, they are quite different from each other and different from census records in gender. More men than women responded to the surveys, and far more male local residents responded. This bias becomes critical, for example, when considering responses such as lethal management options: only $18 \%$ of those who always selected the action, "Kill the wolves" were women. As is very often the case, visitors to the park are not fully representative of the national population; a disproportionate percentage of visitors are Caucasian. Although our local resident sample included a portion of the Wind River Indian Reservation, it only included the western side of the Reservation which is less populated, so the American Indian difference may be more a factor of boundary than response rate. Also typical of national park surveys, the visitors were more highly educated and with higher incomes than the national average.

\section{Responsibility}

An unexpected result of this survey is the high degree to which park visitors attributed responsibility to the individuals involved in a wolf encounter or loss of animals to predation. These individuals (i.e., hikers, ranchers, and pet owners) were assigned the highest level of responsibility for all encounters by park visitors, and for the hikers in the park by local residents as well. This category was assigned the highest overall average responsibility across all scenarios. The USFWS is second highest in overall attributed responsibility, and the highest assigned by the local resident sample. Both LR and PV attributed more responsibility to the FWS in off-park depredation encounters than in comparable encounters within the park. The off-park livestock predation scenario was where the FWS received the highest responsibility by both samples. This off-park/in-park pattern is true for attributed responsibility to the WYG\&F as well, although at half the levels attributed to the FWS. Also, ranchers with grazing allotments within the park were held more responsible than was the off-park rancher, which may have some implications about the perceived legitimacy of park grazing rights. Again, the parallel lines of the graphs in Figure 8 show important information. First, when individual responsibility is up, agency responsibility is down, and vice versa. Second, PV and LR samples consistently differentiated from one wolf encounter context to another.

GRTE is held to be less responsible (20\% overall) than the individual or the USFWS, especially for encounters outside park boundaries. Park visitors tended to attribute slightly more responsibility to GRTE than local residents, but for in-park encounters, the park was attributed only about one-fourth of the responsibility, and outside the park less than one-fifth. The highest responsibility (29\%) attributed to the GRTE was for the wolves denning near the trail, by the park visitors. The WYG\&F is pretty well "left off the hook," receiving a fifth of assigned responsibility or less across all scenarios; local residents attributed slightly more responsibility to WYG\&F than visitors.

An important message for resource managers is that neither park visitors nor local residents, at least in the year 2003, made any distinction between management responsibilities when the wolves were listed as endangered vs. when they were depicted as delisted; no pattern of shifting responsibility from the federal to the state wildlife agencies is shown.

\section{Management Options}

Visitors consistently were more willing than local residents to list "monitor the situation" as an acceptable management action, especially where no depredation was reported. Also, in 
scenarios involving livestock or pets, visitors were significantly more accepting of "frighten the wolves away" than local residents, and more accepting than locals of alternatives that removed the temptation to the wolves, e.g., "close the trail" or "move the cattle away." Local residents were significantly more accepting of "destroy the wolves involved" than visitors, for each scenario that offered that option. Visitors, as a group, never got to accepting "destroy wolves" in their ratings. Both residents and visitors tended to accept the alternative of capturing and relocating the wolves in depredation situations, but not for hiking trail encounters. Land ownership had more influence on preferred management actions for visitors than for residents. Visitors found "move the remaining cattle" an acceptable management action, local residents did not. But the strongest difference in management option acceptance was visitors preferred nonlethal remedies while residents were more willing to accept lethal ones. Residents and visitors agreed that frightening wolves away from their den within the park was unacceptable.

\section{Emotions}

Park managers are already quite well aware that visitors to the park differ from local residents in their attitudes and feelings about wolves. Indeed, for some aspects of wolf-livestock encounters, residents and visitors disagreed profoundly. Residents expressed anger and upset with livestock being lost to wolves; visitors expressed their anger and upset about wolves being destroyed because of such losses. PV were quite strong in their sympathy towards wolves, LR tended to be angry about their presence. However, residents and park visitors were in agreement on some elements, especially that having some level of fear towards wolves was understandable. Both groups tended to feel sympathy towards ranchers who suffered losses of livestock to wolf predation.

\section{Experience with Wolves}

Residents living within 100 miles of Jackson Hole reported more wolf sightings and rated themselves as moderately more knowledgeable about wolves than did the visitors. When rating hypothetical sightings of wolves, two strong patterns emerge. First, visitors rate these encounters as significantly more positive than residents. Second, the positive appeal of the encounters described - both in a recreational setting and on one's own property - consistently declines as proximity to wolves increases and as both number of wolves and frequency of occurrence increase: i.e.; Seeing a wolf or wolves at some distance is a positive experience, but not if it happens too often or too close to home.

\section{Responsibility Model}

Persons who feel strong sympathy for wolves tend to hold individuals involved in human/wolf encounters responsible. These same persons are more likely to accept management actions that would impinge upon the individual involved (rancher, hiker, pet owner) than actions that impact the wolves. Park visitors are more likely to fall into this category than are local residents of the Jackson Hole region.

Persons who feel anger about the presence of wolves, and more fear of wolves, tend to hold the agencies, especially the U.S. Fish and Wildlife Service, more responsible. These persons are also more likely to feel sympathy for the rancher who looses livestock to wolves than their counterparts listed above. This group is more accepting of management actions that would impact the wolves than those actions that would affect the individual involved. This group is especially more accepting of lethal management actions. Local residents are more likely to fall into this category. 
Although there is a significant relationship between location (PV vs. LR) and willingness to accept lethal controls of wolves, there is a much stronger relationship between acceptance of that option and emotional position. People highly sympathetic toward wolves are much more likely to never select "destroy the wolves;" People angry about wolves being present are much more likely to accept the management option, "destroy the wolves," every time it is offered.

\section{References Cited}

Brown-Nuñez, C. and Taylor, J.G., 2002, Americans' attitudes toward wolves and wolf reintroduction: An annotated bibliography: USGS Information Technology Report United States Geological Survey/BRD/ITR-2002-0002, U.S. Government Printing Office, Denver, $\mathrm{CO}$.

Cromley, C., 1997, Preliminary assessment of attitudes and knowledge of Jackson Hole residents toward grizzly bears and wolves in Teton County, Report submitted to Grand Teton National Park, National Elk Refuge, Northern Rockies Conservation Cooperative, Yale University.

Dillman, D.A., 2000, Mail and internet surveys: The tailored design method ( $\left.2^{\text {nd }} e d.\right)$, New York, John Wiley and Sons.

Harlow, S.S., 2001, Judgments of responsibility and acceptance of management actions following human-wildlife conflict situations, M.S. Thesis, Department of Natural Resources Recreation and Tourism, Colorado State University, Fort Collins, CO.

National Park Service., 2004a, Grand Teton National Park facts, http://www.nps.gov/grte/pphtml/facts.html, Accessed on June 7, 2004.

National Park Service, 2004b, http://www.nps.gov/grte/wolf/biolo.htm, Accessed on June 7, 2004.

Neter, J., Kutner, M.H., Nachtsheim, C.J., and Wasserman, W., 1996, Applied linear statistical models $\left(4^{\text {th }}\right.$ ed. $)$, Chicago, Irwin.

Nunnally, J.C., 1978, Psychometric theory ( $2^{\text {nd }}$ ed.), New York, McGraw-Hill.

Schaberl, J., 1998, Voyageurs challenge: Protect wildlife and provide visitor access: Natural Resource Year in Review-1997, National Park Service, Department of Interior, http://www2.nature.nps.gov/YearInReview/yr_rvw97/chapter07/to_chapter07_a02.html, Accessed on June 15, 2005.

Smith, D.W., Stahler, D.R., and Guernsey, D.S., 2004, Yellowstone wolf project: Annual report, 2003, National Park Service, Yellowstone Center for Resources, Yellowstone National Park, Wyoming, YCR-NR-2004-04.

U.S. Census Bureau, 2005, Population estimate for Teton County, Wyoming, http://factfinder.census.gov/servlet/SAFFPopulation?_sse=onand_lang $=$ enand_state $=04000 U$ S56and_cityTown=teton20countyand_county=teton20countyand_zip=, Accessed on June 20, 2005.

U.S. Fish and Wildlife Service, 2004, http://mountain-prairie.USFWS.gov/pressrel/04-43.htm, Accessed on June 7, 2004.

U.S. Fish and Wildlife Service, Nez Perce Tribe, National Park Service, and USDA Wildife Services, 2004, Rocky Mountain wolf recovery 2003 annual report, T. Meier, ed. USFWS, Ecological Services, 100 N. Park, Suite 320, Helena, MT.

Weiner, B., 1995, Judgments of responsibility: A foundation for a theory of social conduct, New York, The Guilford Press.

Vaske, J.J., Gliner, J.A., and Morgan, G.A., 2002, Communicating judgments about practical significance: Effect size, confidence intervals and odds ratios, Human Dimensions of Wildlife, v. 7 , no. 4 , p. 287-300. 


\section{Appendix A. Onsite Visitor Survey}

\section{ÆUSGS}

\section{Public Perceptions of Wolf Management in the Southern Greater Yellowstone Area}

Hello. My name is

I I am working with the U.S. Geological Survey, helping to conduct a public survey about wolves in Grand Teton National Park and the surrounding area. Do you have a couple of minutes for a few questions?

Since their reintroduction in 1995 to Yellowstone National Park, wolves have successfully colonized areas within and around Grand Teton National Park. As the wolf population continues to grow in this area, the potential for conflicts with human activities and property also increases, requiring management remedies.

Grand Teton National Park, and the U.S. Geological Survey, would like your opinion about the management and care of this wolf population. By participating in this study you have the opportunity to express how you feel about wolf management issues in and around Grand Teton National Park.

First, we are interested in any experiences you may have had with wolves. Responding to this short survey is completely voluntary and your answers will always be kept confidential.

Would you please tell me about personal experiences, if any, you have had with wolves ...

1. Have you ever seen wolves, or a single wolf, in the wild? YES NO

IF YES - How many times have you seen wolves in the wild? \# times.

IF NO - Go to Question 3

2. How many times (if any) have you seen wolves in Grand Teton National Park? \# times.

3. Do you consider yourself to be knowledgeable about wolves? (Please rate yourself on this scale)

\begin{tabular}{ccccc}
1 & 2 & 3 & 4 & 5 \\
\hline $\begin{array}{c}\text { Not at all } \\
\text { knowledgeable }\end{array}$ & & & & $\begin{array}{c}\text { Very } \\
\text { knowledgeable }\end{array}$
\end{tabular}

We have a 12-page mail-out survey to explore public knowledge, feelings, and preferences about wolves in the Southern Greater Yellowstone area. Would you be willing to fill out one of these surveys if we mailed one to you? Again, responding to this survey is completely voluntary and your answers will be kept confidential. (If YES - complete name and address information below.)

Name

Street Address

\begin{tabular}{lll}
\hline City & State & Zip Code \\
\hline
\end{tabular}

Phone Number

E-mail address 


\section{Appendix B. Mailed Visitor Survey}

\section{‡USGS \\ science for a changing world \\ Public Perceptions of Wolf Management Actions \\ In the Southern \\ Greater Yellowstone Area}

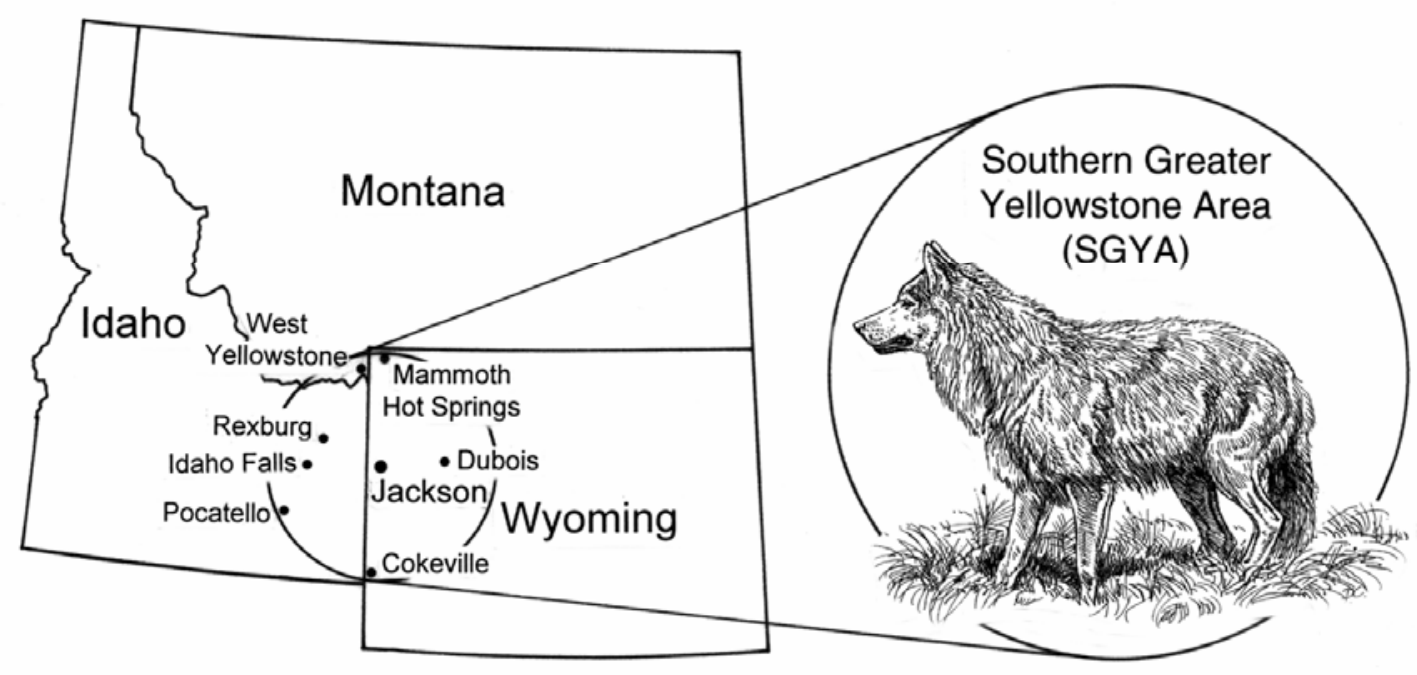

All your responses will be kept strictly confidential... Your participation is very much appreciated.

Thank you for your time. 


\section{Public Perceptions of Wolf Management in the Southern Greater Yellowstone Area}

In 1995 the Gray Wolf was re-introduced into Yellowstone National Park in an attempt to re-establish a healthy population of this animal. Since that time the wolves have successfully colonized areas surrounding Yellowstone National Park. In this survey, we are concerned with the wolves that have denned and reproduced in the Southern Greater Yellowstone Area (SGYA) - the Jackson Hole area of western Wyoming which includes Grand Teton National Park, the National Elk Refuge, portions of Bridger-Teton National Forest, and the town of Jackson. The U.S. Fish and Wildlife Service list the wolves from this reintroduction as an "endangered species, experimental population". That means the wolves currently are protected, but if some damage to livestock or other human property occurs wolves involved may be destroyed. The wolf population in the SGYA will remain an endangered species, experimental population, until the wolf population in the Rocky Mountain Recovery Area (MT, ID, WY) increases to 30 breeding pairs. At that point, this population could be removed from the endangered species list. However, as the wolf population continues to grow in this area, the potential for conflicts with human activities and property also increases, requiring management remedies. Responsible wildlife management strives to meet the needs of both the wildlife populations being managed and the concerns of the public. Out of concern for public interest in the management and care of this wolf population, Grand Teton National Park in conjunction with the United States Geological Survey would like to give you the opportunity to have input into how this wolf population should be managed under different conditions.

This survey is designed to provide you with the chance to express how you feel about wolf management issues in and around the SGYA. We are interested in what you believe. The best answers are the ones that most closely reflect your own feelings and beliefs.

Please answer all the questions in the survey; it takes about 15 minutes to complete. When you are finished, place the survey in the enclosed, stamped, self-addressed return envelope and mail it back to us.

If you have questions concerning this survey, please contact Dr. Jonathan G. Taylor at the Fort Collins Science Center, U.S. Geological Survey, 2150 C Centre Ave., Fort Collins, CO 80526 Phone: 970 226-9438 or e-mail: Jonathan_Taylor@USGS.GOV

PRIVACY ACT and PAPERWORK REDUCTION ACT statement:

16 U.S.C. 1a-7 authorizes collection of this information. This information will be used by park managers to better serve the public. Response to this request is voluntary. No action may be taken against you for refusing to supply the information requested. Your name is requested for follow-up mailing purposes only. When analysis of the questionnaire is completed, all name and address files will be destroyed. Thus permanent data will be anonymous. Data collected through visitor surveys may be disclosed to the Department of Justice when relevant to litigation or anticipated litigation, or to appropriate Federal, State, local or foreign agencies responsible for investigating or prosecuting a violation of law. An agency may not conduct or sponsor, and a person is not required to respond to, a collection of information unless it displays a currently valid OMB control number.

Burden estimate statement: Public reporting for this form is estimated to average 16 minutes per response. Direct comments regarding the burden estimate or any other aspect of this form to the Information Collection Clearance Officer, WASO Administrative Program Center, National Park Service, 1849 C Street, Washington, D.C. 20240.

OMB Control Number: 1024-0224 (NPS \#03-038)

Expiration Date: 03/31/2004 


\section{SECTION I.}

The following are hypothetical situations that describe possible human-wolf encounters in the Southern Greater Yellowstone Area (SGYA). Different natural resource agencies take part in the management of any conflicts that may occur between wolves and human activities or property. Many different factors influence public opinion about who is responsible for wolves in any conflict situations that may arise. Possible factors include:

- If the encounter occurred on private or public land (LOCATION);

- The type of human-wolf encounter (ENCOUNTER); and

- Whether the local wolf population is listed as an endangered species or removed from the endangered species list (STATUS OF WOLVES).

In addition to these factors, public acceptance of management actions taken to reduce human-wolf conflicts is of equal importance to natural resource managers. Following each scenario are several potential management actions that might be used to remedy the situation.

Scenarios 1 though 3 describe hypothetical situations where the wolves involved are LISTED AS AN ENDANGERED SPECIES, EXPERIMENTAL POPULATION.

Scenario 1.

- LOCATION: On a popular backcountry hiking trail in Grand Teton National Park.

- ENCOUNTER: A hiker sees several wolves feeding on a dead deer close to the trail. The wolves seem reluctant to leave their kill.

- STATUS OF THE WOLVES: Listed as an endangered species, experimental population.

In order to prevent ANY POTENTIAL conflict between wolves and human activity, which could result from the situation described above, what proportion of RESPONSIBILITY would you assign to the following:

The hiker

Grand Teton National Park

Wyoming Game \& Fish Department

U.S. Fish and Wildlife Service

Other

TOTAL responsibility

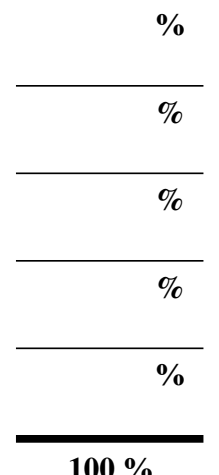

$100 \%$

Based on this encounter how ACCEPTABLE or UNACCEPTABLE is it for managers to take each of the following actions? (Please Circle the number that best describes your level of acceptance for each action.).

\begin{tabular}{|c|c|c|c|c|c|c|c|}
\hline Management Action & $\begin{array}{c}\text { Highly } \\
\text { Unacceptable }\end{array}$ & Unacceptable & $\begin{array}{c}\text { Somewhat } \\
\text { Unacceptable }\end{array}$ & $\begin{array}{c}\text { No } \\
\text { Opinion }\end{array}$ & $\begin{array}{l}\text { Somewhat } \\
\text { Acceptable }\end{array}$ & Acceptable & $\begin{array}{c}\text { Highly } \\
\text { Acceptable }\end{array}$ \\
\hline $\begin{array}{l}\text { Monitor the situation to } \\
\text { determine if the wolves } \\
\text { will cause any concern. }\end{array}$ & 1 & 2 & 3 & 4 & 5 & 6 & 7 \\
\hline $\begin{array}{l}\text { Frighten the wolves away } \\
\text { using non-lethal methods. }\end{array}$ & 1 & 2 & 3 & 4 & 5 & 6 & 7 \\
\hline $\begin{array}{l}\text { Capture and relocate the } \\
\text { wolves involved. }\end{array}$ & 1 & 2 & 3 & 4 & 5 & 6 & 7 \\
\hline $\begin{array}{l}\text { Close only the section of } \\
\text { the hiking trail that the } \\
\text { wolves are near. }\end{array}$ & 1 & 2 & 3 & 4 & 5 & 6 & 7 \\
\hline $\begin{array}{l}\text { Close the entire hiking trail } \\
\text { until the wolves have left } \\
\text { the area. }\end{array}$ & 1 & 2 & 3 & 4 & 5 & 6 & 7 \\
\hline
\end{tabular}


Scenario 2.

- LOCATION: Federal grazing allotment within Grand Teton National Park.

- ENCOUNTER: A pack of wolves has been chasing cattle from a small herd from time to time over the past 2 weeks. The wolves have not killed any cattle.

- STATUS OF THE WOLVES: Listed as an endangered species, experimental population.

For the event that happened, in the scenario described above, what proportion of RESPONSIBILITY would you assign to the following:

The rancher who owns the cattle

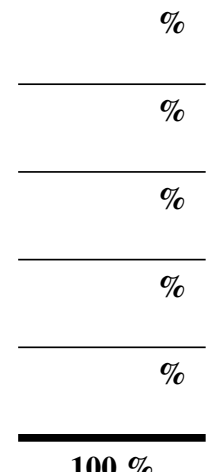

$100 \%$

TOTAL responsibility

Grand Teton National Park

Wyoming Game \& Fish Department

U.S. Fish and Wildlife Service

Other
$\%$

Based on this encounter how ACCEPTABLE or UNACCEPTABLE is it for managers to take each of the following actions? (Please Circle the number that best describes your level of acceptance for each action.).

\begin{tabular}{|c|c|c|c|c|c|c|c|}
\hline Management Action & $\begin{array}{c}\text { Highly } \\
\text { Unacceptable }\end{array}$ & Unacceptable & $\begin{array}{c}\text { Somewhat } \\
\text { Unacceptable }\end{array}$ & $\begin{array}{c}\text { No } \\
\text { Opinion }\end{array}$ & $\begin{array}{l}\text { Somewhat } \\
\text { Acceptable }\end{array}$ & Acceptable & $\begin{array}{c}\text { Highly } \\
\text { Acceptable }\end{array}$ \\
\hline $\begin{array}{l}\text { Monitor the situation to } \\
\text { determine if the wolves will } \\
\text { cause further concern. }\end{array}$ & 1 & 2 & 3 & 4 & 5 & 6 & 7 \\
\hline $\begin{array}{l}\text { Frighten the wolves away } \\
\text { using non-lethal methods. }\end{array}$ & 1 & 2 & 3 & 4 & 5 & 6 & 7 \\
\hline $\begin{array}{l}\text { Capture and relocate the } \\
\text { wolves involved. }\end{array}$ & 1 & 2 & 3 & 4 & 5 & 6 & 7 \\
\hline $\begin{array}{l}\text { Move the cattle to another area } \\
\text { of the grazing allotment. }\end{array}$ & 1 & 2 & 3 & 4 & 5 & 6 & 7 \\
\hline $\begin{array}{l}\text { Remove the cattle in question } \\
\text { from the park. }\end{array}$ & 1 & 2 & 3 & 4 & 5 & 6 & 7 \\
\hline Destroy the wolves involved. & 1 & 2 & 3 & 4 & 5 & 6 & 7 \\
\hline
\end{tabular}


Scenario 3.

- LOCATION: On private ranch land next to Grand Teton National Park.

- ENCOUNTER: A local rancher in the Jackson-Hole area has reported the loss of several cattle within the last month due to wolf kills.

- $\quad$ STATUS OF WOLVES: Listed as an endangered species, experimental population.

For the event that happened, in the scenario described above, what proportion of RESPONSIBILITY would you assign to the following:

The rancher

Grand Teton National Park

Wyoming Game \& Fish Department

U.S. Fish and Wildlife Service

Other

TOTAL responsibility

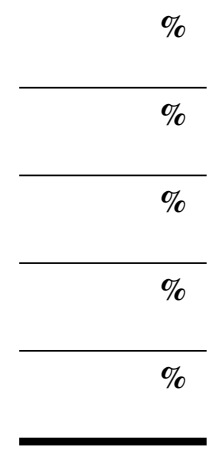

$100 \%$

Based on this encounter how ACCEPTABLE or UNACCEPTABLE is it for managers to take each of the following actions? (Please Circle the number that best describes your level of acceptance for each action.).

\begin{tabular}{|c|c|c|c|c|c|c|c|}
\hline Management Action & $\begin{array}{c}\text { Highly } \\
\text { Unacceptable }\end{array}$ & Unacceptable & $\begin{array}{c}\text { Somewhat } \\
\text { Unacceptable }\end{array}$ & $\begin{array}{c}\text { No } \\
\text { Opinion }\end{array}$ & $\begin{array}{l}\text { Somewhat } \\
\text { Acceptable }\end{array}$ & Acceptable & $\begin{array}{c}\text { Highly } \\
\text { Acceptable }\end{array}$ \\
\hline $\begin{array}{l}\text { Monitor the situation to } \\
\text { determine if the wolves will } \\
\text { cause further loss. }\end{array}$ & 1 & 2 & 3 & 4 & 5 & 6 & 7 \\
\hline $\begin{array}{l}\text { Frighten the wolves away } \\
\text { using non-lethal methods. }\end{array}$ & 1 & 2 & 3 & 4 & 5 & 6 & 7 \\
\hline $\begin{array}{l}\text { Capture and relocate the } \\
\text { wolves involved. }\end{array}$ & 1 & 2 & 3 & 4 & 5 & 6 & 7 \\
\hline $\begin{array}{l}\text { Destroy the wolves } \\
\text { involved. }\end{array}$ & 1 & 2 & 3 & 4 & 5 & 6 & 7 \\
\hline
\end{tabular}


Scenarios 4 though 6 describe hypothetical situations where the wolves involved are NO LONGER LISTED AS AN

ENDANGERED SPECIES.

Scenario 4.

- LOCATION: On private land next to Grand Teton National Park.

- ENCOUNTER: A homeowner has recently had their pet dog killed by a wolf.

- STATUS OF THE WOLVES: Wolf numbers have increased; they are no longer listed as an endangered species.

For the event that happened, in the scenario described above, what proportion of RESPONSIBILITY would you assign to the following:

The homeowner

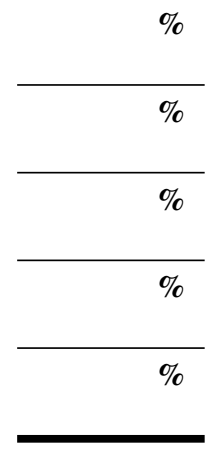

TOTAL responsibility

$100 \%$

Based on this encounter how ACCEPTABLE or UNACCEPTABLE is it for managers to take each of the following actions? (Please Circle the number that best describes your level of acceptance for each action.)

\begin{tabular}{|c|c|c|c|c|c|c|c|}
\hline Management Action & $\begin{array}{c}\text { Highly } \\
\text { Unacceptable }\end{array}$ & Unacceptable & $\begin{array}{c}\text { Somewhat } \\
\text { Unacceptable }\end{array}$ & $\begin{array}{c}\text { No } \\
\text { Opinion }\end{array}$ & $\begin{array}{l}\text { Somewhat } \\
\text { Acceptable }\end{array}$ & Acceptable & $\begin{array}{c}\text { Highly } \\
\text { Acceptable }\end{array}$ \\
\hline $\begin{array}{l}\text { Monitor the situation to } \\
\text { determine if the wolf will } \\
\text { cause further loss. }\end{array}$ & 1 & 2 & 3 & 4 & 5 & 6 & 7 \\
\hline $\begin{array}{l}\text { Frighten the wolf away } \\
\text { using non-lethal methods. }\end{array}$ & 1 & 2 & 3 & 4 & 5 & 6 & 7 \\
\hline $\begin{array}{l}\text { Capture and relocate the } \\
\text { wolf involved. }\end{array}$ & 1 & 2 & 3 & 4 & 5 & 6 & 7 \\
\hline Destroy the wolf involved. & 1 & 2 & 3 & 4 & 5 & 6 & 7 \\
\hline
\end{tabular}


Scenario 5.

- LOCATION: On a popular backcountry hiking trail in Grand Teton National Park.

- ENCOUNTER: A hiker sees several wolves and their pups near what appears to be a denning site. As the hiker watches, the wolves become aware of the hiker's presence.

- STATUS OF THE WOLVES: Wolf numbers have increased; they are no longer listed as an endangered species.

IN ORDER TO PROTECT THE WOLVES' DENNING SITE, from any potential human influence, which could result from the situation described above, what proportion of RESPONSIBILITY would you assign to the following:

The hiker

Grand Teton National Park

Wyoming Game \& Fish Department

U.S. Fish and Wildlife Service

Other

TOTAL responsibility

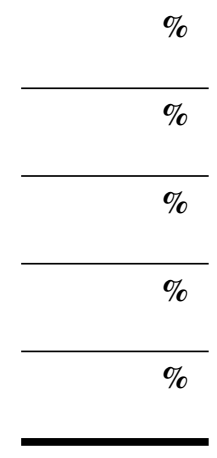

$100 \%$

Based on this encounter how ACCEPTABLE or UNACCEPTABLE is it for managers to take each of the following actions? (Please Circle the number that best describes your level of acceptance for each action.).

\begin{tabular}{|c|c|c|c|c|c|c|c|}
\hline Management Action & $\begin{array}{c}\text { Highly } \\
\text { Unacceptable }\end{array}$ & Unacceptable & $\begin{array}{c}\text { Somewhat } \\
\text { Unacceptable }\end{array}$ & $\begin{array}{c}\text { No } \\
\text { Opinion } \\
\end{array}$ & $\begin{array}{l}\text { Somewhat } \\
\text { Acceptable }\end{array}$ & Acceptable & $\begin{array}{c}\text { Highly } \\
\text { Acceptable }\end{array}$ \\
\hline $\begin{array}{l}\text { Monitor the situation to } \\
\text { determine if the wolves } \\
\text { will cause any concern. }\end{array}$ & 1 & 2 & 3 & 4 & 5 & 6 & 7 \\
\hline $\begin{array}{l}\text { Frighten the wolves away } \\
\text { using non-lethal methods. }\end{array}$ & 1 & 2 & 3 & 4 & 5 & 6 & 7 \\
\hline $\begin{array}{l}\text { Capture and relocate the } \\
\text { wolves involved. }\end{array}$ & 1 & 2 & 3 & 4 & 5 & 6 & 7 \\
\hline $\begin{array}{l}\text { Close only the section of } \\
\text { the hiking trail that the } \\
\text { wolves are near. }\end{array}$ & 1 & 2 & 3 & 4 & 5 & 6 & 7 \\
\hline $\begin{array}{l}\text { Close the entire hiking trail } \\
\text { until the wolves have left } \\
\text { the area. }\end{array}$ & 1 & 2 & 3 & 4 & 5 & 6 & 7 \\
\hline
\end{tabular}


Scenario 6.

- LOCATION: Federal grazing allotment in Grand Teton National Park.

- ENCOUNTER: A cattle rancher has reported the loss of several cattle within the last month, killed by wolves.

- STATUS OF THE WOLVES: Wolf numbers have increased; they are no longer listed as an endangered species.

For the event that happened, in the scenario described above, what proportion of RESPONSIBILITY would you assign to the following:

The cattle rancher

Grand Teton National Park

Wyoming Game \& Fish Department

U.S. Fish and Wildlife Service

Other

TOTAL responsibility

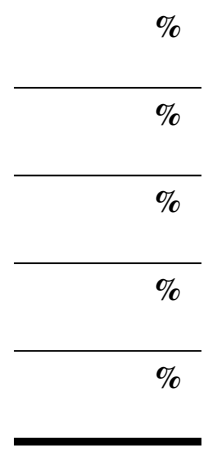

$100 \%$

Based on this encounter how ACCEPTABLE or UNACCEPTABLE is it for managers to take the following actions?

(Please Circle the number that best describes your level of acceptance for each action.)

\begin{tabular}{|c|c|c|c|c|c|c|c|}
\hline Management Action & $\begin{array}{c}\text { Highly } \\
\text { Unacceptable }\end{array}$ & Unacceptable & $\begin{array}{c}\text { Somewhat } \\
\text { Unacceptable }\end{array}$ & $\begin{array}{c}\text { No } \\
\text { Opinion }\end{array}$ & $\begin{array}{l}\text { Somewhat } \\
\text { Acceptable }\end{array}$ & Acceptable & $\begin{array}{c}\text { Highly } \\
\text { Acceptable }\end{array}$ \\
\hline $\begin{array}{l}\text { Monitor the situation to } \\
\text { determine if the wolves } \\
\text { will cause further concern. }\end{array}$ & 1 & 2 & 3 & 4 & 5 & 6 & 7 \\
\hline $\begin{array}{l}\text { Frighten the wolves away } \\
\text { using non-lethal methods. }\end{array}$ & 1 & 2 & 3 & 4 & 5 & 6 & 7 \\
\hline $\begin{array}{l}\text { Capture and relocate the } \\
\text { wolves involved. }\end{array}$ & 1 & 2 & 3 & 4 & 5 & 6 & 7 \\
\hline $\begin{array}{l}\text { Move the remaining cattle } \\
\text { to another area of the } \\
\text { grazing allotment. }\end{array}$ & 1 & 2 & 3 & 4 & 5 & 6 & 7 \\
\hline $\begin{array}{l}\text { Remove the remaining } \\
\text { cattle in question from the } \\
\text { park. }\end{array}$ & 1 & 2 & 3 & 4 & 5 & 6 & 7 \\
\hline $\begin{array}{l}\text { Destroy the wolves } \\
\text { involved. }\end{array}$ & 1 & 2 & 3 & 4 & 5 & 6 & 7 \\
\hline
\end{tabular}




\section{SECTION II.}

In the previous section, you indicated how acceptable it was to take certain management actions following situations depicting conflicts between wolves and human activities or property. In this section, please indicate how EFFECTIVE you feel each of the management options listed below would be in remedying those conflicts.

(Please Circle the number that best describes how effective you believe each action would be.)

\begin{tabular}{|c|c|c|c|c|c|}
\hline $\begin{array}{l}\text { The Conflict } \\
\text { Management Actions }\end{array}$ & $\begin{array}{l}\text { Not at all } \\
\text { Effective }\end{array}$ & $\begin{array}{l}\text { Somewhat } \\
\text { Effective }\end{array}$ & Effective & $\begin{array}{l}\text { Extremely } \\
\text { Effective }\end{array}$ & $\begin{array}{l}\text { Don’t } \\
\text { Know }\end{array}$ \\
\hline \multicolumn{6}{|l|}{ To prevent wolves from entering an area on private property... } \\
\hline Frightening devices, such as loud sirens and flashing lights & 1 & 2 & 3 & 4 & DK \\
\hline Electric fences & 1 & 2 & 3 & 4 & DK \\
\hline Guard dogs & 1 & 2 & 3 & 4 & DK \\
\hline Shooting at wolves with non-lethal rubber bullets & 1 & 2 & 3 & 4 & DK \\
\hline \multicolumn{6}{|l|}{$\begin{array}{l}\text { To avoid human- wolf disturbances within Grand Teton National } \\
\text { Park... }\end{array}$} \\
\hline $\begin{array}{l}\text { Closure of sections of hiking trails that are close to wolf denning } \\
\text { areas. }\end{array}$ & 1 & 2 & 3 & 4 & DK \\
\hline Closure of entire hiking trails that pass near wolf denning areas. & 1 & 2 & 3 & 4 & DK \\
\hline \multicolumn{6}{|l|}{$\begin{array}{l}\text { To reduce future threat to human property following instances of } \\
\text { conflict between wolves and human activities or property... }\end{array}$} \\
\hline Capture and relocation of an entire pack involved. & 1 & 2 & 3 & 4 & DK \\
\hline Capture and relocation of an individual wolf involved. & 1 & 2 & 3 & 4 & DK \\
\hline Destroy an individual wolf that was in a pack involved. & 1 & 2 & 3 & 4 & DK \\
\hline Destroy the breeding pair of wolves in a pack involved. & 1 & 2 & 3 & 4 & DK \\
\hline Destroy the entire pack involved. & 1 & 2 & 3 & 4 & DK \\
\hline
\end{tabular}

\section{SECTION III.}

People feel a variety of emotions when encountering wild animals or hearing about conflicts between people and wild animals. Please indicate below how strongly you agree or disagree with each of the following statements about different feelings towards wolves. (Please circle the appropriate number for each)

\begin{tabular}{|c|c|c|c|c|c|c|}
\hline & $\begin{array}{l}\text { Strongly } \\
\text { Disagree }\end{array}$ & Disagree & Neutral & Agree & $\begin{array}{c}\text { Strongly } \\
\text { Agree }\end{array}$ & Undecided \\
\hline $\begin{array}{l}\text { - I get angry when I learn that a wolf has destroyed } \\
\text { someone's livestock. }\end{array}$ & 1 & 2 & 3 & 4 & 5 & $\mathrm{U}$ \\
\hline $\begin{array}{l}\text { It does not anger me to know that pet dogs may be } \\
\text { attacked and killed by wild animals, such as } \\
\text { wolves. }\end{array}$ & 1 & 2 & 3 & 4 & 5 & $U$ \\
\hline $\begin{array}{l}\text { I don't understand why some people become angry } \\
\text { when wolves destroy livestock. }\end{array}$ & 1 & 2 & 3 & 4 & 5 & $\mathrm{U}$ \\
\hline $\begin{array}{l}\text { I don't think anyone should be afraid of wolves for } \\
\text { any reason. }\end{array}$ & 1 & 2 & 3 & 4 & 5 & $\mathrm{U}$ \\
\hline $\begin{array}{l}\text { - I would never worry about my safety in an area } \\
\text { that I knew had wolves. }\end{array}$ & 1 & 2 & 3 & 4 & 5 & $\mathrm{U}$ \\
\hline $\begin{array}{l}\text { I have sympathy for wolves that rely on livestock } \\
\text { for food. }\end{array}$ & 1 & 2 & 3 & 4 & 5 & $\mathrm{U}$ \\
\hline $\begin{array}{l}\text { - It angers me to learn that wolves may be destroyed } \\
\text { if they harass livestock but don't actually kill them. }\end{array}$ & 1 & 2 & 3 & 4 & 5 & $\mathrm{U}$ \\
\hline
\end{tabular}




\section{SECTION IV.}

People have many different ideas about what is a tolerable number of encounters to have with wild animals. Please indicate if it would be a positive, negative or neutral EXPERIENCE if you had the following encounters with wolves.

\begin{tabular}{|c|c|c|c|c|c|c|c|}
\hline & & $\begin{array}{l}\text { Strongly } \\
\text { Disagree } \\
\end{array}$ & Disagree & Neutral & Agree & $\begin{array}{l}\text { Strongly } \\
\text { Agree }\end{array}$ & Undecided \\
\hline - & $\begin{array}{l}\text { It saddens me to know that ranchers may suffer } \\
\text { the loss of their livestock due to wolf attacks. }\end{array}$ & 1 & 2 & 3 & 4 & 5 & $\mathrm{U}$ \\
\hline - & $\begin{array}{l}\text { I don't have any sympathy for wolves that are } \\
\text { destroyed for killing livestock. }\end{array}$ & 1 & 2 & 3 & 4 & 5 & $\mathrm{U}$ \\
\hline - & $\begin{array}{l}\text { It upsets me to learn that livestock has been } \\
\text { destroyed by re-introduced wolves. }\end{array}$ & 1 & 2 & 3 & 4 & 5 & $\mathrm{U}$ \\
\hline - & $\begin{array}{l}\text { I get angry with the National Park Service when I } \\
\text { hear that visitors in a national park may } \\
\text { encounter wolves. }\end{array}$ & 1 & 2 & 3 & 4 & 5 & $\mathrm{U}$ \\
\hline - & $\begin{array}{l}\text { I have no sympathy for ranchers who lose } \\
\text { livestock to wolf attacks. }\end{array}$ & 1 & 2 & 3 & 4 & 5 & $\mathrm{U}$ \\
\hline - & $\begin{array}{l}\text { I feel sorry for wolves when they are destroyed } \\
\text { for any reason. }\end{array}$ & 1 & 2 & 3 & 4 & 5 & $\mathrm{U}$ \\
\hline • & $\begin{array}{l}\text { I would never be fearful of a wolf if I saw one on } \\
\text { my property. }\end{array}$ & 1 & 2 & 3 & 4 & 5 & $\mathrm{U}$ \\
\hline - & $\begin{array}{l}\text { It frightens me when I hear about wolves killing a } \\
\text { pet dog }\end{array}$ & 1 & 2 & 3 & 4 & 5 & $\mathrm{U}$ \\
\hline - & $\begin{array}{l}\text { It scares me knowing that wolves are living in } \\
\text { Grand Teton National Park. }\end{array}$ & 1 & 2 & 3 & 4 & 5 & $\mathrm{U}$ \\
\hline$\bullet$ & $\begin{array}{l}\text { I understand why some people are fearful of } \\
\text { wolves }\end{array}$ & 1 & 2 & 3 & 4 & 5 & $\mathrm{U}$ \\
\hline
\end{tabular}

(Please circle the appropriate number for each experience.)

\begin{tabular}{|c|c|c|c|c|c|c|c|c|}
\hline $\begin{array}{l}\text { What type of experience would this } \\
\text { be for you? }\end{array}$ & $\begin{array}{l}\text { Extremely } \\
\text { Positive }\end{array}$ & Positive & $\begin{array}{c}\text { Somewhat } \\
\text { Positive }\end{array}$ & Neutral & $\begin{array}{l}\text { Somewhat } \\
\text { Negative }\end{array}$ & Negative & $\begin{array}{l}\text { Extremely } \\
\text { Negative }\end{array}$ & $\begin{array}{l}\text { Don't } \\
\text { Know }\end{array}$ \\
\hline \multicolumn{9}{|l|}{$\begin{array}{l}\text { 1. You are camping at Grand Teton } \\
\text { National Park and have seen a wolf } \\
\text { near the campground where you } \\
\text { are staying ... }\end{array}$} \\
\hline once? & 1 & 2 & 3 & 4 & 5 & 6 & 7 & DK \\
\hline twice? & 1 & 2 & 3 & 4 & 5 & 6 & 7 & DK \\
\hline several times? & 1 & 2 & 3 & 4 & 5 & 6 & 7 & DK \\
\hline \multicolumn{9}{|l|}{$\begin{array}{l}\text { 2. You see a lone wolf traveling across } \\
\text { your own property... }\end{array}$} \\
\hline once a year? & 1 & 2 & 3 & 4 & 5 & 6 & 7 & DK \\
\hline once a month? & 1 & 2 & 3 & 4 & 5 & 6 & 7 & DK \\
\hline once a week? & 1 & 2 & 3 & 4 & 5 & 6 & 7 & DK \\
\hline daily? & 1 & 2 & 3 & 4 & 5 & 6 & 7 & DK \\
\hline \multicolumn{9}{|l|}{$\begin{array}{l}\text { 3. You are hiking at Grand Teton } \\
\text { National Park and see a pack of } \\
\text { wolves in the distance... }\end{array}$} \\
\hline on one hike? & 1 & 2 & 3 & 4 & 5 & 6 & 7 & DK \\
\hline on two separate hikes? & 1 & 2 & 3 & 4 & 5 & 6 & 7 & DK \\
\hline on several hikes? & 1 & 2 & 3 & 4 & 5 & 6 & 7 & DK \\
\hline
\end{tabular}




\begin{tabular}{|c|c|c|c|c|c|c|c|c|}
\hline $\begin{array}{l}\text { What type of experience would this } \\
\text { be for you? }\end{array}$ & $\begin{array}{l}\text { Extremely } \\
\text { Positive }\end{array}$ & Positive & $\begin{array}{c}\text { Somewhat } \\
\text { Positive }\end{array}$ & Neutral & $\begin{array}{c}\text { Somewhat } \\
\text { Negative }\end{array}$ & Negative & $\begin{array}{c}\text { Extremely } \\
\text { Negative }\end{array}$ & $\begin{array}{l}\text { Don't } \\
\text { Know }\end{array}$ \\
\hline \multicolumn{9}{|l|}{$\begin{array}{l}\text { 4. You see a pack of wolves } \\
\text { traveling across your } \\
\text { property... }\end{array}$} \\
\hline once a year? & 1 & 2 & 3 & 4 & 5 & 6 & 7 & DK \\
\hline once a month? & 1 & 2 & 3 & 4 & 5 & 6 & 7 & DK \\
\hline once a week? & 1 & 2 & 3 & 4 & 5 & 6 & 7 & $\mathrm{DK}$ \\
\hline daily? & 1 & 2 & 3 & 4 & 5 & 6 & 7 & DK \\
\hline \multicolumn{9}{|l|}{$\begin{array}{l}\text { 5. You are hiking at Grand Teton } \\
\text { National Park and see a lone wolf } \\
\text { in the distance... }\end{array}$} \\
\hline on one hike? & 1 & 2 & 3 & 4 & 5 & 6 & 7 & $\mathrm{DK}$ \\
\hline on two separate hikes? & 1 & 2 & 3 & 4 & 5 & 6 & 7 & DK \\
\hline on several hikes? & 1 & 2 & 3 & 4 & 5 & 6 & 7 & DK \\
\hline
\end{tabular}

\section{SECTION V.}

Finally, we would like to ask you about your visit to Grand Teton National Park and your background.

The information you supply will remain completely confidential.

1. For this trip, Grand Teton National Park was. . . your primary and final destination. one of several destinations planned for this trip. a stop or a side trip on the way to another final destination.

\section{During this visit to GRAND TETON NATIONAL PARK, what was the PRIMARY purpose of your trip?}

(What motivated you to visit Grand Teton National Park?) (Check the one most important purpose for this trip)

\begin{tabular}{|c|c|c|}
\hline $\begin{array}{l}\text { Camping } \\
\text { (developed campground) }\end{array}$ & _ View Scenery & _Driving for pleasure \\
\hline $\begin{array}{l}\text { Backcountry camping } \\
\text { (undeveloped campground) }\end{array}$ & _Canoeing or boating (River) & _Ranger led activities/programs \\
\hline _Hiking & _Canoeing or boating (Lake) & Fishing \\
\hline _Wildlife viewing & __Rock climbing & _Bicycling/Mountain biking \\
\hline _Photography & _Horseback riding & Other \\
\hline
\end{tabular}

3. How many times have you visited Grand Teton National Park? \# times.

4. During the trip when you were contacted about this survey, how long was your visit to Grand Teton National Park ?

(Check one only)

1 day visit only

2 day visit

3 day visit or more 
5. If you were an overnight visitor in the SGYA, where did you stay? (check all that apply)

Camped in developed campground in the park _L Lodge or hotel in the park

_L Lodge or hotel outside of the park

Camped in the backcountry of the park

Camped in developed campground outside of the park

Other, please describe

6. Are you?

Male

Female

7. How old are you?

Years

8. In what ethnic group (A) and race (B) would you put yourself?

A. Ethnicity (select one)

Hispanic or Latino

NOT Hispanic or Latino

B. Race (select one or more)

American Indian or Alaska native (if yes: please answer question 9)

Asian

Black or African American

Native Hawaiian or other Pacific Islander

White

9. If you checked “American Indian”, please identify your tribal affiliation:

10. What is the highest level of education that you have achieved?

Less than high school diploma

High school diploma or GED
Technical/vocational degree

Some college
4 year college degree

Advanced degree beyond 4-year degree

11. What is your approximate annual household income before taxes?

Less than $\$ 10,000$

$\$ 25,000$ to $\$ 49,999$
$\$ 50,000$ to $\$ 74,999$

Country;
$\$ 125,000$ to $\$ 149,000$

$\$ 150,000$ or more

12. Where are you from?

$\$ 100,000$ to $\$ 124,999$

State or Province:

If from Wyoming, Montana, or Idaho, in what COUNTY do you reside? County

\section{How would you describe your current residence or community?}

a large city with 250,000 or more people a city with 100,000 to 249,999 people a small city with 50,000 to 99,999 people a town with 10,000 to 49,999 people

a small town/village with fewer than 10,000 people

a farm or rural area

Thank you for participating in this study. Your opinions are very valuable! 


\section{Appendix C. Mailed Resident Survey}

\section{₹USGS \\ Public Perceptions of Wolf Management Actions In the Southern Greater Yellowstone Area}

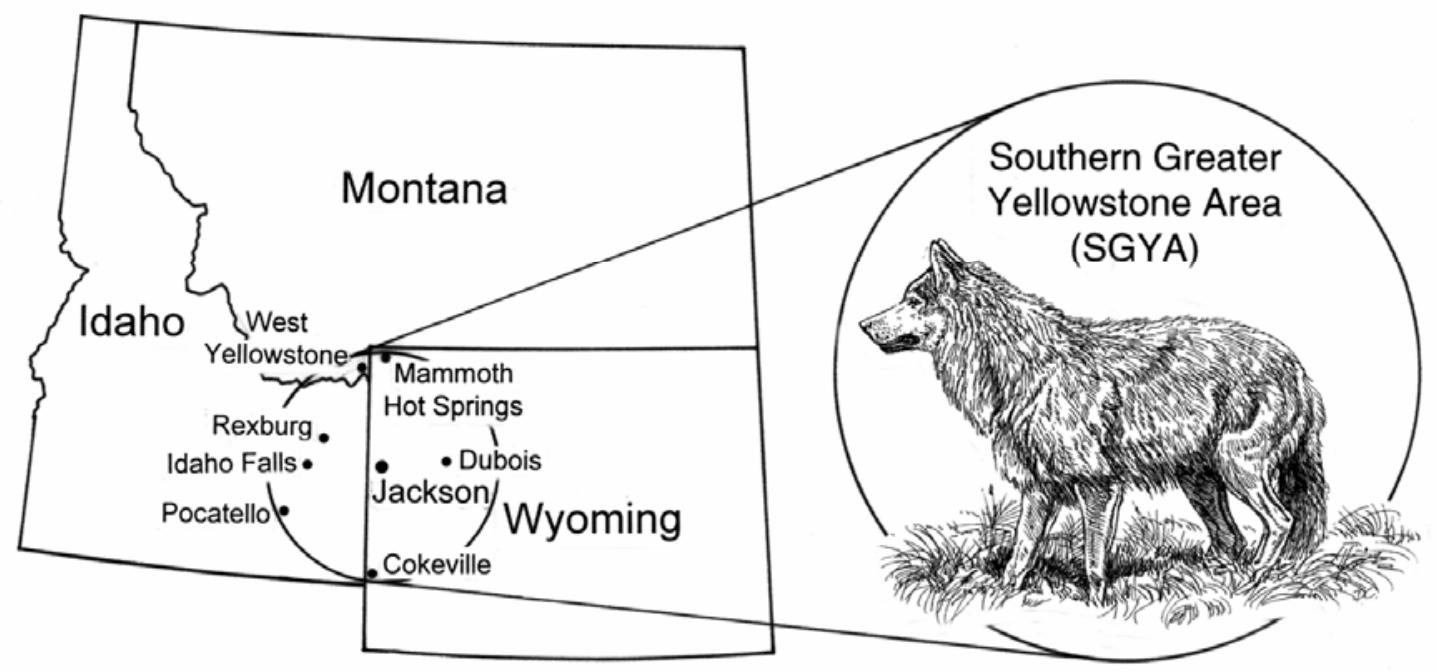

All your responses will be kept strictly confidential...

Your participation is very much appreciated.

Thank you for your time. 


\section{Public Perceptions of Wolf Management in the Southern Greater Yellowstone Area}

In 1995 the Gray Wolf was re-introduced into Yellowstone National Park in an attempt to re-establish a healthy population of this animal. Since that time the wolves have successfully colonized areas surrounding Yellowstone National Park. In this survey, we are concerned with the wolves that have denned and reproduced in the Southern Greater Yellowstone Area (SGYA) - the Jackson Hole area of western Wyoming which includes Grand Teton National Park, the National Elk Refuge, portions of Bridger-Teton National Forest, and the town of Jackson. The U.S. Fish and Wildlife Service list the wolves from this reintroduction as an "endangered species, experimental population". That means the wolves currently are protected, but if some damage to livestock or other human property occurs wolves involved may be destroyed. The wolf population in the SGYA will remain an endangered species, experimental population, until the wolf population in the Rocky Mountain Recovery Area (MT, ID, WY) increases to 30 breeding pairs. At that point, this population could be removed from the endangered species list. However, as the wolf population continues to grow in this area, the potential for conflicts with human activities and property also increases, requiring management remedies. Responsible wildlife management strives to meet the needs of both the wildlife populations being managed and the concerns of the public. Out of concern for public interest in the management and care of this wolf population, Grand Teton National Park in conjunction with the United States Geological Survey would like to give you the opportunity to have input into how this wolf population should be managed under different conditions.

This survey is designed to provide you with the chance to express how you feel about wolf management issues in and around the SGYA. We are interested in what you believe. The best answers are the ones that most closely reflect your own feelings and beliefs.

Please answer all the questions in the survey; it takes about 15 minutes to complete. When you are finished, place the survey in the enclosed, stamped, self-addressed return envelope and mail it back to us.

If you have questions concerning this survey, please contact Dr. Jonathan G. Taylor at the Fort Collins Science Center, U.S. Geological Survey, 2150 C Centre Ave., Fort Collins, CO 80526 Phone: 970 226-9438 or e-mail: Jonathan_Taylor@USGS.GOV

PRIVACY ACT and PAPERWORK REDUCTION ACT statement:

16 U.S.C. 1a-7 authorizes collection of this information. This information will be used by park managers to better serve the public. Response to this request is voluntary. No action may be taken against you for refusing to supply the information requested. Your name is requested for follow-up mailing purposes only. When analysis of the questionnaire is completed, all name and address files will be destroyed. Thus permanent data will be anonymous. Data collected through visitor surveys may be disclosed to the Department of Justice when relevant to litigation or anticipated litigation, or to appropriate Federal, State, local or foreign agencies responsible for investigating or prosecuting a violation of law. An agency may not conduct or sponsor, and a person is not required to respond to, a collection of information unless it displays a currently valid OMB control number.

Burden estimate statement: Public reporting for this form is estimated to average 16 minutes per response. Direct comments regarding the burden estimate or any other aspect of this form to the Information Collection Clearance Officer, WASO Administrative Program Center, National Park Service, 1849 C Street, Washington, D.C. 20240.

OMB Control Number: 1024-0224 (NPS \#03-038)

Expiration Date: 03/31/2004 


\section{SECTION I.}

The following are hypothetical situations that describe possible human-wolf encounters in the Southern Greater Yellowstone Area (SGYA). Different natural resource agencies take part in the management of any conflicts that may occur between wolves and human activities or property. Many different factors influence public opinion about who is responsible for wolves in any conflict situations that may arise. Possible factors include:

- If the encounter occurred on private or public land (LOCATION);

- The type of human-wolf encounter (ENCOUNTER); and

- Whether the local wolf population is listed as an endangered species or removed from the endangered species list (STATUS OF WOLVES).

In addition to these factors, public acceptance of management actions taken to reduce human-wolf conflicts is of equal importance to natural resource managers. Following each scenario are several potential management actions that might be used to remedy the situation.

Scenarios 1 though 3 describe hypothetical situations where the wolves involved are LISTED AS AN ENDANGERED SPECIES, EXPERIMENTAL POPULATION.

Scenario 1.

- LOCATION: On a popular backcountry hiking trail in Grand Teton National Park.

- ENCOUNTER: A hiker sees several wolves feeding on a dead deer close to the trail. The wolves seem reluctant to leave their kill.

- STATUS OF THE WOLVES: Listed as an endangered species, experimental population.

In order to prevent ANY POTENTIAL conflict between wolves and human activity, which could result from the situation described above, what proportion of RESPONSIBILITY would you assign to the following:

\begin{tabular}{lr} 
The hiker & $\%$ \\
Grand Teton National Park & $\%$ \\
\cline { 2 - 2 } Wyoming Game \& Fish Department & $\%$ \\
\hline U.S. Fish and Wildlife Service & $\%$ \\
\cline { 2 - 2 } Other & $\mathbf{1 0 0 \%}$
\end{tabular}

Based on this encounter how ACCEPTABLE or UNACCEPTABLE is it for managers to take each of the following actions? (Please Circle the number that best describes your level of acceptance for each action.).

\begin{tabular}{|c|c|c|c|c|c|c|c|}
\hline Management Action & $\begin{array}{c}\text { Highly } \\
\text { Unacceptable }\end{array}$ & Unacceptable & $\begin{array}{c}\text { Somewhat } \\
\text { Unacceptable }\end{array}$ & $\begin{array}{c}\text { No } \\
\text { Opinion }\end{array}$ & $\begin{array}{l}\text { Somewhat } \\
\text { Acceptable }\end{array}$ & Acceptable & $\begin{array}{c}\text { Highly } \\
\text { Acceptable }\end{array}$ \\
\hline $\begin{array}{l}\text { Monitor the situation to } \\
\text { determine if the wolves } \\
\text { will cause any concern. }\end{array}$ & 1 & 2 & 3 & 4 & 5 & 6 & 7 \\
\hline $\begin{array}{l}\text { Frighten the wolves away } \\
\text { using non-lethal methods. }\end{array}$ & 1 & 2 & 3 & 4 & 5 & 6 & 7 \\
\hline $\begin{array}{l}\text { Capture and relocate the } \\
\text { wolves involved. }\end{array}$ & 1 & 2 & 3 & 4 & 5 & 6 & 7 \\
\hline $\begin{array}{l}\text { Close only the section of } \\
\text { the hiking trail that the } \\
\text { wolves are near. }\end{array}$ & 1 & 2 & 3 & 4 & 5 & 6 & 7 \\
\hline $\begin{array}{l}\text { Close the entire hiking trail } \\
\text { until the wolves have left } \\
\text { the area. }\end{array}$ & 1 & 2 & 3 & 4 & 5 & 6 & 7 \\
\hline
\end{tabular}


Scenario 2.

- LOCATION: Federal grazing allotment within Grand Teton National Park.

- ENCOUNTER: A pack of wolves has been chasing cattle from a small herd from time to time over the past 2 weeks. The wolves have not killed any cattle.

- STATUS OF THE WOLVES: Listed as an endangered species, experimental population.

For the event that happened, in the scenario described above, what proportion of RESPONSIBILITY would you assign to the following:

The rancher who owns the cattle

Grand Teton National Park

Wyoming Game \& Fish Department

U.S. Fish and Wildlife Service

Other

TOTAL responsibility

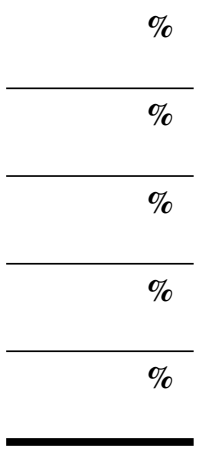

$100 \%$

Based on this encounter how ACCEPTABLE or UNACCEPTABLE is it for managers to take each of the following actions? (Please Circle the number that best describes your level of acceptance for each action).

\begin{tabular}{|c|c|c|c|c|c|c|c|}
\hline Management Action & $\begin{array}{c}\text { Highly } \\
\text { Unacceptable }\end{array}$ & Unacceptable & $\begin{array}{c}\text { Somewhat } \\
\text { Unacceptable }\end{array}$ & $\begin{array}{c}\text { No } \\
\text { Opinion }\end{array}$ & $\begin{array}{l}\text { Somewhat } \\
\text { Acceptable }\end{array}$ & Acceptable & $\begin{array}{c}\text { Highly } \\
\text { Acceptable }\end{array}$ \\
\hline $\begin{array}{l}\text { Monitor the situation to } \\
\text { determine if the wolves will } \\
\text { cause further concern. }\end{array}$ & 1 & 2 & 3 & 4 & 5 & 6 & 7 \\
\hline $\begin{array}{l}\text { Frighten the wolves away } \\
\text { using non-lethal methods. }\end{array}$ & 1 & 2 & 3 & 4 & 5 & 6 & 7 \\
\hline $\begin{array}{l}\text { Capture and relocate the } \\
\text { wolves involved. }\end{array}$ & 1 & 2 & 3 & 4 & 5 & 6 & 7 \\
\hline $\begin{array}{l}\text { Move the cattle to another } \\
\text { area of the grazing } \\
\text { allotment. }\end{array}$ & 1 & 2 & 3 & 4 & 5 & 6 & 7 \\
\hline $\begin{array}{l}\text { Remove the cattle in } \\
\text { question from the park. }\end{array}$ & 1 & 2 & 3 & 4 & 5 & 6 & 7 \\
\hline $\begin{array}{l}\text { Destroy the wolves } \\
\text { involved. }\end{array}$ & 1 & 2 & 3 & 4 & 5 & 6 & 7 \\
\hline
\end{tabular}


Scenario 3.

- LOCATION: On private ranch land next to Grand Teton National Park.

- ENCOUNTER: A local rancher in the Jackson-Hole area has reported the loss of several cattle within the last month due to wolf kills.

- $\quad$ STATUS OF WOLVES: Listed as an endangered species, experimental population.

For the event that happened, in the scenario described above, what proportion of RESPONSIBILITY would you assign to the following:

The rancher

Grand Teton National Park

Wyoming Game \& Fish Department

U.S. Fish and Wildlife Service

Other

TOTAL responsibility

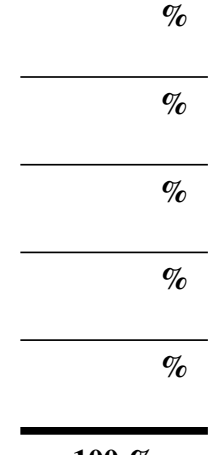

$100 \%$

Based on this encounter how ACCEPTABLE or UNACCEPTABLE is it for managers to take each of the following actions? (Please Circle the number that best describes your level of acceptance for each action.).

\begin{tabular}{|c|c|c|c|c|c|c|c|}
\hline Management Action & $\begin{array}{c}\text { Highly } \\
\text { Unacceptable }\end{array}$ & Unacceptable & $\begin{array}{c}\text { Somewhat } \\
\text { Unacceptable }\end{array}$ & $\begin{array}{c}\text { No } \\
\text { Opinion }\end{array}$ & $\begin{array}{l}\text { Somewhat } \\
\text { Acceptable }\end{array}$ & Acceptable & $\begin{array}{c}\text { Highly } \\
\text { Acceptable }\end{array}$ \\
\hline $\begin{array}{l}\text { Monitor the situation to } \\
\text { determine if the wolves will } \\
\text { cause further loss. }\end{array}$ & 1 & 2 & 3 & 4 & 5 & 6 & 7 \\
\hline $\begin{array}{l}\text { Frighten the wolves away } \\
\text { using non-lethal methods. }\end{array}$ & 1 & 2 & 3 & 4 & 5 & 6 & 7 \\
\hline $\begin{array}{l}\text { Capture and relocate the } \\
\text { wolves involved. }\end{array}$ & 1 & 2 & 3 & 4 & 5 & 6 & 7 \\
\hline $\begin{array}{l}\text { Destroy the wolves } \\
\text { involved. }\end{array}$ & 1 & 2 & 3 & 4 & 5 & 6 & 7 \\
\hline
\end{tabular}


Scenarios 4 though 6 describe hypothetical situations where the wolves involved are NO LONGER LISTED AS AN

ENDANGERED SPECIES.

Scenario 4.

- LOCATION: On private land next to Grand Teton National Park.

- ENCOUNTER: A homeowner has recently had their pet dog killed by a wolf.

- STATUS OF THE WOLVES: Wolf numbers have increased; they are no longer listed as an endangered species.

For the event that happened, in the scenario described above, what proportion of RESPONSIBILITY would you assign to the following:

The homeowner
Grand Teton National Park
Wyoming Game \& Fish Department

U.S. Fish and Wildlife Service

Other

TOTAL responsibility

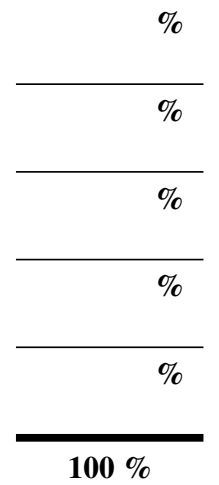

$100 \%$

Based on this encounter how ACCEPTABLE or UNACCEPTABLE is it for managers to take each of the following actions? (Please Circle the number that best describes your level of acceptance for each action.)

\begin{tabular}{|c|c|c|c|c|c|c|c|}
\hline Management Action & $\begin{array}{c}\text { Highly } \\
\text { Unacceptable }\end{array}$ & Unacceptable & $\begin{array}{c}\text { Somewhat } \\
\text { Unacceptable }\end{array}$ & $\begin{array}{c}\text { No } \\
\text { Opinion }\end{array}$ & $\begin{array}{l}\text { Somewhat } \\
\text { Acceptable }\end{array}$ & Acceptable & $\begin{array}{c}\text { Highly } \\
\text { Acceptable }\end{array}$ \\
\hline $\begin{array}{l}\text { Monitor the situation to } \\
\text { determine if the wolf will } \\
\text { cause further loss. }\end{array}$ & 1 & 2 & 3 & 4 & 5 & 6 & 7 \\
\hline $\begin{array}{l}\text { Frighten the wolf away } \\
\text { using non-lethal methods. }\end{array}$ & 1 & 2 & 3 & 4 & 5 & 6 & 7 \\
\hline $\begin{array}{l}\text { Capture and relocate the } \\
\text { wolf involved. }\end{array}$ & 1 & 2 & 3 & 4 & 5 & 6 & 7 \\
\hline Destroy the wolf involved. & 1 & 2 & 3 & 4 & 5 & 6 & 7 \\
\hline
\end{tabular}


Scenario 5.

- LOCATION: On a popular backcountry hiking trail in Grand Teton National Park.

- ENCOUNTER: A hiker sees several wolves and their pups near what appears to be a denning site. As the hiker watches, the wolves become aware of the hiker's presence.

- STATUS OF THE WOLVES: Wolf numbers have increased; they are no longer listed as an endangered species.

IN ORDER TO PROTECT THE WOLVES' DENNING SITE, from any potential human influence, which could result from the situation described above, what proportion of RESPONSIBILITY would you assign to the following:

The hiker

Grand Teton National Park

Wyoming Game \& Fish Department

U.S. Fish and Wildlife Service

Other

TOTAL responsibility
$\%$

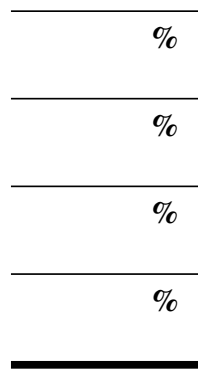

$100 \%$

Based on this encounter how ACCEPTABLE or UNACCEPTABLE is it for managers to take each of the following actions? (Please Circle the number that best describes your level of acceptance for each action.).

\begin{tabular}{|c|c|c|c|c|c|c|c|}
\hline Management Action & $\begin{array}{c}\text { Highly } \\
\text { Unacceptable }\end{array}$ & Unacceptable & $\begin{array}{c}\text { Somewhat } \\
\text { Unacceptable }\end{array}$ & $\begin{array}{c}\text { No } \\
\text { Opinion } \\
\end{array}$ & $\begin{array}{l}\text { Somewhat } \\
\text { Acceptable }\end{array}$ & Acceptable & $\begin{array}{c}\text { Highly } \\
\text { Acceptable }\end{array}$ \\
\hline $\begin{array}{l}\text { Monitor the situation to } \\
\text { determine if the wolves } \\
\text { will cause any concern. }\end{array}$ & 1 & 2 & 3 & 4 & 5 & 6 & 7 \\
\hline $\begin{array}{l}\text { Frighten the wolves away } \\
\text { using non-lethal methods. }\end{array}$ & 1 & 2 & 3 & 4 & 5 & 6 & 7 \\
\hline $\begin{array}{l}\text { Capture and relocate the } \\
\text { wolves involved. }\end{array}$ & 1 & 2 & 3 & 4 & 5 & 6 & 7 \\
\hline $\begin{array}{l}\text { Close only the section of } \\
\text { the hiking trail that the } \\
\text { wolves are near. }\end{array}$ & 1 & 2 & 3 & 4 & 5 & 6 & 7 \\
\hline $\begin{array}{l}\text { Close the entire hiking trail } \\
\text { until the wolves have left } \\
\text { the area. }\end{array}$ & 1 & 2 & 3 & 4 & 5 & 6 & 7 \\
\hline
\end{tabular}


Scenario 6.

- LOCATION: Federal grazing allotment in Grand Teton National Park.

- ENCOUNTER: A cattle rancher has reported the loss of several cattle within the last month, killed by wolves.

- STATUS OF THE WOLVES: Wolf numbers have increased; they are no longer listed as an endangered species.

For the event that happened, in the scenario described above, what proportion of RESPONSIBILITY would you assign to the following:

\begin{tabular}{lr} 
The cattle rancher & $\%$ \\
Grand Teton National Park & $\%$ \\
\cline { 2 - 2 } Wyoming Game \& Fish Department & $\%$ \\
\hline U.S. Fish and Wildlife Service & $\%$ \\
\cline { 2 - 2 } Other & $100 \%$
\end{tabular}

Based on this encounter how ACCEPTABLE or UNACCEPTABLE is it for managers to take the following actions?

(Please Circle the number that best describes your level of acceptance for each action.)

\begin{tabular}{|c|c|c|c|c|c|c|c|}
\hline Management Action & $\begin{array}{c}\text { Highly } \\
\text { Unacceptable }\end{array}$ & Unacceptable & $\begin{array}{c}\text { Somewhat } \\
\text { Unacceptable }\end{array}$ & $\begin{array}{c}\text { No } \\
\text { Opinion }\end{array}$ & $\begin{array}{l}\text { Somewhat } \\
\text { Acceptable }\end{array}$ & Acceptable & $\begin{array}{c}\text { Highly } \\
\text { Acceptable }\end{array}$ \\
\hline $\begin{array}{l}\text { Monitor the situation to } \\
\text { determine if the wolves } \\
\text { will cause further concern. }\end{array}$ & 1 & 2 & 3 & 4 & 5 & 6 & 7 \\
\hline $\begin{array}{l}\text { Frighten the wolves away } \\
\text { using non-lethal methods. }\end{array}$ & 1 & 2 & 3 & 4 & 5 & 6 & 7 \\
\hline $\begin{array}{l}\text { Capture and relocate the } \\
\text { wolves involved. }\end{array}$ & 1 & 2 & 3 & 4 & 5 & 6 & 7 \\
\hline $\begin{array}{l}\text { Move the remaining cattle } \\
\text { to another area of the } \\
\text { grazing allotment. }\end{array}$ & 1 & 2 & 3 & 4 & 5 & 6 & 7 \\
\hline $\begin{array}{l}\text { Remove the remaining } \\
\text { cattle in question from the } \\
\text { park. }\end{array}$ & 1 & 2 & 3 & 4 & 5 & 6 & 7 \\
\hline $\begin{array}{l}\text { Destroy the wolves } \\
\text { involved. }\end{array}$ & 1 & 2 & 3 & 4 & 5 & 6 & 7 \\
\hline
\end{tabular}




\section{SECTION II.}

In the previous section, you indicated how acceptable it was to take certain management actions following situations depicting conflicts between wolves and human activities or property. In this section, please indicate how EFFECTIVE you feel each of the management options listed below would be in remedying those conflicts.

(Please Circle the number that best describes how effective you believe each action would be.)

\begin{tabular}{|c|c|c|c|c|c|}
\hline $\begin{array}{l}\text { The Conflict } \\
\text { Management Actions }\end{array}$ & $\begin{array}{l}\text { Not at all } \\
\text { Effective }\end{array}$ & $\begin{array}{l}\text { Somewhat } \\
\text { Effective }\end{array}$ & Effective & $\begin{array}{l}\text { Extremely } \\
\text { Effective }\end{array}$ & $\begin{array}{l}\text { Don’t } \\
\text { Know }\end{array}$ \\
\hline \multicolumn{6}{|l|}{ To prevent wolves from entering an area on private property... } \\
\hline Frightening devices, such as loud sirens and flashing lights & 1 & 2 & 3 & 4 & DK \\
\hline Electric fences & 1 & 2 & 3 & 4 & DK \\
\hline Guard dogs & 1 & 2 & 3 & 4 & DK \\
\hline Shooting at wolves with non-lethal rubber bullets & 1 & 2 & 3 & 4 & DK \\
\hline \multicolumn{6}{|l|}{$\begin{array}{l}\text { To avoid human- wolf disturbances within Grand Teton National } \\
\text { Park... }\end{array}$} \\
\hline $\begin{array}{l}\text { Closure of sections of hiking trails that are close to wolf denning } \\
\text { areas. }\end{array}$ & 1 & 2 & 3 & 4 & DK \\
\hline Closure of entire hiking trails that pass near wolf denning areas. & 1 & 2 & 3 & 4 & DK \\
\hline \multicolumn{6}{|l|}{$\begin{array}{l}\text { To reduce future threat to human property following instances of } \\
\text { conflict between wolves and human activities or property... }\end{array}$} \\
\hline Capture and relocation of an entire pack involved. & 1 & 2 & 3 & 4 & DK \\
\hline Capture and relocation of an individual wolf involved. & 1 & 2 & 3 & 4 & DK \\
\hline Destroy an individual wolf that was in a pack involved. & 1 & 2 & 3 & 4 & DK \\
\hline Destroy the breeding pair of wolves in a pack involved. & 1 & 2 & 3 & 4 & DK \\
\hline Destroy the entire pack involved. & 1 & 2 & 3 & 4 & DK \\
\hline
\end{tabular}

\section{SECTION III.}

People feel a variety of emotions when encountering wild animals or hearing about conflicts between people and wild animals. Please indicate below how strongly you agree or disagree with each of the following statements about different feelings towards wolves.

(Please circle the appropriate number for each)

\begin{tabular}{|c|c|c|c|c|c|c|}
\hline & $\begin{array}{l}\text { Strongly } \\
\text { Disagree }\end{array}$ & Disagree & Neutral & Agree & $\begin{array}{l}\text { Strongly } \\
\text { Agree }\end{array}$ & $\begin{array}{l}\text { Don't } \\
\text { Know }\end{array}$ \\
\hline $\begin{array}{l}\text { - I get angry when I learn that a wolf has destroyed } \\
\text { someone's livestock. }\end{array}$ & 1 & 2 & 3 & 4 & 5 & DK \\
\hline $\begin{array}{l}\text { - It does not anger me to know that pet dogs may be } \\
\text { attacked and killed by wild animals, such as wolves. }\end{array}$ & 1 & 2 & 3 & 4 & 5 & DK \\
\hline $\begin{array}{l}\text { - I don't understand why some people become angry when } \\
\text { wolves destroy livestock. }\end{array}$ & 1 & 2 & 3 & 4 & 5 & DK \\
\hline $\begin{array}{l}\text { I don't think anyone should be afraid of wolves for any } \\
\text { reason. }\end{array}$ & 1 & 2 & 3 & 4 & 5 & DK \\
\hline $\begin{array}{l}\text { - I would never worry about my safety in an area that I } \\
\text { knew had wolves. }\end{array}$ & 1 & 2 & 3 & 4 & 5 & DK \\
\hline $\begin{array}{l}\text { - I have sympathy for wolves that rely on livestock for } \\
\text { food. }\end{array}$ & 1 & 2 & 3 & 4 & 5 & DK \\
\hline $\begin{array}{l}\text { - It angers me to learn that wolves may be destroyed if } \\
\text { they harass livestock but don't actually kill them. }\end{array}$ & 1 & 2 & 3 & 4 & 5 & DK \\
\hline
\end{tabular}




\begin{tabular}{|c|c|c|c|c|c|c|}
\hline & $\begin{array}{l}\text { Strongly } \\
\text { Disagree } \\
\end{array}$ & Disagree & Neutral & Agree & $\begin{array}{l}\text { Strongly } \\
\text { Agree }\end{array}$ & $\begin{array}{l}\text { Don't } \\
\text { Know } \\
\end{array}$ \\
\hline $\begin{array}{l}\text { - It saddens me to know that ranchers may suffer the loss of } \\
\text { their livestock due to wolf attacks. }\end{array}$ & 1 & 2 & 3 & 4 & 5 & DK \\
\hline $\begin{array}{l}\text { - I don't have any sympathy for wolves that are destroyed } \\
\text { for killing livestock. }\end{array}$ & 1 & 2 & 3 & 4 & 5 & DK \\
\hline $\begin{array}{l}\text { - It upsets me to learn that livestock has been destroyed by } \\
\text { re-introduced wolves. }\end{array}$ & 1 & 2 & 3 & 4 & 5 & DK \\
\hline $\begin{array}{l}\text { - I get angry with the National Park Service when I hear that } \\
\text { visitors in a national park may encounter wolves. }\end{array}$ & 1 & 2 & 3 & 4 & 5 & DK \\
\hline $\begin{array}{l}\text { - I have no sympathy for ranchers who lose livestock to } \\
\text { wolf attacks. }\end{array}$ & 1 & 2 & 3 & 4 & 5 & DK \\
\hline $\begin{array}{l}\text { I feel sorry for wolves when they are destroyed for any } \\
\text { reason. }\end{array}$ & 1 & 2 & 3 & 4 & 5 & DK \\
\hline $\begin{array}{l}\text { - I would never be fearful of a wolf if I saw one on my } \\
\text { property. }\end{array}$ & 1 & 2 & 3 & 4 & 5 & DK \\
\hline - It frightens me when I hear about wolves killing a pet dog & 1 & 2 & 3 & 4 & 5 & DK \\
\hline $\begin{array}{l}\text { It scares me knowing that wolves are living in Grand } \\
\text { Teton National Park. }\end{array}$ & 1 & 2 & 3 & 4 & 5 & DK \\
\hline - I understand why some people are fearful of wolves & 1 & 2 & 3 & 4 & 5 & DK \\
\hline
\end{tabular}

\section{SECTION IV.}

People have many different ideas about what is a tolerable number of encounters to have with wild animals. Please indicate if it would be a positive, negative or neutral EXPERIENCE if you had the following encounters with wolves.

(Please circle the appropriate number for each experience.)

\begin{tabular}{|c|c|c|c|c|c|c|c|c|}
\hline $\begin{array}{l}\text { What type of experience would this be } \\
\text { for you? }\end{array}$ & $\begin{array}{l}\text { Extremely } \\
\text { Positive }\end{array}$ & Positive & $\begin{array}{l}\text { Somewhat } \\
\text { Positive }\end{array}$ & Neutral & $\begin{array}{l}\text { Somewhat } \\
\text { Negative }\end{array}$ & Negative & $\begin{array}{l}\text { Extremely } \\
\text { Negative }\end{array}$ & $\begin{array}{l}\text { Don't } \\
\text { Know }\end{array}$ \\
\hline \multicolumn{9}{|l|}{$\begin{array}{l}\text { 1. You are camping at Grand Teton } \\
\text { National Park and have seen a wolf } \\
\text { near the campground where you are } \\
\text { staying ... }\end{array}$} \\
\hline once? & 1 & 2 & 3 & 4 & 5 & 6 & 7 & DK \\
\hline twice? & 1 & 2 & 3 & 4 & 5 & 6 & 7 & DK \\
\hline several times? & 1 & 2 & 3 & 4 & 5 & 6 & 7 & DK \\
\hline \multicolumn{9}{|l|}{$\begin{array}{l}\text { 2. You see a lone wolf traveling across } \\
\text { your own property... }\end{array}$} \\
\hline once a year? & 1 & 2 & 3 & 4 & 5 & 6 & 7 & DK \\
\hline once a month? & 1 & 2 & 3 & 4 & 5 & 6 & 7 & DK \\
\hline once a week? & 1 & 2 & 3 & 4 & 5 & 6 & 7 & DK \\
\hline daily? & 1 & 2 & 3 & 4 & 5 & 6 & 7 & DK \\
\hline \multicolumn{9}{|l|}{$\begin{array}{l}\text { 3. You are hiking at Grand Teton National } \\
\text { Park and see a pack of wolves in the } \\
\text { distance... }\end{array}$} \\
\hline on one hike? & 1 & 2 & 3 & 4 & 5 & 6 & 7 & DK \\
\hline on two separate hikes? & 1 & 2 & 3 & 4 & 5 & 6 & 7 & DK \\
\hline on several hikes? & 1 & 2 & 3 & 4 & 5 & 6 & 7 & DK \\
\hline
\end{tabular}




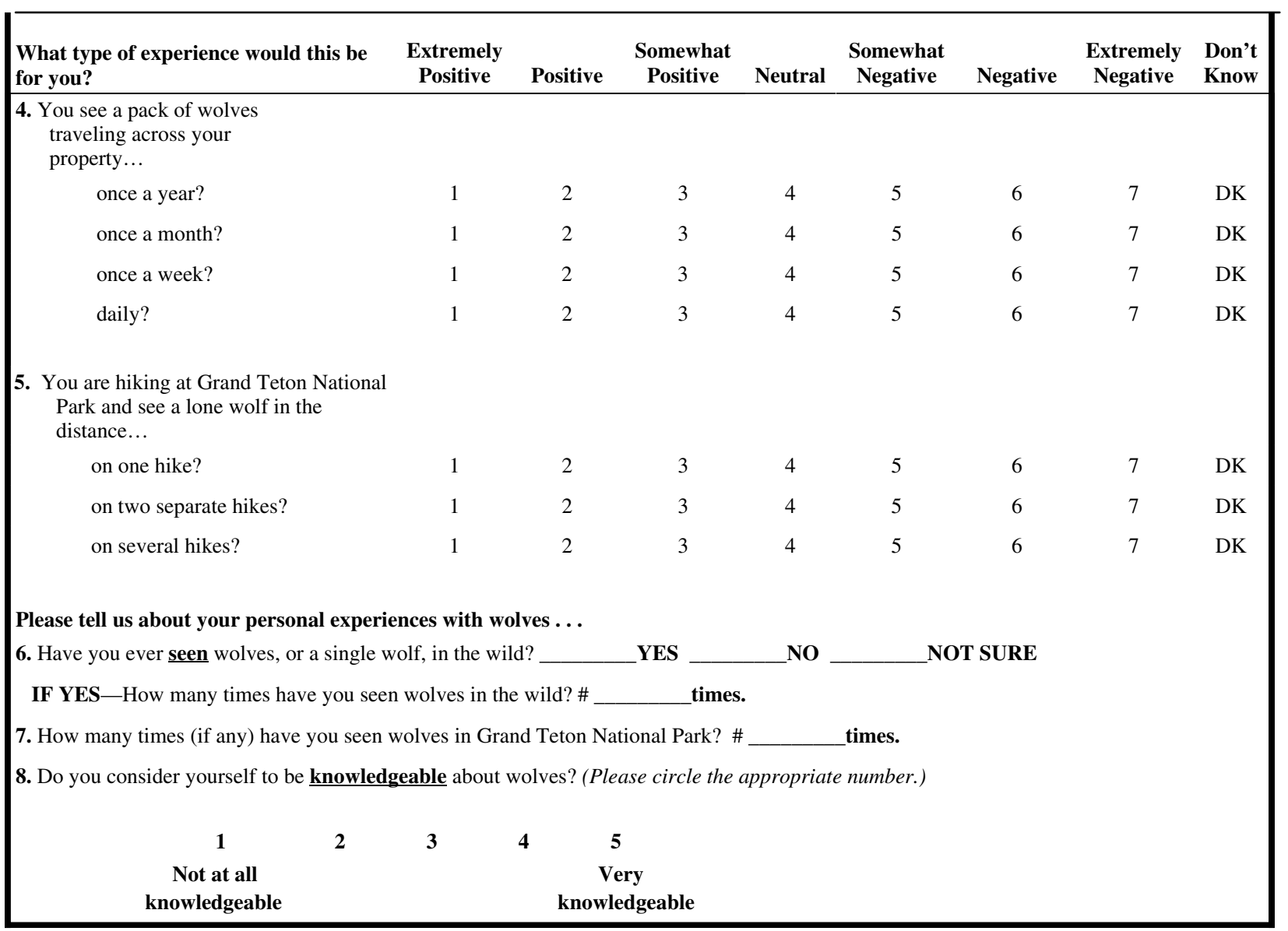

\section{SECTION V.}

Finally, we would like to ask you about your visit to Grand Teton National Park and your background. The information you supply will remain completely confidential.

1. Have you ever visited Grand Teton National Park? (If NO, please skip to question \#6) ___ Yes___No How long ago was your last visit to Grand Teton National Park? ___Days ___ Months ___ Years

2. During this visit to GRAND TETON NATIONAL PARK, what was the PRIMARY purpose of your trip? (What motivated you to visit Grand Teton Nat'l Park?) (Check the one most important purpose for this trip)

\begin{tabular}{lll}
$\begin{array}{l}\text { Camping } \\
\text { (developed campground) } \\
\text { Backcountry camping } \\
\text { (undeveloped campground) }\end{array}$ & _ Diew Scenery & Driving for pleasure \\
Hiking & $\ldots$ Ranger led activities/programs \\
Wildlife viewing & $\ldots$ Canoeing or boating (River) & Fishing \\
Photography & $\ldots$ Rock climbing & B Bicycling/Mountain biking \\
\hline
\end{tabular}


4. How long was your latest visit to Grand Teton National Park? (Check one only)

1 day visit only

2 day visit

3 day visit or more

5. If you were an overnight visitor in the SGYA, where did you stay? (check all that apply)

Camped in developed campground in the park

_L Lodge or hotel in the park

_ Camped in the backcountry of the park

Lodge or hotel outside of the park

_ Camped in developed campground outside of the park

_Stayed in own home

_Other, please describe

6. Are you?

Male

Female

7. How old are you?

Years

8. In what ethnic group (A) and race (B) would you put yourself?

A. Ethnicity (select one)

Hispanic or Latino

NOT Hispanic or Latino

B. Race (select one or more)

American Indian or Alaska native (if yes: please answer question 9) Asian

Black or African American

Native Hawaiian or other Pacific Islander

White

9. If you checked “American Indian”, please identify your tribal affiliation:

10. What is the highest level of education that you have achieved?

L Less than high school diploma

High school diploma or GED
Technical/vocational degree

Some college
4 year college degree

Advanced degree beyond 4-year degree

11. What is your approximate annual household income before taxes?

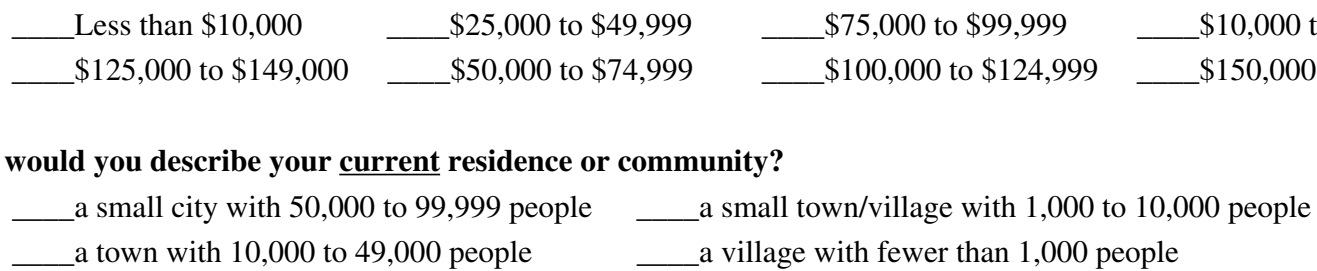

12. How would you describe your current residence or community?

a town with 10,000 to 49,000 people ___ _ _ a village with fewer than 1,000 people

a farm or rural area

Thank you for participating in this study. Your opinions are very valuable!

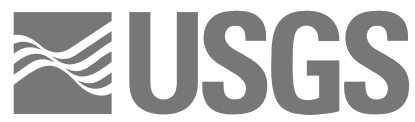




\section{Appendix D. Reliability Results for Emotion Indices}

To investigate emotions related to wolves and human-wolf encounters, four composite index variables were created based on sixteen emotion items. Reliability results for these composite variables indicated that the three items for 'sympathy for a rancher', the five items for 'anger about wolf presence', the five items for 'fear of wolves', and the three items for 'sympathy for wolves' were internally consistent with Cronbach's alpha values from 0.81 to 0.83 (Table D-1). These items worked consistently together to explain the larger composite variable (index), and removal of any one item would have reduced the explanatory power of the index.

Table D-1. Reliability analyses of emotion indices pertaining to human-wolf interactions. ${ }^{a}$

\begin{tabular}{|c|c|c|c|}
\hline Emotion items ${ }^{\mathrm{b}}$ & $\begin{array}{l}\text { Item total } \\
\text { correlation }\end{array}$ & $\begin{array}{l}\text { Alpha if item } \\
\text { deleted }^{d}\end{array}$ & $\begin{array}{l}\text { Cronbach's } \\
\text { alpha }^{e}\end{array}$ \\
\hline \multicolumn{4}{|l|}{ Sympathy for a rancher } \\
\hline $\begin{array}{l}\text { It saddens me to know that ranchers may suffer the loss of } \\
\text { their livestock due to wolf attacks. }\end{array}$ & .74 & .71 & .83 \\
\hline $\begin{array}{l}\text { It upsets me to learn that livestock has been destroyed by } \\
\text { reintroduced wolves. }\end{array}$ & .69 & .76 & \\
\hline $\begin{array}{l}\text { I have no sympathy for ranchers who lose livestock to wolf } \\
\text { attacks. }\end{array}$ & .63 & .81 & \\
\hline \multicolumn{4}{|l|}{ Anger about wolf presence } \\
\hline $\begin{array}{l}\text { I get angry when I learn that a wolf has destroyed someone's } \\
\text { livestock. }\end{array}$ & .76 & .73 & .82 \\
\hline $\begin{array}{l}\text { It does not anger me to know that pet dogs may be attacked } \\
\text { and killed by wild animals, such as wolves. }\end{array}$ & .63 & .78 & \\
\hline $\begin{array}{l}\text { I don't understand why some people become angry when } \\
\text { wolves destroy livestock. }\end{array}$ & .48 & .82 & \\
\hline It angers me to learn that wolves may be destroyed if they & & & \\
\hline harass livestock but don't actually kill them. ${ }^{f}{ }^{\prime}$ & .61 & .78 & \\
\hline $\begin{array}{l}\text { I get angry with the National Park Servcie when I hear that } \\
\text { visitors in a national park may encounter wolves. }\end{array}$ & .58 & .79 & \\
\hline \multicolumn{4}{|l|}{ Fear of wolves } \\
\hline $\begin{array}{l}\text { I don't think anyone should be afraid of wolves for any } \\
\text { reason. }\end{array}$ & .62 & .79 & .83 \\
\hline $\begin{array}{l}\text { I would never be fearful of a wolf if I saw one on my } \\
\text { property. }\end{array}$ & 67 & .78 & \\
\hline It frightens me when I hear about wolves killing a pet dog. & .56 & .81 & \\
\hline $\begin{array}{l}\text { It scares me knowing that wolves are living in Grand Teton } \\
\text { National Park. }\end{array}$ & .52 & .82 & \\
\hline I understand why some people are fearful of wolves. & .47 & .82 & \\
\hline $\begin{array}{l}\text { I would never worry about my safety in an area that in knew } \\
\text { had wolves. }\end{array}$ & .74 & .76 & \\
\hline \multicolumn{4}{|l|}{ Sympathy for wolves } \\
\hline $\begin{array}{l}\text { I have sympathy for wolves that rely on livestock for food. } \\
\text { I don't have any sympathy for wolves that are destroyed for }\end{array}$ & .62 & .78 & .81 \\
\hline killing livestock. ${ }^{\mathrm{f}} \mathrm{P}$ & .71 & .68 & \\
\hline I feel sorry for wolves when they are destroyed for any reason. & .65 & .75 & \\
\hline
\end{tabular}

a'Emotion items were coded on a 5-point Likert-type scale ranging from 1 'strongly disagree' to 5 'strongly agree'.

${ }^{b}$ Items with more than two missing values, for each respondent, were excluded from the creation of the index and received a missing value for that score on the index scale.

'Item total correlation is a diagnostic used in conjunction with Cronbach's alpha to determine scale internal consistency, values over .40 indicate good internal consistency (Nunnally, 1978) 
dAlpha if item deleted is a diagnostic used in conjunction with Cronbach's alpha to assist in scale formation. Values higher than Cronbach's alpha indicate an item may need to be removed from the scale (Nunnally, 1978).

${ }^{\mathrm{e}} \mathrm{Cronbach}$ 's alpha measures the internal consistency of the emotion indices. It is a reliability coefficient based on the average correlation of any one item with all other items that are to be included in the composite index. An alpha coefficient of $\geq 0.60$ indicates a reliable scale (Nunnally, 1978).

${ }^{\mathrm{f}}$ Items were reverse coded. 


\section{Appendix E. Relationship between Judgments of Responsibility and Acceptance of Management Actions}

We proposed the following interactions between responsibility judgements and acceptability of management actions: If a person places primary responsibility with the individual (Hiker, Rancher, Pet Owner), then he would be more willing to accept management that directly affected the individual. Conversely, if a person thinks responsibility resides primarily with a wildlife management agency, then her acceptance of actions impacting the wolves, through the agency, would be greater. From this, we proposed these three hypotheses:

Hypothesis 1: The more a person places responsibility on the individual (i.e., hikers, ranchers, and pet owners), the less likely that person is to accept management actions that are invasive to wolves.

Hypothesis 2: The more responsibility a person places on an agency, the more likely that person will accept management actions that are invasive to wolves.

Hypothesis 3: The more responsibility a person places on the individual, the more likely that person is to accept management actions that impact the individual.

\section{Scenarios Involving Hiking Encounters in Grand Teton National Park (Scenarios One and Five; Tables E-1 and E-2)}

For scenarios involving hiker-wolf conflicts, the results generally supported the hypothesized relationships, with the exception of GRTE relationships (Tables E-1 \& E-2). For these scenarios, the more responsibility placed on the hiker, the less likely management actions invasive to wolves were acceptable (Hypothesis 1). On the other hand, those assigning more responsibility to the wildlife agencies, WYG\&F and USFWS, were more likely to accept management actions that are invasive to wolves (Hypothesis 2). In the case of the WYG\&F, the comparisons show "minimal" or less than minimal relationships. For the USFWS, positive, statistically significant correlations were with 'capture and relocate the wolves involved' (Scenario 1, $r=.30$; Scenario 5, $r=.24$ ). The correlations between GRTE and invasive management action acceptability did not fully support Hypothesis 2 . The relationships were positive for Scenario 1 ( $r=.11$, Table E-1), however for Scenario 5, the relationships were negative ( $r=-.03$ and -.07 , Table E-2). Hypothesis 3 was supported, although it is interesting to note that the correlations were higher for 'monitor the situation' than for the management actions that impact the hiker. 
Table E-1. Correlations of proportional judgments of responsibility with acceptance of management actions for scenario one. ${ }^{\mathrm{a}}$

\begin{tabular}{|c|c|c|c|c|}
\hline \multirow[b]{2}{*}{ Acceptability of management action ${ }^{c}$} & \multicolumn{4}{|c|}{ Judgments of responsibility ${ }^{\mathrm{b}}$} \\
\hline & Hiker & $\begin{array}{c}\text { Grand Teton } \\
\text { National Park }\end{array}$ & $\begin{array}{l}\text { Wyoming } \\
\text { Game \& Fish }\end{array}$ & $\begin{array}{c}\text { U.S. Fish \& } \\
\text { Wildlife Service }\end{array}$ \\
\hline Monitor the situation & $.31 * *$ & .04 & $-.07 *$ & $-.33 * *$ \\
\hline Frighten the wolves away & $-.09 * *$ & $.11 * *$ & $.12 * *$ & .02 \\
\hline Capture and relocate the wolves involved & $-.38 * *$ & $.11^{* *}$ & $.29 * *$ & $.30^{* *}$ \\
\hline $\begin{array}{l}\text { Close only the section of the trail that the } \\
\text { wolves are near }\end{array}$ & $.28 * *$ & $.08 * *$ & $-.11 * *$ & $-.32 * *$ \\
\hline $\begin{array}{l}\text { Close the entire trail until the wolves have left } \\
\text { the area }\end{array}$ & $.15^{* *}$ & $.07 *$ & -.03 & -.19 \\
\hline
\end{tabular}

${ }^{a}$ Scenario 1 (Location: On a popular backcountry hiking trail in GRTE, Encounter: A hiker sees several wolves feeding on a dead deer close to the trail. The wolves seem reluctant to leave their kill, Status of the wolves: Listed as an endangered species, experimental population.)

${ }^{b}$ Respondents assigned proportions of responsibility, as a percentage, to each of the four choices listed. Cell entries represent bi-variate correlations. $* p<.05 * * p<.01$.

'Acceptance of management action coded on a 7-point Likert-type scale ranging from $1=$ 'highly unacceptable' to $7=$ 'highly acceptable'.

Table E-2. Correlations of proportional judgments of responsibility with acceptance of management actions for scenario five. ${ }^{a}$

\begin{tabular}{|c|c|c|c|c|}
\hline \multirow[b]{2}{*}{ Acceptability of management action ${ }^{c}$} & \multicolumn{4}{|c|}{ Judgments of responsibility $^{b}$} \\
\hline & Hiker & $\begin{array}{l}\text { Grand Teton } \\
\text { National Park }\end{array}$ & $\begin{array}{l}\text { Wyoming } \\
\text { Game \& Fish }\end{array}$ & $\begin{array}{c}\text { U.S. Fish \& } \\
\text { Wildlife Service }\end{array}$ \\
\hline Monitor the situation & $.26^{* *}$ & $.09 * *$ & $-.10 * *$ & $-.32 * *$ \\
\hline Frighten the wolves away & -.03 & -.03 & $.12 * *$ & .02 \\
\hline Capture and relocate the wolves involved & $-.22 * *$ & $-.07 *$ & $.22 * *$ & $.24 * *$ \\
\hline $\begin{array}{l}\text { Close only the section of the trail that the } \\
\text { wolves are near }\end{array}$ & $.22 * *$ & $.15^{* *}$ & $-.10 * *$ & $-33 * *$ \\
\hline $\begin{array}{l}\text { Close the entire trail until the wolves have left } \\
\text { the area }\end{array}$ & $.11 * *$ & $.12 * *$ & -.03 & $-.21 * *$ \\
\hline
\end{tabular}

${ }^{a}$ Scenario 5 (Location: On a popular backcountry hiking trail in GRTE, Encounter: A hiker sees several wolves and their pups near what appears to be a denning site. As the hiker watches, the wolves become aware of the hiker's presence, Status of the wolves: Wolf numbers have increased; they are no longer listed as an endangered species.)

${ }^{\mathrm{b}}$ Respondents assigned proportions of responsibility, as a percentage, to each of the four choices listed. Cell entries represent bi-variate correlations. $* p<.05 * * p<.01$.

'Acceptance of management action coded on a 7-point Likert-type scale ranging from 1 = 'highly unacceptable' to 7 = 'highly acceptable'. 


\section{Scenarios Involving Rancher-Wolf Conflicts (Scenarios Two, Three, and Six; Tables E-3, $\mathrm{E}-4$, and E-5)}

For scenarios involving rancher-wolf conflicts, the hypothesized relationships between the judgments of responsibility and acceptance of management actions were supported for Hypothesis 1 with the exception of 'frighten the wolves away'. Thus, as more responsibility was placed on the rancher, the less likely management actions invasive to wolves were supported such as capturing or destroying the wolves. However; frightening the wolves away was viewed differently, possibly as less invasive. When considering agency responsibility and acceptance of management actions (Hypothesis 2), the hypothesized relationships were generally supported statistically for WYG\&F and USFWS. 'Frighten the wolves away' is again an exception (for USFWS, $r=-.06$ to -.22 ; for WYG\&F $r=.002$ to .05 , none significant). Also, the relationships for GRTE did not consistently support the hypothesized relationships since 'destroy the wolves' had negative correlations in all three scenarios ( $r=-.05$ to -.14). However, GRTE correlations are low (minimal to less than minimal for all relationships). Hypothesis 3 was applicable in Scenarios 2 and 6 but not Scenario 3 in which no 'invasive to the rancher' (e.g., move or remove the cattle) was offered on the rancher's own property. Not only was the hypothesized relationship supported (as more responsibility is placed on the rancher, the more likely management actions that impact the rancher will be acceptable), but also the correlations were of typical $(r \geq .3)$ to substantial $(r \geq .5)$ strength.

Table E-3. Correlations of proportional judgments of responsibility with acceptance of management actions for scenario two. ${ }^{a}$

\begin{tabular}{lcccc}
\hline & \multicolumn{4}{c}{ Judgments of responsibility $^{\mathrm{b}}$} \\
\cline { 2 - 5 } Acceptability of management action $^{\mathrm{c}}$ & Rancher & $\begin{array}{c}\text { Grand Teton } \\
\text { National Park }\end{array}$ & $\begin{array}{c}\text { Wyoming } \\
\text { Game \& Fish }\end{array}$ & $\begin{array}{c}\text { U.S. Fish and } \\
\text { Wildlife Service }\end{array}$ \\
\hline Monitor the situation & $.29^{* *}$ & $.12^{* *}$ & -.05 & $-.30^{* *}$ \\
Frighten the wolves away & -.03 & $.19^{* *}$ & .04 & $-.06^{*}$ \\
$\begin{array}{l}\text { Capture and relocate the wolves involved } \\
\text { Move the cattle to another area of the }\end{array}$ & $-.37^{* *}$ & $.12^{* *}$ & $.21^{* *}$ & $.24^{* *}$ \\
grazing allotment & $.48^{* *}$ & .04 & $-.16^{* *}$ & $-.42^{* *}$ \\
$\begin{array}{l}\text { Remove the cattle from the park } \\
\text { Destroy the wolves involved }\end{array}$ & $.50^{* *}$ & -.04 & $-.17^{* *}$ & $-.39^{* *}$ \\
\hline
\end{tabular}

acenario 2 (Location: Federal grazing allotment in GRTE, Encounter: A pack of wolves has been chasing cattle from a small herd from time to time over the past 2 weeks. The wolves have not killed any cattle, Status of the wolves: Listed as an endangered species, experimental population.)

${ }^{b}$ Respondents assigned proportions of responsibility, as a percentage, to each of the four choices listed. Cell entries represent bi-variate correlations. $* p<.05 * * p<.01$.

'Acceptance of management action coded on a 7-point Likert-type scale ranging from $1=$ 'highly unacceptable' to $7=$ 'highly acceptable'. 
Table E-4. Correlations of proportional judgments of responsibility with acceptance of management actions for scenario three. ${ }^{a}$

\begin{tabular}{lcccc}
\hline & \multicolumn{4}{c}{ Judgments of responsibility } \\
\cline { 2 - 5 } Acceptability of management action $^{\mathrm{c}}$ & Rancher & $\begin{array}{c}\text { Grand Teton } \\
\text { National Park }\end{array}$ & $\begin{array}{c}\text { Wyoming } \\
\text { Game \& Fish }\end{array}$ & $\begin{array}{c}\text { U.S. Fish \& } \\
\text { Wildlife Service }\end{array}$ \\
\hline Monitor the situation & $.28^{* *}$ & $.09^{* *}$ & -.02 & $-.27^{* *}$ \\
Frighten the wolves away & $.17^{* *}$ & $.11^{* *}$ & .05 & $-.19^{* *}$ \\
Capture and relocate the wolves involved & $-.09^{* *}$ & $.13^{* *}$ & $.12^{* *}$ & -.03 \\
Destroy the wolves involved & $-.35^{* *}$ & $-.09^{* *}$ & -.02 & $.35^{* *}$ \\
\hline
\end{tabular}

acenario 3 (Location: On private ranch land next to GRTE, Encounter: A local rancher in the Jackson-Hole area has reported the loss of several cattle within the last month due to wolf kills, Status of the wolves: Listed as an endangered species, experimental population.)

${ }^{\mathrm{b}}$ Respondents assigned proportions of responsibility, as a percentage, to each of the four choices listed. Cell entries represent bi-variate correlations. $* * p<.01$.

'Acceptance of management action coded on a 7-point Likert-type scale ranging from $1=$ 'highly unacceptable' to $7=$ 'highly acceptable'.

Table E-5. Correlations of proportional judgments of responsibility with acceptance of management actions for scenario six. ${ }^{a}$

\begin{tabular}{lcccc}
\hline & \multicolumn{4}{c}{ Judgments of responsibility $^{\mathrm{b}}$} \\
\cline { 2 - 5 } Acceptability of management action $^{\mathrm{c}}$ & Rancher & $\begin{array}{c}\text { Grand Teton } \\
\text { National Park }\end{array}$ & $\begin{array}{c}\text { Wyoming } \\
\text { Game \& Fish }\end{array}$ & $\begin{array}{c}\text { U.S. Fish \& } \\
\text { Wildlife Service }\end{array}$ \\
\hline Monitor the situation & $.33^{* *}$ & .02 & -.05 & $-.32^{* *}$ \\
Frighten the wolves away & $.12^{* *}$ & $.16^{* *}$ & .002 & $-.22^{* *}$ \\
Capture and relocate the wolves involved & $-.17^{* *}$ & $.21^{* *}$ & $.09 * *$ & .02 \\
$\begin{array}{l}\text { Move the cattle to another area of the grazing } \\
\text { allotment }\end{array}$ & $.41^{* *}$ & .05 & $-.11^{* *}$ & $-.39 * *$ \\
Remove the cattle from the park & $.48^{* *}$ & -.02 & $.15^{* *}$ & $-.39^{* *}$ \\
Destroy the wolves involved & $-.46^{* *}$ & -.05 & $.17^{* *}$ & $.42^{* *}$ \\
\hline
\end{tabular}

${ }^{\text {a Scenario } 6}$ (Location: Federal grazing allotment in GRTE, Encounter: A cattle rancher has reported the loss of several cattle within the last month, killed by wolves, Status of the wolves: Wolf numbers have increased; they are no longer listed as an endangered species.)

${ }^{b}$ Respondents assigned proportions of responsibility, as a percentage, to each of the four choices listed. Cell entries represent bi-variate correlations. $* * p<.01$.

'Acceptance of management action coded on a 7-point Likert-type scale ranging from 1 = 'highly unacceptable' to $7=$ 'highly acceptable'. 


\section{Scenario Involving Pet Loss (Scenario Four; Table E-6)}

For the scenario depicting pet loss, Hypotheses 1 and 2 were supported with the exception of 'frighten the wolves away' where Homeowner and USFWS responded contrary to the hypothesized relationships. When an agency was held responsible, management actions invasive to wolves generally were supported: for GRTE and WYG\&F, 'capture and relocate'; for USFWS 'destroy the wolves' (Hypothesis 2). Hypothesis 3 was supported in this pet-loss situation as it was in the wolf-cattle encounter scenarios.

Table E-6. Correlations of proportional judgments of responsibility with acceptance of management actions for scenario four. ${ }^{\text {a }}$

\begin{tabular}{lcccc}
\hline & \multicolumn{4}{c}{ Judgments of responsibility $^{\mathrm{b}}$} \\
\cline { 2 - 5 } Acceptability of management action $^{\mathrm{c}}$ & Homeowner & $\begin{array}{c}\text { Grand Teton } \\
\text { National Park }\end{array}$ & $\begin{array}{c}\text { Wyoming } \\
\text { Game \& Fish }\end{array}$ & $\begin{array}{c}\text { U.S. Fish \& } \\
\text { Wildlife }\end{array}$ \\
\hline Monitor the situation & $.31^{* *}$ & .01 & -.001 & $-.31^{* *}$ \\
Frighten the wolves away & $.25^{* *}$ & .06 & .06 & $-.31^{* *}$ \\
Capture and relocate the wolves involved & $-.07^{*}$ & $.11^{* *}$ & $.15^{* *}$ & $-.06^{*}$ \\
Destroy the wolves involved & $-.39^{* *}$ & .01 & $.08^{* *}$ & $.36^{* *}$ \\
\hline
\end{tabular}

${ }^{a}$ Scenario 4 (Location: On private land next to GRTE, Encounter: A homeowner has recently had their pet dog killed by a wolf. Status of the wolves: Wolf numbers have increased; they are no longer listed as an endangered species.)

${ }^{\mathrm{b}}$ Respondents assigned proportions of responsibility, as a percentage, to each of the four choices listed. Cell entries represent bi-variate correlations. $* p<.05 * * p<.01$.

'Acceptance of management action coded on a 7-point Likert-type scale ranging from $1=$ 'highly unacceptable' to $7=$ 'highly acceptable'. 


\section{Appendix F. Relationship between Judgments of Responsibility and Emotion Indices}

It was reasoned that emotions about wolves and affected human activities would be related to judgments of responsibility as well as to perceived accptability of different management alternatives. In the first instance, as a person assigned greater responsibility to the individual involved in a wolf conflict situation, they would feel less sympathy for that individual, and more sympathy toward the wolves. Likewise, assigning responsibility to the person involved might reflect less anger felt about the presence of wolves. On the other hand, persons who assigned more responsibility to an agency, especially a wildlife agency, would likely feel more sympathy for the rancher or other individuals involved and more anger and fear about the presence of wolves in the area. This reasoning led to the following two hypotheses:

Hypothesis 4: The more responsibility a person places on the individual involved (i.e., hiker, rancher, or pet owner) in a human-wolf conflict, the lower that person's anger and fear will be toward wolves, and the greater their sympathy toward wolves.

Hypothesis 5: The more responsibility a respondent places on a management agency, the greater the anger and fear will be toward wolves, the lower the sympathy will be toward wolves, and the greater the sympathy for the person involved (i.e., hiker, rancher, or pet owner).

\section{Scenarios Involving Hiking Encounters in Grand Teton National Park (Scenarios One and Five; Tables F-1 and F-2)}

For the scenarios involving hikers encountering wolves within the park, the hypothesized relationships were supported for all but one of the relationships among the three variables in the model (Tables F-1 \& F-2). For these scenarios, those assigning more responsibility to the hikers felt sympathy for the wolves and significantly less anger or fear about wolves, in all comparisons at or near "typical relationship" levels. Conversely, those who held the wildlife agencies more responsible felt more anger and fear toward wolves and significantly less sympathy toward them (Hypothesis 5). In the case of the USFWS, these comparisons were at or near "typical relationship" levels. For the WYG\&F, these comparisons are statistically significant but were at the level of "minimal relationship," in part because of the low level of responsibility assigned to the state agency overall.

The correlations between GRTE as the responsible party and the emotions of fear $(r=-$ $.03)$ and anger $(r=-.09)$ felt towards the presence of wolves for Scenario 5 were in a negative direction (Table F-2), while sympathy for wolves was positively correlated. For Scenario 1, the pattern of relationship is mixed: positively correlated with anger but negatively correlated with fear of wolves. Thus Hypothesis 5 is not supported for GRTE. It should also be noted that all correlations between GRTE and the emotion indices were small (less than minimal effects) in both scenarios. This suggests some ambiguity in the minds of the public as to the wildlife management role the park may play. 
Table F-1. Correlations of three emotion indices with proportional judgments of responsibility for scenario one. ${ }^{a}$

\begin{tabular}{lccc}
\hline & \multicolumn{3}{c}{ Emotion indices $^{\mathrm{b}}$} \\
\cline { 2 - 4 } Judgment of responsibility $^{\mathrm{c}}$ & $\begin{array}{c}\text { Anger felt about } \\
\text { wolf presence }\end{array}$ & $\begin{array}{c}\text { Sympathy for } \\
\text { wolves }\end{array}$ & $\begin{array}{c}\text { Fear of } \\
\text { wolves }\end{array}$ \\
\hline Hiker & $-.48^{* *}$ & $.39^{* *}$ & $-.34^{* *}$ \\
Grand Teton National Park & $.07^{*}$ & -.03 & $-.09^{* *}$ \\
Wyoming Game \& Fish & $.27^{* *}$ & $-.18^{* *}$ & $.20^{* *}$ \\
U.S. Fish and Wildlife Service & $.44 * *$ & $-.38^{* *}$ & $.27^{* *}$ \\
\hline
\end{tabular}

acenario 1 (Location: On a popular backcountry hiking trail in GRTE, Encounter: A hiker sees several wolves feeding on a dead deer close to the trail. The wolves seem reluctant to leave their kill, Status of the wolves: Listed as an endangered species, experimental population.)

${ }^{\mathrm{b}}$ Indices are comprised of various emotion items coded on a 5-point Likert-type scale ranging from 1 'strongly disagree' to 5 'strongly agree'. Cell entries represent bi-variate correlations: $* p<.05 * * p<.01$.

${ }^{c}$ Respondents assigned proportions of responsibility, as a percentage, to each of the four choices listed.

Table F-2. Correlations of three emotion indices with proportional judgments of responsibility for scenario five. ${ }^{a}$

\begin{tabular}{lccc}
\hline & \multicolumn{3}{c}{ Emotion indices $^{\mathrm{b}}$} \\
\cline { 2 - 4 } Judgment of responsibility $^{\mathrm{c}}$ & $\begin{array}{c}\text { Anger felt about } \\
\text { wolf presence }\end{array}$ & $\begin{array}{c}\text { Sympathy } \\
\text { for wolves }\end{array}$ & $\begin{array}{c}\text { Fear of } \\
\text { wolves }\end{array}$ \\
\hline Hiker & $-.37^{* *}$ & $.28^{* *}$ & $-.29^{* *}$ \\
Grand Teton National Park & $-.09^{* *}$ & $.09^{* *}$ & -.03 \\
Wyoming Game \& Fish & $.23^{* *}$ & $-.13^{* *}$ & $.18^{* *}$ \\
U.S. Fish and Wildlife & $.41^{* *}$ & $-.35^{* *}$ & $.27^{* *}$ \\
\hline
\end{tabular}

${ }^{a}$ Scenario 5 (Location: On a popular backcountry hiking trail in GRTE, Encounter: A hiker sees several wolves and their pups near what appears to be a denning site. As the hiker watches, the wolves become aware of the hiker's presence, Status of the wolves: Wolf numbers have increased; they are no longer listed as an endangered species.)

${ }^{\mathrm{b}}$ Indices are comprised of various emotion items coded on a 5-point Likert-type scale ranging from 1 'strongly disagree' to 5 'strongly agree'. Cell entries represent bivariate correlations: $* * p<.01$.

${ }^{c}$ Respondents assigned proportions of responsibility, as a percentage, to each of the four choices listed.

\section{Scenarios Involving Rancher-Wolf Conflicts (Scenarios Two, Three, and Six; Tables F-3, 21, and F-5)}

For scenarios involving rancher-wolf conflicts, the hypothesized relationships between the judgments of responsibility and the emotion indices were supported for Hypothesis 4. In other words, responsibility for the rancher was positively related to sympathy for wolves and negatively correlated with anger and fear of wolves. In the scenarios involving grazing allotments within the park (Scenarios $2 \&$ 6, Tables F-3 \& F-5), the negative correlations between "rancher responsibility" and sympathy for the rancher and anger about wolf presence are at the "substantially" negative level and other correlations are at or near the typical level. All of these correlations are about 10\% stronger for in-park grazing allotments than for the private land rancher scenario. 
Again, wildlife agency responsibility shows a reverse pattern to rancher responsibility, particularly for the in-park scenarios. Note that for Scenarios $2 \& 6$, sympathy for rancher and anger about wolf presence correlate, positively, about $10 \%$ more strongly - at typical relationship levels - than for the off-park Scenario 3 (Table F-4 vs. F-3 \& F-5). Fear of wolves shows the same pattern, but at a lower overall correlation level. Although the USFWS is held to be significantly more responsible for the off-park scenario (37\% compared to 27-28\% - see Figures 3, 4, \& 7), the emotional relationship is much stronger for in-park grazing allotments. Again, the WYG\&F responsibility and emotions correlations are much lower (minimal relationships) than for the USFWS, but maintain the predicted pattern for the in-park scenarios (Tables F-3 \& F-5). For the off-park Scenario 3, Hypothesis 5 does not hold for the WYG\&F, where the correlations are below minimal significance for sympathy for or fear of wolves.

Table F-3. Correlations of four emotion indices with proportional judgments of responsibility for scenario two. ${ }^{a}$

\begin{tabular}{lcccc}
\hline & \multicolumn{4}{c}{ Emotion indices $^{\mathrm{b}}$} \\
\cline { 2 - 5 } Judgment of responsibility $^{\mathrm{c}}$ & $\begin{array}{c}\text { Sympathy for } \\
\text { rancher }\end{array}$ & $\begin{array}{c}\text { Anger felt about } \\
\text { wolf presence }\end{array}$ & $\begin{array}{c}\text { Sympathy } \\
\text { for wolves }\end{array}$ & $\begin{array}{c}\text { Fear of } \\
\text { wolves }\end{array}$ \\
\hline Rancher & $-.49 * *$ & $-.52^{* *}$ & $.41^{* *}$ & $-.28^{* *}$ \\
Grand Teton National Park & .05 & .01 & .04 & -.01 \\
Wyoming Game \& Fish & $.21^{* *}$ & $.20^{* *}$ & $-.12^{* *}$ & $.14 * *$ \\
U.S. Fish \& Wildlife Service & $.35 * *$ & $.42^{* *}$ & $-.37 * *$ & $.21^{* *}$ \\
\hline
\end{tabular}

acenario 2 (Location: Federal grazing allotment in GRTE, Encounter: A pack of wolves has been chasing cattle from a small herd from time to time over the past 2 weeks. The wolves have not killed any cattle, Status of the wolves: Listed as an endangered species, experimental population.)

${ }^{\mathrm{b}}$ Indices are comprised of various emotion items coded on a 5-point Likert-type scale ranging from 1 'strongly disagree' to 5 'strongly agree'. Cell entries represent bi-variate correlations: $* * p<.01$.

${ }^{c}$ Respondents assigned proportions of responsibility, as a percentage, to each of the four choices listed.

As in the hiker-wolf conflict scenarios, the correlations between GRTE and the emotion indices were small (less than minimal effects), and most were not statistically significant. This is true for the in-park scenarios as well as the off-park rancher scenario. However, the relationships in Hypothesis 5 were supported for all statistically significant correlations in rancher-wolf conflict scenarios. 
Table F-4. Correlations of four emotion indices with proportional judgments of responsibility for scenario three. ${ }^{a}$

\begin{tabular}{lcccc}
\hline & \multicolumn{4}{c}{ Emotion indices $^{\mathrm{b}}$} \\
\cline { 2 - 5 } & $\begin{array}{c}\text { Sympathy for } \\
\text { rancher }\end{array}$ & $\begin{array}{c}\text { Anger felt about } \\
\text { wolf presence }\end{array}$ & $\begin{array}{c}\text { Sympathy } \\
\text { for wolves }\end{array}$ & $\begin{array}{c}\text { Fear of } \\
\text { wolves }\end{array}$ \\
\hline Ranchen & $-.39 * *$ & $-.39^{* *}$ & $.31^{* *}$ & -.22 \\
Grand Teton National Park & .03 & .02 & $.07 *$ & .03 \\
Wyoming Game \& Fish & $.10^{* *}$ & $.06^{*}$ & .001 & .05 \\
U.S. Fish \& Wildlife Service & $.25 * *$ & $.28^{* *}$ & $-.30^{* *}$ & $.12 * *$ \\
\hline
\end{tabular}

acenario 3 (Location: On private ranch land next to GRTE, Encounter: A local rancher in the Jackson-Hole area has reported the loss of several cattle within the last month due to wolf kills, Status of the wolves: Listed as an endangered species, experimental population.)

${ }^{\mathrm{b}}$ Indices are comprised of various emotion items coded on a 5-point Likert scale ranging from 1 'strongly disagree' to 5 'strongly agree'. Cell entries represent bi-variate correlations: $* p<.05 * * p<.01$.

${ }^{c}$ Respondents assigned proportions of responsibility, as a percentage, to each of the four choices listed.

Table F-5. Correlations of four emotion indices with proportional judgments of responsibility for scenario six. ${ }^{a}$

\begin{tabular}{lcccc}
\hline & \multicolumn{4}{c}{ Emotion indices $^{\mathrm{b}}$} \\
\cline { 2 - 5 } & $\begin{array}{c}\text { Sympathy for } \\
\text { rancher }\end{array}$ & $\begin{array}{c}\text { Anger felt about } \\
\text { wolf presence }\end{array}$ & $\begin{array}{c}\text { Sympathy } \\
\text { for wolves }\end{array}$ & $\begin{array}{c}\text { Fear of } \\
\text { wolves }\end{array}$ \\
\hline Rudgment of responsibility & $-.50^{* *}$ & $-.50^{* *}$ & $.38^{* *}$ & $-.32^{* *}$ \\
Gancher & $.09^{* *}$ & .03 & .04 & .02 \\
Wyoming Teton National Park & $.17^{* *}$ & $.18^{* *}$ & $-.13^{* *}$ & $.13^{* *}$ \\
U.S. Fish \& Wildlife Service & $.35^{* *}$ & $.39 * *$ & $-.34^{* *}$ & $.22^{* *}$ \\
\hline
\end{tabular}

${ }^{\text {a Scenario } 6}$ (Location: Federal grazing allotment in GRTE, Encounter: A cattle rancher has reported the loss of several cattle within the last month, killed by wolves, Status of the wolves: Wolf numbers have increased; they are no longer listed as an endangered species.)

${ }^{\mathrm{b}}$ Indices are comprised of various emotion items coded on a 5-point Likert-type scale ranging from 1 'strongly disagree' to 5 'strongly agree'. Cell entries represent bi-variate correlations: $* * p<.01$.

${ }^{c}$ Respondents assigned proportions of responsibility, as a percentage, to each of the four choices listed. 


\section{Scenario Involving Pet Loss (Scenario Four; Table F-6)}

For the scenario depicting pet loss due to a wolf attack (Scenario 4, Table F-6), the statistically significant correlations are in the predicted direction between responsible parties and emotion items for Hypothesis $4 \& 2$. However, the sympathy for wolves index and two management agencies (GRTE and WYG\&F) yielded less than minimal correlations and were not statistically significant.

Table F-6. Correlations of three emotion indices with proportional judgments of responsibility for scenario four. ${ }^{\text {a }}$

\begin{tabular}{lccc}
\hline & \multicolumn{3}{c}{ Emotion indices $^{\mathrm{b}}$} \\
Judgment of responsibility $^{\mathrm{c}}$ & $\begin{array}{c}\text { Anger felt about } \\
\text { wolf presence }\end{array}$ & $\begin{array}{c}\text { Sympathy for } \\
\text { wolves }\end{array}$ & $\begin{array}{c}\text { Fear of } \\
\text { wolves }\end{array}$ \\
\hline Pet-owner & $-.44^{* *}$ & $.32^{* *}$ & $-.36^{* *}$ \\
Grand Teton National Park & $.08^{* *}$ & .00 & $.11^{* *}$ \\
Wyoming Game \& Fish & $.08^{* *}$ & -.03 & $.10^{* *}$ \\
U.S. Fish \& Wildlife Service & $.37^{* *}$ & $-.33^{* *}$ & $.24^{* *}$ \\
\hline
\end{tabular}

a Scenario 4 (Location: On private land next to GRTE, Encounter: A homeowner has recently had their pet dog killed by a wolf. Status of the wolves: Wolf numbers have increased; they are no longer listed as an endangered species.)

'Indices are comprised of various emotion items coded on a 5-point Likert scale ranging from 1 'strongly disagree' to 5 'strongly agree'. Cell entries represent bi-variate correlations: $* p<.01$.

${ }^{c}$ Respondents assigned proportions of responsibility, as a percentage, to each of the four choices listed.

Overall, in all six scenarios Hypothesis 4 was supported. Responsibility placed on the individual involved (i.e., the hiker, rancher, or pet owner) was related to less anger and fear towards wolves and more sympathy towards wolves. For Hypothesis 5, the results for all significant correlations were in the predicted directions, especially for the USFWS. However, judgments of responsibility for GRTE tended to yield non-significant correlations with the emotion indices, and the WYG\&F yielded at best minimal correlations. 


\section{Appendix G. Relationship between Emotion Indices and Acceptance of Management Actions}

It is hypothesized that emotions felt about a human-wolf encounter will correlate with the acceptability of different management actions taken to remedy or avoid the situation. This expected interrelationship is defined in the following hypotheses:

Hypothesis 6: The more sympathy a person feels towards wolves, the less likely that person will accept management actions that are invasive to wolves and the more likely to accept management actions that impact the individual involved.

Hypothesis 7: The more fear or anger held towards wolves, the more likely that person will accept management actions that are invasive to wolves and the less likely to accept management actions that impact the individual involved.

Hypothesis 8: The more sympathy a person holds for the individual involved in a conflict, the more likely that person will accept management actions that are invasive to wolves and the less likely to accept management actions that impact the individual. 


\section{Scenarios Involving Hiking Encounters in Grand Teton National Park (Scenarios One and Five; Tables G-1 and G-2)}

For the scenarios involving hikers encountering wolves within the park, Hypotheses 3 and 4 were supported (Hypothesis 8 was not tested for hikers). As sympathy towards wolves increased the less likely management actions that are invasive to wolves were acceptable and the more likely management actions that impact the individual were acceptable (Hypothesis 6).

Table G-1. Correlations of three emotion indices with acceptance of management actions for scenario one. ${ }^{a}$

\begin{tabular}{|c|c|c|c|}
\hline \multirow[b]{2}{*}{ Acceptability of management action ${ }^{\mathrm{C}}$} & \multicolumn{3}{|c|}{ Emotion indices $^{\mathrm{b}}$} \\
\hline & $\begin{array}{l}\text { Anger felt about } \\
\text { wolf presence }\end{array}$ & $\begin{array}{c}\text { Sympathy for } \\
\text { wolves }\end{array}$ & $\begin{array}{l}\text { Fear of } \\
\text { wolves }\end{array}$ \\
\hline Monitor the situation & $-.38 * *$ & $.34 * *$ & $-.26 * *$ \\
\hline Frighten the wolves away & $.15 * *$ & $-.09 * *$ & $.18 * *$ \\
\hline Capture and relocate the wolves involved & $.44 * *$ & $-.32 * *$ & $.41 * *$ \\
\hline Close only the section of the trail that the wolves are near & $-.38 * *$ & $.42 * *$ & $-.23 * *$ \\
\hline Close the entire trail until the wolves have left the area & $-.26 * *$ & $.34 * *$ & $-.11 * *$ \\
\hline
\end{tabular}

acenario 1 (Location: On a popular backcountry hiking trail in GRTE, Encounter: A hiker sees several wolves feeding on a dead deer close to the trail. The wolves seem reluctant to leave their kill, Status of the wolves: Listed as an endangered species, experimental population.)

${ }^{\mathrm{b}}$ Indices are comprised of various emotion items coded on a 5-point Likert-type scale ranging from 1 'strongly disagree' to 5 'strongly agree'. Cell entries represent bi-variate correlations: ** $p<.01$.

'Acceptance of management action coded on a 7-point Likert-type scale ranging from $1=$ 'highly unacceptable' to 7 = 'highly acceptable'.

Also, the two management options that were invasive to wolves (i.e., frighten the wolves away and capture and relocate the wolves involved) were positively correlated with the anger and fear indices (Hypothesis 7). Anger and fear towards wolves was negatively related to management actions that impact the individual - close the trail (Hypothesis 7). 
Table G-2. Correlations of three emotion indices with acceptance of management actions for scenario five. ${ }^{a}$

\begin{tabular}{lccc}
\hline & \multicolumn{3}{c}{ Emotion indices $^{\mathrm{b}}$} \\
\cline { 2 - 4 } Acceptability of management action $^{\mathrm{c}}$ & $\begin{array}{c}\text { Anger felt about } \\
\text { wolf presence }\end{array}$ & $\begin{array}{c}\text { Sympathy } \\
\text { for wolves }\end{array}$ & $\begin{array}{c}\text { Fear of } \\
\text { Wolves }\end{array}$ \\
\hline Monitor the situation & $-.33^{* *}$ & $.32^{* *}$ & $-.24^{* *}$ \\
Frighten the wolves away & $.11^{* *}$ & -.06 & $.14^{* *}$ \\
Capture and relocate the wolves involved & $.33^{* *}$ & $-.21^{* *}$ & $.33^{* *}$ \\
Close only the section of the trail that the wolves are near & $-.37^{* *}$ & $.41^{* *}$ & $-.24^{* *}$ \\
Close the entire trail until the wolves have left the area & $-.28^{* *}$ & $.36^{* *}$ & $-.13^{* *}$ \\
\hline
\end{tabular}

${ }^{a}$ Scenario 5 (Location: On a popular backcountry hiking trail in GRTE, Encounter: A hiker sees several wolves and their pups near what appears to be a denning site. As the hiker watches, the wolves become aware of the hiker's presence, Status of the wolves: Wolf numbers have increased; they are no longer listed as an endangered species.)

${ }^{\mathrm{b}}$ Indices are comprised of various emotion items coded on a 5-point Likert-type scale ranging from 1 'strongly disagree' to 5 'strongly agree'. Cell entries represent bi-variate correlations: ** $p<.01$.

'Acceptance of management action coded on a 7-point Likert-type scale ranging from 1 = 'highly unacceptable' to 7 = 'highly acceptable'. 


\section{Scenarios Involving Rancher-Wolf Conflicts (Scenarios Two, Three, and Six; Tables G-3, G-4, and G-5)}

For the relationship between sympathy for wolves and acceptability of management actions (Hypothesis 6), Scenarios 2 and 6 held the predicted relationship that sympathy for wolves would be positively related to management actions that were not invasive to wolves ('monitor the situation' and 'move' of 'remove the cattle'). Sympathy for wolves and acceptability of the one management action that was not invasive to wolves, 'monitor the situation' showed a positive correlation in Scenario 3. However, 'frighten the wolves away' showed typical to near-typical correlations with 'sympathy for the wolves' in Scenarios 3 \& 6. All correlations related to 'frighten the wolves away' showed less than minimal effects in Scenario 2. 'Capture and relocate the wolves involved' did not consistently follow the predicted pattern of 'invasive management actions.' However, the predicted negative correlation did show at substantial levels in all three scenarios for 'destroy the wolves involved.' Thus, the more sympathy for wolves the less destroying the wolves was acceptable, however other invasive management actions such as frightening and capturing were acceptable (Hypothesis 6 partially supported), perhaps to get the wolves out of harm's way.

Table G-3. Correlations of four emotion indices with acceptance of management actions for scenario two. ${ }^{a}$

\begin{tabular}{lcccc}
\hline & \multicolumn{4}{c}{ Emotion indices $^{\mathrm{b}}$} \\
\cline { 2 - 5 } Acceptability of management action $^{\mathrm{c}}$ & $\begin{array}{c}\text { Sympathy for } \\
\text { rancher }\end{array}$ & $\begin{array}{c}\text { Anger felt about } \\
\text { wolf presence }\end{array}$ & $\begin{array}{c}\text { Sympathy } \\
\text { for wolves }\end{array}$ & $\begin{array}{c}\text { Fear of } \\
\text { wolves }\end{array}$ \\
\hline Monitor the situation & $-.35^{* *}$ & $-.41^{* *}$ & $.38^{* *}$ & $-.27^{* *}$ \\
Frighten the wolves away & -.004 & $-.07^{*}$ & $.06^{*}$ & -.01 \\
Capture and relocate the wolves involved & $.36^{* *}$ & $.37^{* *}$ & $-.26^{* *}$ & $.32^{* *}$ \\
$\begin{array}{l}\text { Move the cattle to another area of the grazing } \\
\text { allotment }\end{array}$ & $-.53^{* *}$ & $-.56^{* *}$ & $.55^{* *}$ & $-.37^{* *}$ \\
Remove the cattle from the park & $-.57^{* *}$ & $-.58^{* *}$ & $.54^{* *}$ & $-.41^{* *}$ \\
Destroy the wolves involved & $.56^{* *}$ & $.69^{* *}$ & $-.64^{* *}$ & $.44^{* *}$ \\
\hline
\end{tabular}

acenario 2 (Location: Federal grazing allotment in GRTE, Encounter: A pack of wolves has been chasing cattle from a small herd from time to time over the past 2 weeks. The wolves have not killed any cattle, Status of the wolves: Listed as an endangered species, experimental population.)

${ }^{\mathrm{b}}$ Indices are comprised of various emotion items coded on a 5-point Likert-type scale ranging from 1 'strongly disagree' to 5 'strongly agree'. Cell entries represent bi-variate correlations:. * $p<.05 * * p<.01$.

${ }^{\mathrm{c}}$ Acceptance of management action coded on a 7-point Likert-type scale ranging from 1 = 'highly unacceptable' to $7=$ 'highly acceptable'. 
Table G-4. Correlations of four emotion indices with acceptance of management actions for scenario three. ${ }^{a}$

\begin{tabular}{lcccc}
\hline & \multicolumn{4}{c}{ Emotion indices $^{\mathrm{b}}$} \\
\cline { 2 - 5 } Acceptability of management action $^{\mathrm{c}}$ & $\begin{array}{c}\text { Sympathy for } \\
\text { rancher }\end{array}$ & $\begin{array}{c}\text { Anger felt about } \\
\text { wolf presence }\end{array}$ & $\begin{array}{c}\text { Sympathy } \\
\text { for wolves }\end{array}$ & $\begin{array}{c}\text { Fear of } \\
\text { wolves }\end{array}$ \\
\hline Monitor the situation & $-.41^{* *}$ & $-.47^{* *}$ & $.46^{* *}$ & $-.30^{* *}$ \\
Frighten the wolves away & $-.34^{* *}$ & $-.43^{* *}$ & $.40^{* *}$ & $-.26^{* *}$ \\
Capture and relocate the wolves involved & -.02 & $-.12^{* *}$ & $.17^{* *}$ & -.003 \\
Destroy the wolves involved & $.58^{* *}$ & $.70^{* *}$ & $-.73^{* *}$ & $.42^{* *}$ \\
\hline
\end{tabular}

acenario 3 (Location: On private ranch land next to GRTE, Encounter: A local rancher in the Jackson-Hole area has reported the loss of several cattle within the last month due to wolf kills, Status of the wolves: Listed as an endangered species, experimental population.)

${ }^{\mathrm{b}}$ Indices are comprised of various emotion items coded on a 5-point Likert-type scale ranging from 1 'strongly disagree' to 5 'strongly agree'. Cell entries represent bi-variate correlations: $* * p<.01$.

'Acceptance of management action coded on a 7-point Likert-type scale ranging from 1 = 'highly unacceptable' to $7=$ 'highly acceptable'.

Hypothesis 7 was not fully supported in any of the three rancher-wolf conflict scenarios. The management action of 'frighten the wolves away' was less than minimally related to any of the emotions in Scenario 2; minimally related in the other in-park Scenario 6, and typically correlated in the off-park Scenario 3. However, in Scenarios 2 and 6, anger and fear were positively correlated with 'capture and relocate the wolves involved.' Anger and fear of wolves were positively correlated with 'destroy the wolves involved.' Indeed, this specific management alternative emerges as predominant in the relationship between emotions and management actions. Relationships between emotions and "destroy the wolves involved" are close to or above the substantial relationship cut-off $(r=.5)$ in each interaction (negative for 'sympathy for wolves' $r=-.64$ to -.73; positive for 'sympathy for rancher,' 'anger about wolf presence,' and 'fear of wolves' $r=+.42$ to +.73 ). "Sympathy for the rancher," "anger about wolf presence" and "sympathy for wolves" all correlate as predicted, at substantial levels, with the management options of moving or removing the cattle in the in-park Scenarios 2 and 6 (Hypotheses 3 and 5). 
Table G-5. Correlations of four emotion indices with acceptance of management actions for scenario six. ${ }^{a}$

\begin{tabular}{lcccc}
\hline & \multicolumn{4}{c}{ Emotion indices $^{\mathrm{b}}$} \\
\cline { 2 - 5 } Acceptability of management action $^{\mathrm{c}}$ & $\begin{array}{c}\text { Sympathy for } \\
\text { rancher }\end{array}$ & $\begin{array}{c}\text { Anger felt about } \\
\text { wolf presence }\end{array}$ & $\begin{array}{c}\text { Sympathy } \\
\text { for wolves }\end{array}$ & $\begin{array}{c}\text { Fear of } \\
\text { wolves }\end{array}$ \\
\hline Monitor the situation & $-.41^{* *}$ & $-.46^{* *}$ & $.46^{* *}$ & $-.29^{*}$ \\
Frighten the wolves away & $-.18^{* *}$ & $-.27^{* *}$ & $.28^{* *}$ & $-.12^{* *}$ \\
Capture and relocate the wolves involved & $.12^{* *}$ & .04 & $.07^{*}$ & $.12^{* *}$ \\
Move the cattle to another area of the grazing & $-.55^{* *}$ & $-.58^{* *}$ & $.59^{* *}$ & $-.38^{* *}$ \\
allotment & $-.58^{* *}$ & $-.58^{* *}$ & $.57^{* *}$ & $-.41^{* *}$ \\
Remove the cattle from the park & $.61^{* *}$ & $.73^{* *}$ & $-.71^{* *}$ & $.45^{* *}$ \\
\hline Destroy the wolves involved & & & & \\
\hline
\end{tabular}

a Scenario 6 (Location: Federal grazing allotment in GRTE, Encounter: A cattle rancher has reported the loss of several cattle within the last month, killed by wolves, Status of the wolves: Wolf numbers have increased; they are no longer listed as an endangered species.)

${ }^{\mathrm{b}}$ Indices are comprised of various emotion items coded on a 5-point Likert-type scale ranging from 1 'strongly disagree' to 5 'strongly agree'. Cell entries represent bi-variate correlations: $* p<.05 * * p<.01$.

'Acceptance of management action coded on a 7-point Likert-type scale ranging from 1 = 'highly unacceptable' to $7=$ 'highly acceptable'. 


\section{Scenario Involving Pet Loss (Scenario Four; Table G-6)}

For the scenario depicting pet loss, Hypothesis 6 and 7 were partially supported (Hypothesis 8 was not tested for pet owners). The greater the sympathy for wolves, the more non-lethal management actions were acceptable, however non-lethal but invasive management actions had a positive relationship with sympathy for wolves (Hypothesis 6). One management option that was invasive to wolves, but did not involve destroying them (i.e., frighten the wolves away) was negatively correlated with the anger and fear indices (Hypothesis 7), but "capture and relocate the wolves involved" was not. However, the management action of destroying the wolves was substantially positively correlated with fear and anger, supporting Hypothesis 7.

Table G-6. Correlations of three emotion indices with acceptance of management actions for scenario four. ${ }^{a}$

\begin{tabular}{lccc}
\hline & \multicolumn{3}{c}{ Emotion indices $^{\mathrm{b}}$} \\
\cline { 2 - 4 } Acceptability of management action $^{\mathrm{c}}$ & $\begin{array}{c}\text { Anger felt about } \\
\text { wolf presence }\end{array}$ & $\begin{array}{c}\text { Sympathy for } \\
\text { wolves }\end{array}$ & $\begin{array}{c}\text { Fear of } \\
\text { wolves }\end{array}$ \\
\hline Monitor the situation & $-.50^{* *}$ & $.48^{* *}$ & $-.33^{* *}$ \\
Frighten the wolves away & $-.49^{* *}$ & $.47^{* *}$ & $-.29^{* *}$ \\
Capture and relocate the wolves involved & $-.16^{* *}$ & $.25^{* *}$ & -.02 \\
Destroy the wolves involved & $.71^{* *}$ & $-.69^{* *}$ & $.46^{* *}$ \\
\hline
\end{tabular}

acenario 4 (Location: On private land next to GRTE, Encounter: A homeowner has recently had their pet dog killed by a wolf. Status of the wolves: Wolf numbers have increased; they are no longer listed as an endangered species.)

${ }^{\mathrm{b}}$ Indices are comprised of various emotion items coded on a 5-point Likert-type scale ranging from 1 'strongly disagree' to 5 'strongly agree'. Cell entries represent bi-variate correlations. ** $p<.01$.

'Acceptance of management action coded on a 7-point Likert-type scale ranging from $1=$ 'highly unacceptable' to 7 = 'highly acceptable'. 